\title{
"Treading on the footprints of history": American Catholic Pilgrimage as Public History
}

\author{
Charlotte Vester \\ cfvester@mix.wvu.edu
}

Follow this and additional works at: https://researchrepository.wvu.edu/etd

Part of the Public History Commons

\section{Recommended Citation}

Vester, Charlotte, "'Treading on the footprints of history": American Catholic Pilgrimage as Public History" (2020). Graduate Theses, Dissertations, and Problem Reports. 7946.

https://researchrepository.wvu.edu/etd/7946

This Thesis is protected by copyright and/or related rights. It has been brought to you by the The Research Repository @ WVU with permission from the rights-holder(s). You are free to use this Thesis in any way that is permitted by the copyright and related rights legislation that applies to your use. For other uses you must obtain permission from the rights-holder(s) directly, unless additional rights are indicated by a Creative Commons license in the record and/ or on the work itself. This Thesis has been accepted for inclusion in WVU Graduate Theses, Dissertations, and Problem Reports collection by an authorized administrator of The Research Repository @ WVU. For more information, please contact researchrepository@mail.wvu.edu. 


\title{
"TREADING ON THE FOOTPRINTS OF HISTORY": American Catholic Pilgrimage as Public History
}

\author{
Charlotte Vester
}

Thesis submitted to the Eberly College of Arts and Sciences

at West Virginia University

in partial fulfillment of the requirements for the degree of

Master of Arts in

Public History

\author{
Melissa Bingmann, Ph.D., Chair \\ Elizabeth Fones-Wolf, Ph.D. \\ Jennifer Thornton, Ph.D. \\ Christopher Cantwell, Ph.D. \\ Department of History
}

Morgantown, West Virginia

2020

Keywords: Pilgrimage, Public History, Catholicism, American Catholics, Heritage Tourism, Intangible Heritage, Cultural Landscape, Historic Preservation 


\section{ABSTRACT \\ "Treading on the footprints of history": American Catholic Pilgrimage as Public History}

\section{Charlotte Vester}

In this thesis, I demonstrate how Catholic pilgrimage is a public history phenomenon. I define public history as public engagement, understanding, and use of the past. While I assert that pilgrimage is a public history phenomenon both in the past and in the present, my thesis will focus on American Catholic pilgrimage at the turn of the twentieth century. Each individual chapter will demonstrate that through pilgrimage, the faithful are engaged in public history in its various forms. Catholics actively took part in past-making and identity-construction in their roles as pilgrims. Through pilgrimage, Catholics were involved in the preservation and interpretation of tangible forms of heritage. On pilgrimage, pilgrims used intangible heritage practices to engage with cultural landscapes. Pilgrimage is a way of passing down tradition and knowledge, that sustains familial, community, and religious connections.

My research contributes to the genealogical literature of public history by pushing the roots of the discipline outside of the United States and back hundreds, if not thousands, of years. Public historians need to seriously consider pilgrimage as an origin of the field and as a site of inquiry. The secularization that came out of the Enlightenment and is inherent within the public history field in the United States strips sacred objects and places of particular histories and meaning. The discipline does the public a disservice by artificially cordoning off religion from historical interpretation and ignoring sites that are significant due to sacredness. Although the collaboration between religious groups and public history professionals may not be clear-cut or simple, it is a valuable partnership that can add nuance, complexity, and sensuality to historic interpretations of religious spaces. The alliance is sure to bear fruit for the pilgrim as well as the tourist. 


\section{ACKNOWLEDGMENTS}

This project has evolved and developed from its conception to its final product, and I would not have been able to complete it without the help of my family, my friends, and my professors. I want to thank my husband Gabriel for continually supporting me in all that I do. In the moments when this project seemed unbearably overwhelming, your love and encouragement kept me grounded and reminded me to take one step at a time. Thank you for sharing the load with me.

I want to thank my parents for teaching me to think for myself and showing me that I am capable of intellectual pursuit. I would not be the woman I am today without your devoted love and support, and I am eternally grateful. A special thank you to my father who suggested exploring this topic and shared sources, ideas, and advice. Thank you to my brother Ben for continually inspiring me to broaden the boundaries of my intellect. I am very fortunate to call you my brother.

I want to thank my oldest and dearest friend Alaine. Thank you for believing in me, cheering me on, and celebrating all that I accomplish. A large chunk of my writing took shape in your presence, during cherished study dates on sunny fall Saturdays. I want to thank my beloved friends Mara and Mary. Thank you for your constant prayers, kind words, and support from afar. I felt your presence keenly throughout this process, despite the long distance.

I want to thank all of my professors who pushed me to become a better scholar and helped transform my thesis from a series of discombobulated thoughts to a cohesive narrative. A special thanks to Dr Melissa Bingmann, Dr Elizabeth Fones-Wolf, Dr Jennifer Thornton, and Dr Christopher Cantwell, all who sat on my committee. You all informed my work in various ways that strengthened and enriched it. 
Finally, I would be remiss not to thank my Eternal Father who gave me an intellect to think, a will to act, and hands to write. Totus tuus. 


\section{CONTENTS}

$\begin{array}{ll}\text { ABSTRACT } & \text { ii }\end{array}$

$\begin{array}{lll}\text { ACKNOWLEDGMENTS } & \text { iii }\end{array}$

$\begin{array}{ll}\text { PROLOGUE } & 1\end{array}$

$\begin{array}{ll}\text { INTRODUCTION } & 6\end{array}$

Chapter One. The Stars and Stripes on Holy Ground: 27

American Catholic Pilgrimage at the Turn of the Twentieth Century

Chapter Two. Pious Preservation:

Safeguarding and Interpreting Tangible Heritage through Pilgrimage

Chapter Three. Worn Down by the Knees of Pilgrims:

102

Turn-of-the-Century Catholic Pilgrimage Practice as Intangible Heritage

EPILOGUE

BIBLIOGRAPHY 


\section{PROLOGUE}

On a chilly Friday afternoon in February, I interviewed Wanda Franz, a practicing Catholic living in Morgantown, West Virginia. She was born in 1944 into a Protestant family. Her father was in the army, and she spent several years of her childhood living in post-World War II Germany. Growing up, she attended a Sunday School associated with a Baptist church, and in her adolescence she was Episcopalian. She remembers traveling around Europe with her family as a child and admiring the many churches they visited. "I was really taken by the churches...I sometimes say that I became Catholic seeing the churches of Italy because I was so moved by how beautiful they were and that people who prayed there and worshipped there had to have something important." As she was preparing for her marriage to Gunter Franz (a Catholic), she converted to Catholicism. When asked about how she understands her Catholicism today, she responded, "It's just hard for me to separate my personality and my life and my activities...I mean everything is kind of a reflection of being Catholic."

Going on pilgrimage to the Holy Land is something that Wanda and her husband had been wanting to do for a while. When Gunter passed away in the fall of 2018, Wanda felt it was time to make the trip. "I had a sense of wanting to feel closer to Jesus and closer to the source of my faith and in that way also feeling closer to Gunter."

Wanda is a member of the Equestrian Order of the Knights of the Holy Sepulchre. The origins of the order are somewhat obscure, but the first documentary evidence dates back to 1336. Today, the order is a lay institution dedicated to aiding in the charitable, cultural, and social works of the Catholic Church in the Holy Land. A large portion of its members' donations 
go towards maintaining and preserving the historic Christian sites in Jerusalem and throughout the region. The pilgrimage that Wanda participated in was organized and led by the order.

According to Wanda, once one joins the Equestrian Order of the Knights of the Holy Sepulchre, it is encouraged that one embarks on pilgrimage to the Holy Land. Wanda was also very interested in seeing the archaeological sites she had read about for many years in biblical archaeology magazines. Before leaving on pilgrimage, she expected to be impressed.

The pilgrimage spanned ten days in total, with the first two days spent in Jordan visiting sites like Petra and a Christian mosaic-making factory, where they trained disabled people to make mosaics. The pilgrims then stayed three days in Galilee, and the rest of the trip they spent in Jerusalem. Father John, a Franciscan monk based out of Washington DC, served as their guide throughout the journey. At each site, he would begin by reading the relevant Bible passages associated with the site, he would then give the pilgrims historical context to situate the Bible scenes within contemporary life in Judea, and then he would give information on the site, such as when it was founded, some historical background, and some architectural interpretations. Pilgrims would then get some time to walk freely within the space (often a church).

The highlights of the pilgrimage for Wanda were participating in a solemn procession into the Church of the Holy Sepulchre, where she was able to touch the stone where Jesus had been prepared for burial, and walking along the Via Dolorosa holding a cross, as Jesus did as he marched to his crucifixion. In regard to the Via Dolorosa, Wanda explained that it was very meaningful to "be a part of that and know that this is where everybody walks on Holy Friday." The pilgrimage organizers paid for a local photographer to take pictures as the pilgrims took turns carrying the cross. That night, pilgrims had the opportunity to look at the shots and purchase them. "To me it's a service that I'm happy to pay for. To have the chance to do that, to 
walk with the cross but then, after that, to have pictures to commemorate it. I thought it was a worthwhile investment."

Half a dozen women in the group decided to opt out of walking along the Via Dolorosa, to do some afternoon shopping. This caused some tension within the party. Some members of the order had invited along relatives who were not Catholic, which surprised Wanda as she would have never considered inviting someone who was not of the faith. She explained that if she were not Catholic,

I would have not wanted to go on a pilgrimage. I would have wanted to go on just a tourist trip and visit museums and visit archaeological sites. I mean I can see doing that. That I could understand wanting to do, but to go on a pilgrimage, that's a completely different thing.

When asked about how she distinguished a pilgrim from a tourist, she said,

I think that a pilgrim is there to experience the sites and as being there in the presence of Jesus and to contribute to your spiritual betterment, you know. To be able to reflect on what Jesus had to say. To reflect on what he was doing at that particular site and what his message was. And if you're a tourist, you're looking at only at the beauty of the architecture, the geologic information that's there, the scenery. You're there to appreciate what's there but not necessarily to be reflecting on the spiritual insights that you could gain from being there in those sites.

As distinct as Wanda viewed the roles of pilgrim and tourist, she did not have any problems doing some shopping when she could. In fact, pilgrims seemed encouraged by the pilgrimage organizers to spend money. "The people who were on the pilgrimage really understood that they were expected to spend money, they were expected to buy things, they were expected to put money into the activities." More specifically, pilgrims tried to purchase goods from Christian vendors. "That was always for me a really important thing that they are Christians and not just Palestinians who have, you know, things to sell from Israel, but are really producing this themselves and that the money is going into the Christian community." However, Wanda explained, some situations made it difficult to not give business to Palestinian vendors. 
When we left this shop, all of these street vendors were standing out in front of the entrance to this shop. And they were saying look, they're Christians and that's fine, but we have to feed our families too. And they were trying to guilt us into buying stuff that they were selling... and I think we all bought stuff from them too, I mean I did. The idea was to make sure that you were helping to provide, you know, infuse the economy with American dollars.

Wanda bought some mosaics for her kids, some agate jewelry from street vendors, some rosaries that she touched to significant stones for special friends, and postcards from multiple sites. "I wanted to buy something tangible from the sites with stamps, so that my kids could have something, you know, that came from there."

Questions of authenticity also came up in Wanda's reflections. Wanda described some sites the pilgrims visited that were most likely not authentic, such as David's burial place in Jerusalem. "They have a spot in the old city where David supposedly was buried, but it doesn't jive with some of the stuff that was in the Old Testament....I mean the sites and all of that are correct, but some of the stories that have come down through the ages are conflicting. There are different things that have been told."

Another example Wanda gave is the upper room, where the resurrected Jesus allegedly presented himself to his disciples. Wanda described how the Romans, in a revolt in the year 70, completely destroyed the city, so all the buildings including the upper room were gone. According to Wanda,

they've identified the site where they believe that the upper room was, and in the Middle Ages they built something there and that's the room that people visit. I mean [the guide] explained all of that... some of the sites have been revered over the years as the site where it was and for that reason we continue to visit it and recognize it as the spot where it probably was, but the room itself is not particularly interesting.

The guide's interpretations also considered the layering of history, through the remains of religious structures from multiple historic periods within the walls of the modern churches. Because of the various religious groups that were in conflict in Jerusalem, churches were 
continually destroyed and rebuilt throughout history. In some churches, Wanda noted, the old parts were preserved and visible to visitors. In other locations, the guide would include interpretation of the layered historic structures in his discussion of the sites.

When reflecting on the pilgrimage once she got home, Wanda considered her role as a pilgrim.

I reflected more on just the fact that our, my presence in the Holy Land as a pilgrim had impacts on the people there. You know, the fact that we came, that we contributed to their economy. But that we also kind of demonstrated our appreciation for what they had, that it was important for them to, I think, in a way, to see how it's easy to take stuff for granted. That when people come and have a real appreciation for it, that it helps to give you more of a sense of appreciating it too.

Wanda's oral history reveals that pilgrims encounter questions about authenticity and layered histories. They give value to walking in the steps of pilgrims before them, connecting them to a shared past. They learn about Jerusalem's history and historical characters. They purchase objects and photographs to commemorate their journey and to share it with others. And they consider how their actions can benefit the local economy. However, they are also quick to distinguish themselves from the tourist, through their spiritual relationship with Jesus of Nazareth. 


\section{INTRODUCTION}

American Catholic pilgrimage is a phenomenon that took shape at the turn of the twentieth century. By the end of the nineteenth century, Americans pinned pilgrim badges to their overcoats while processing in foreign streets, proudly carrying the American flag. Catholic pilgrimage was not something new for the Church, as the devotional practice stretched back thousands of years. However, pilgrimage was new for American Catholics. Catholic newspapers and magazines published pilgrimage accounts from foreigners throughout the nineteenth century, and American Catholics eagerly consumed them. The printed words described sacred sites in Europe, Central America, and the Holy Land. They delighted in the miracles that placed these shrines on the map and the pious atmosphere the holy sites cultivated. Through pilgrimage literature published from 1885 to 1918 , the beginning of American Catholic pilgrimage reveals itself to illustrate how the faithful in the United States incorporated these pious journeys within their devotional practices. Further, pilgrimage literature exposes how American Catholics understood and documented pilgrimage. American Catholics used pilgrimage to forge a Catholic identity for themselves in Protestant America and to construct an American identity for themselves within the universal Church. They were able to do so through the history they encountered while on their religious journey.

At the turn of the century, pilgrims were not only going to shrines but were also visiting some unexpected sites. In Amalfi, Italy, a vacant Capuchin monastery offered pilgrims the opportunity to sleep in monk cells and dine in the old white-washed chapel. ${ }^{1}$ The activity was an immersive experience attractive to the religious tourist rather than the pilgrim traveling to a destination designated as sacred. In Paray-le-Monial, France, a group of laymen founded a

\footnotetext{
${ }^{1}$ The Sacred Heart Review, July 28, 1894. Hereafter cited as Sacred Heart.
} 
Eucharistic museum. Catholic pilgrimages had not traditionally included visits to museums focused on a sacred subject, but a group of faithful laymen took a cue from secular institutions and conformed it for the Church.

In 1895, a Catholic society was in the process of restoring the ancient church of $\mathrm{St}$ Francis of Sales and the former home of the saint in Annecy, France. The society had already created a small museum of relics open for the visits of pilgrims, and they were calling for pieces of seventeenth-century furniture to furnish the saint's humble abode. ${ }^{2}$ The establishment of a museum of relics creates an interesting tension between pilgrimage and tourism. Relics were often the reason for pilgrimage and were to be blessed and adored, but museums were not the appropriate locale for prayer and adoration. Traditionally, museums were a site where one gained knowledge or examined curiosities, the destination of tourists. A museum of relics places these dichotomies within the same space, complicating its status as either a pilgrimage site or a tourist destination. Additionally, the attempt the Catholic society made to furnish the saint's home with period pieces in preparation for pilgrims, transformed the dwelling into a house museum, again blurring the distinction between pilgrimage and tourism.

The tension between pilgrimage and tourism is a topic that still garners much attention from scholars today. However, pilgrimage has never been considered a public history phenomenon. Pilgrimage is an activity that encourages participation from the general public. Through pilgrimage, the public is enveloped in various histories, whether religious or secular, and art histories, as the pilgrimage often integrates architecture and artworks. The interdisciplinary nature of pilgrimage seems not to have been explored, even though it is a rich and flexible topic. I focus on religious journeys in my own research, but the topic is likewise

\footnotetext{
2 “General Foreign Notes," Sacred Heart, January 26, 1895.
} 
open to secular pilgrimage. In my thesis, I will demonstrate how Catholic pilgrimage, both in the past and today, is a public history phenomenon. When on pilgrimage, pilgrims are actively engaged in shaping historical narratives.

My research seeks to prove this fact by understanding when American Catholics began going on pilgrimage, where they were going, what they were doing, and how they were talking about it. I investigated The Sacred Heart Review, a weekly Catholic newspaper published in Boston that ran from 1888 to 1918, analyzing all articles with mention of pilgrimage. I studied other contemporary articles, pilgrim accounts, pilgrimage manuals, and pamphlets to supplement The Sacred Heart Review, including an account of the first American Catholic pilgrimage to the Holy Land. Additionally, I examined the material culture used on pilgrimage from the time period to uncover what it revealed about pilgrimage practices and the construction of identity. Because my research focused primarily on a single newspaper, my analysis is geographically based in Boston. Diving into Catholic literature published in other areas of the United States to understand whether or not American Catholics as a whole were conceptualizing, writing about, and participating in similar pilgrimages during the period, would be an interesting line of inquiry for future research.

Examining the price of the newspapers, periodicals, and pamphlets I've analyzed establishes that the audience reading these sources varied greatly in economic status, ranging from lower class to upper class (varying from 5 cents to \$2). ${ }^{3}$ An advertisement for Edward Dunigan \& Brother (New York), a press that published ephemera associated with pilgrimage, demonstrates this well as it stated that "the publisher's prices vary from 12.5 cents to $\$ 9$

\footnotetext{
${ }^{3}$ Sacred Heart, 5 cents; "A Shrine in the Mohawk Valley" pamphlet, 10 cents; "Our Lady of Martyrs: Auriesville, NY" pamphlet published as part of an illustrated semi-monthly magazine in Philadelphia, \$2 a year; "Devotion to the Miraculous Infant Jesus of Prague" pamphlet, $\$ 1$ for set of leaflets.
} 
according to illustrations and bindings." ${ }^{4}$ However, inspecting the advertisements found in these sources, it appears that the target audience was the rising, financially conscious upper-middle class. An ad for a general store proclaimed that its merchandise "is at prices that are the lowest possible goods of the same standard of excellence and merit," and another ad for parlor furniture, chamber furniture, dining room furniture, and carpets (goods only attainable for financially secure clientele) announced that they were "at prices that can't be beat." 5 The rising middle class would have desired displaying quality goods within their home to exhibit their economic status, but they would have also been concerned with the cost of such things. ${ }^{6}$ American Catholics of the lower class were exposed to pilgrimage literature, but American Catholics of the upper and middle class had the financial resources to partake in pilgrimage. Therefore when I refer to "American Catholics" within my thesis, I am referring primarily to those of the upper and middle class.

There has not been much scholarly work done on American Catholic pilgrimage within the United States or abroad. The topic of pilgrimage has enjoyed much scholarly attention in several fields, and the experience of American Catholics has also been a topic of research, but few scholars have studied the pilgrimage journeys of American Catholics to holy sites at the turn of the century. This research will bridge the gap in the literature on American Catholics and Catholic pilgrimage, as well as contribute to a growing interest in analyzing and questioning the differences and similarities between pilgrimage and tourism.

There have been a couple of articles published on American Catholic pilgrimage. David

\footnotetext{
${ }^{4}$ Exercises of the Way of the Cross, as it is Performed at Jerusalem, and in the Colosseum at Rome (New York: Edward Dunigan \& Brothers, 1855).

${ }^{5}$ Cathedral Sanctuary Society, Souvenir of the Golden Jubilee and Solemn Consecration of the Cathedral of the Immaculate Conception, 1852-1902 (Albany: Argus Co, 1902), 87; Sacred Heart, May 4, 1889, 10.

${ }^{6}$ Jay P. Dolan, The American Catholic Experience: A History from Colonial Times to the Present (Westminster: Crown Publishing Co, 2011), 147.
} 
Klatzker published “American Catholic Travelers to the Holy Land 1861-1929” in The Catholic

Historical Review in 1988. In his article, Klatzker outlined the history of pilgrimages to the Holy Land in light of the values and religious sensibility of American Catholics, the organizational inclination of the American Church, and the dynamics of Catholic-Protestant and CatholicJewish relations. ${ }^{7}$ Robert Orsi examined Catholic pilgrimage within the United States in his article "The Center out There, in Here, and Everywhere Else: The Nature of Pilgrimage to the Shrine of Saint Jude, 1929-1965," published in Journal of Social History in 1991. Orsi used the Shrine of Saint Jude in Chicago to argue that American Catholic devotion experienced a spatial shift from the local to the national in the 1920s and then from space (praying collectively at a certain shrine) to time (praying collectively at a certain time) by the $1930 \mathrm{~s}^{8}$

At the end of the twentieth century, scholars became interested in exploring the experience of Catholics throughout American history. James Hennesey's American Catholics: A History of the Roman Catholic Community in the United States asserted that the history of Catholicism in the United States breaks into three distinct periods: the "American period" from 1634 to 1829 , the immigrant period starting in the 1830 s, and a period of centralization and uniformity by the end of the nineteenth century. ${ }^{9}$ In The American Catholic Experience, Jay P. Dolan analyzed the continuing problem of Catholics attempting to determine their relationship to social, political, and cultural life in the United States. Dolan spent a great amount of attention on the immigrant Church between 1820-1920, and he explored the tension between immigrants' desire to preserve their culture and the pressure to become American as quickly as possible. ${ }^{10}$

\footnotetext{
${ }^{7}$ David Klatzker, "American Catholic Travelers to the Holy Land 1861-1929," The Catholic historical review 74, no. 1 (1988): 55-74.

${ }^{8}$ Robert Orsi, "The Center Out There, In Here, and Everywhere Else: The Nature of Pilgrimage to the Shrine of Saint Jude, 1929-1965," Journal of Social History (1991): 213-232.

9 James J. Hennesey, American Catholics: A History of the Roman Catholic Community in the United States (Oxford: Oxford University Press, 1983).

${ }^{10}$ Dolan, The American Catholic Experience.
} 
The Household of Faith: Roman Catholic Devotions in Mid-Nineteenth Century America by Ann Taves explored how the everyday spiritual life of the Catholic laity illuminated their fears and beliefs. She argued that the Roman Catholic Church appropriated locally-based devotional practices for use by the entire Church to ensure that popular piety would not overshadow the central sacraments. ${ }^{11}$ In Catholic Immigrants in America, James S. Olson outlined the experience of immigrant Catholics in the United States through the themes of ethnic diversity, modernization of economic and social life, acculturation to American values, and struggles with nativism. ${ }^{12}$ Catholicism and the Shaping of Nineteenth-Century America by Jon Gjerde sought to bring Catholic and Protestant historical scholarship in conversation with one another. He argued that the history of anti-Catholicism reflects how religious conflict built the nation and demonstrates the tight relationship between religion and national identity within immigration history. ${ }^{13}$

Christian pilgrimage has been a topic of study in a wide range of fields spanning from history and geography to anthropology and theology. Image and Pilgrimage in Christian Culture: Anthropological Perspectives by Victor and Edith Turner is a foundational work that is often cited within the literature. The Turners asserted that pilgrimage is a "liminoid" phenomenon, meaning it creates its own dynamic outside of the normal social and religious structures of Catholicism through the formation of "communitas" which embody new social structures. ${ }^{14}$ In 1989, Mary Lee and Sidney Nolan, two geographers, wrote Christian Pilgrimage in Modern Western Europe. The work analyzed modern European pilgrimage between 1780 and

\footnotetext{
${ }^{11}$ Ann Taves, The Household of Faith: Roman Catholic Devotions in Mid-Nineteenth Century America (Charlottesville: University Press of Virginia, 1986).

12 James Stuart Olson, Catholic Immigrants in America (Chicago: Nelson-Hall, 1987).

${ }^{13}$ Jon Gjerde, Catholicism and the Shaping of Nineteenth-Century America (Cambridge: Cambridge University Press, 2011).

${ }^{14}$ Victor Turner and Edith Turner, Image and Pilgrimage in Christian Culture: Anthropological Perspectives (New York: Columbia University, 1978).
} 
1980 and surveyed 6,150 shrines in sixteen western European countries. The authors did not offer a particular argument, but rather cross-tabulated different categories of data that may be useful for historians. ${ }^{15}$ Contesting the Sacred: The Anthropology of Christian Pilgrimage edited by John Eade and Michael Sallnow presented pilgrimage as a site of conflicting discourses and interpretations, as players competed for cultural resources. ${ }^{16}$ In New Pathways in Pilgrimage Studies: Global Perspectives, John Eade and Dionigi Albera examined research undertaken outside the Anglophone world, encouraging scholars to consider how colonial influences, secular nationalism, tourism, and religious reformism are shaping pilgrimage practices.

Intersecting Journeys: The Anthropology of Pilgrimage and Tourism edited by Ellen

Badone and Sharon R. Roseman questioned the distinctions between "tourist" and "pilgrim."17 Noga Collins-Kreiner examined the pilgrim as tourist as well in her article, "The Geography of Pilgrimage and Tourism: Transformations and Implications for Applied Geography" in Applied Geography. She explored Christian, Jewish, Baha'i, and Buddhist pilgrimage and concluded that during the twentieth century the division between pilgrimage and tourism tended to blur. ${ }^{18}$ Doron Bar and Kobi Cohen-Hattab argued in their article "A New Kind of Pilgrimage: The Modern Tourist Pilgrim of Nineteenth-Century and Twentieth-Century Palestine" that the modern tourist pilgrim emerged in turn-of-the-century pilgrimages to the Holy Land. They posited that modern tourist pilgrims were "as a rule members of the Protestant denomination" and traditional pilgrims

\footnotetext{
${ }^{15}$ Mary Lee Nolan and Sidney Nolan, Christian Pilgrimage in Modern Western Europe (Chapel Hill: University of North Carolina Press, 2018).

${ }^{16}$ John Eade and Michael J. Sallnow, eds. Contesting the Sacred: The Anthropology of Pilgrimage (Champaign: University of Illinois Press, 2000).

${ }^{17}$ Ellen Badone, ed. Intersecting Journeys: The Anthropology of Pilgrimage and Tourism (Champaign: University of Illinois Press, 2010).

${ }^{18}$ Noga Collins-Kreiner, "The Geography of Pilgrimage and Tourism: Transformations and Implications for Applied Geography," Applied Geography 30, no. 1 (2010): 153-164.
} 
were mostly Catholic and Orthodox Christians. ${ }^{19}$ My thesis will suggest that the muddied division between pilgrim and tourist was present within Catholic pilgrimage as well.

In Religion and Tourism: Crossroads, Destinations and Encounters, Michael Stausberg put together the first monograph compiling works from different disciplines focused on the intersection between religion and tourism. He posited that tourism is a major arena, context, and medium for religion in the contemporary global world. William H. Swatos argued that tourism literature has unduly minimized the religious motivation within pilgrimage, in On the Road and Being There: Studies in Pilgrimage and Tourism in Late Modernity. What is important when analyzing pilgrimage, Swatos asserted, is to appreciate a pilgrim's intention. My research will build on Swatos's argument that a pilgrim's stated intention is significant and must be considered within analysis.

Additionally, scholars have spent time analyzing pilgrimage sites within the United States. Thomas S. Bremer studied San Antonio's former missions in Blessed with Tourists: The Borderlands of Religion and Tourism in San Antonio. He argued that religious adherents have much in common with tourists and that through producing and maintaining religious spaces, one is involved in the articulation of identities. In "The Interweaving of Pilgrimage and Tourism at the Santuario de Chimayó," Brett Hendrickson explained that the changing economic and ethnic context of northern New Mexico resulted in the increased volume of visitors to the shrine. He advanced that "Hispanic village life—including religious life—-has become fodder for the burgeoning tourist industry." 20

\footnotetext{
${ }^{19}$ Doron Bar and Kobi Cohen-Hattab, "A New Kind of Pilgrimage: The Modern Tourist Pilgrim of NineteenthCentury and Early Twentieth-Century Palestine," Middle Eastern Studies 39, no. 2 (April 2003): 137, doi:10.1080/714004511.

${ }^{20}$ Brett Hendrickson, "The Interweaving of Pilgrimage and Tourism at the Santuario de Chimayó," US Catholic Historian 34, no. 3 (Summer 2016): 129.
} 
My thesis will not only focus on pilgrimage sites, but rather the pilgrimage journey as a whole. In Walking Where Jesus Walked, Hillary Kaell has written the most recent and comprehensive work on contemporary Christian pilgrimage to the Holy Land, where she suggested that pilgrimage is spiritually powerful because of the juxtaposition of religion with tourism and commercialism. According to Kaell, the experience of pilgrimage extends to before and after the physical journey. Joerg Rieger asserted the importance of travel within the Jewish and Christian faith tradition in Faith on the Road: A Short Theology of Travel and Justice. Rieger proposed that Christianity is "a matter of the road," as Jesus's life and ministry was centered on movement. John Eade and Simon Coleman emphasized the importance of movement within pilgrimage as well. In Reframing Pilgrimage: Cultures in Motion, Eade and Coleman presented pilgrimage as "kinetic rituals" in which the movement to and movement within sites can help construct sacred spaces.

Religious objects and sites have been object of study within the fields of museum studies, heritage studies, and performance studies. These various fields can be understood as elements of public history practice, particularly when considered in conjunction. My research will assert that pilgrimage is a valuable site of inquiry for public historians, placing it in dialogue with what scholars have written on the intersection of religion and the public's use of the past.

There has been a growing interest within museum studies to contextualize religious objects on display. In Religious Objects in Museums: Private Lives and Public Duties, Crispin Paine aimed to review how museums handle religion and religious objects. According to Paine, religious objects should "help the museum visitor see the object through the eyes of the devotee" and "meet the demands of all those people who feel that the object is personally important to 
them." ${ }^{21}$ Bruce M. Sullivan edited a collection that explored and problematized the idea that objects in museum collections can be regarded as sacred, as all sacred qualities are removed when an object is exhibited. ${ }^{22}$ In Religion in Museums: Global and Multidisciplinary Perspectives, contributors presented the important role museums play among religious studies scholars and how museums are treating and interpreting religious artifacts. Interpreting Religion at Museums and Historic Sites, edited by Gretchen Buggeln and Barbara Franco, insisted that religious identity is an important component of the past that is often ignored in historical narratives. By listening to both religious communities and scholarly voices, exhibits will provide complex and nuanced interpretations, an assertion I will support in my thesis.

My research will build on scholarly works within heritage studies. Brian Graham and Peter Howard analyzed the interconnections between heritage and identity in The Ashgate Companion to Heritage and Identity. They argued that heritage has little intrinsic worth, but rather people place values on objects or places, which then inform their perceived identity. The construction of identity, both national and religious, through heritage experienced on pilgrimage is an argument I will put forth.

In "Experiencing Authenticity at Heritage Sites: Some Implications for Heritage Management and Conservation," Siân Jones encouraged a break from the prevailing dichotomy between materialist approaches and constructivist approaches to authenticity. Instead, people experience authenticity through a network of relationships between objects, people, and places. Siân Jones later wrote an article with Sally M. Foster, in which they argued that replicas have

\footnotetext{
${ }^{21}$ Crispin Paine, Religious Objects in Museums: Private Lives and Public Duties (New York and London: Bloomsbury Publishing, 2013), 20, 21.

${ }^{22}$ Bruce M. Sullivan, ed., Sacred Objects in Secular Spaces: Exhibiting Asian Religions in Museums (New York and London: Bloomsbury Publishing, 2015).
} 
untold heritage value and can be perceived as authentic in their own right. ${ }^{23}$ Discussions regarding "true pilgrimage" at the turn of the century will contribute to this literature.

Scholars have explored religious sites from a heritage studies perspective. In "Caminoisation and Cathedrals: Replication, the Heritagisation of Religion, and the Spiritualisation of Heritage," Marion Bowman and Tiina Sepp drew on fieldwork and argued that pilgrimage routes and sites are transforming into heritage sites, as pilgrims attempt to connect to a lost history. Contributors of Everyday Sacred: Religion in Contemporary Quebec approached religion as a densely textured complex of beliefs, practices, and relationships that are historically emplaced. They maintained that religion operates on multiple levels, whether institutionalized or not, both discursive and embodied.

Studies investigating intangible heritage and performance studies are important to consider when analyzing pilgrimage practices. In The Semiotics of Heritage Tourism, Emma Waterton and Steven Watson suggested that a richer understanding of heritage tourism would include the sensual, emotive, and embodied aspects of heritage tourist experiences. Performance studies scholar Diana Taylor has made a case for "the repertoire," or acts of embodied memory including performance, gestures, orality, and movement, as nonreproducible knowledge that is just as significant as traditional forms of knowledge production. ${ }^{24}$ Claire Sponsler used the idea that embodied acts and performances can act as a connection to the past in Ritual Imports:

Performing Medieval Drama in America. However, Sponsler asserted that these rituals have a "distinctive historicity in which the interplay between past and present is of fundamental importance."

\footnotetext{
${ }^{23}$ Sally M. Foster and Siân Jones, "The Untold Heritage Value and Significance of Replicas," Conservation \& Management of Archaeological Sites 21, no. 1 (February 2019): 1-24, doi:10.1080/13505033.2019.1588008.

${ }^{24}$ Diana Taylor, The Archive and the Repertoire: Performing Cultural Memory in the Americas (Durham and London: Duke University Press, 2003).
} 
My research will connect these varied disciplines and the disparate lines of inquiry that scholars have followed relating to pilgrimage, heritage, and history. Historian Robert A. Orsi has pushed back against the modern liberal notions of religion as an autonomous, distinct domain apart from other areas of life. He proposed that

the presence of the gods and humans to each other in the varied spaces of their interactions with all the practices and things such encounters generated has to become the domain of critical theory, too, and of history. We can talk of the spaces and times of shrines and pilgrimages, of the circulation of ritual objects, and so on, but we have probably talked enough about all this now. Further theorizing along these lines is simply deflecting attention from the challenge of understanding how people meet their gods and how their gods meet them, how humans and their gods make their ways together through the challenges and excitements of life, how the gods become dwellers in this same modern history, independently of their human counterparts, and what they get up to, and what all this means for the social, political, and psychological life of the contemporary world..$^{25}$

American Catholics at the turn of the twentieth century wanted sacred spaces to be reckoned

with. Henry F. Brownson illuminates this fact in his pamphlet "The Proof of Miracles,"

published in 1898.

If miracles are possible, if we can presume nothing against their actually being wrought, and if what in regard to them requires to be proved is as easily and as certainly ascertainable, and as susceptible in its nature of proof, as the ordinary facts of history, it must be conceded that the proof which suffices to prove the ordinary facts of history is all that is needed for them, and we are unreasonable when we demand more. It is not true, then, that reason demands extraordinary proof in the case of the miracles, and that we can not prudently assent to them unless they are sustained by more than the ordinary degree of historical evidence. ${ }^{26}$

I will follow Orsi's lead by recognizing pilgrims' desires to experience a historical past interwoven with spiritual encounter. By doing so, I hope to uncover meaning that has been previously overlooked.

\footnotetext{
${ }^{25}$ Robert A. Orsi, “Abundant History,” Historically Speaking 9, no. 7 (September/October 2008), 14.

${ }^{26}$ Henry F. Brownson, "The Proof of Miracles," 1898, Ave Maria Box, BT97.B8, The Catholic University of America, The American Catholic History Research Center and University Archives, Washington, DC, 7-8.
} 
The term pilgrimage is now commonly used to denote journeys of all kinds, both religious and secular. In modern times it has become increasingly more difficult to distinguish the "pilgrim" from the "tourist." At the turn of the century, Catholics defined pilgrimage as a religious journey, often to a shrine or sacred site, by which the faithful grew closer to God through penance, devotions, and acts of homage. To arrive at the destination was not the ultimate goal, but rather the purpose of pilgrimage was "sanctification of the pilgrims or some religious improvement." ${ }^{27}$ Additionally, many sites of pilgrimage had indulgences associated with them, a Catholic doctrine that promised remission of temporal or purgatorial punishment upon reception. ${ }^{28}$ The elements that were necessary to consider a journey a pilgrimage was a source of tension that my thesis will address. However, a pilgrim will be generally defined as an individual who partakes in a religious journey with the intention of increasing in holiness whether through devotional acts, spiritual reflection, or the gaining of indulgences.

Pilgrimage has played a significant role within countless religions. Catholic pilgrimage dates back to the early Church, as Christians wished to travel to locales where their Savior, His Blessed Mother, and His disciples once trod. Pilgrims, dressed in penitential garb, used their journeys as acts of penance in the first centuries, and pilgrimage quickly became a form of popular devotion. By the Middle Ages, the Church had organized infrastructure to accommodate traveling pilgrims including hospices, roads, and troops to protect them. Pilgrimage sites expanded from journeys to the Holy Land to trips to Rome. Shrines developed, as members of the faithful reported apparitions of the Virgin Mary and the clergy placed the human remains of saints, considered relics, in various churches. Pilgrimage's popularity endured throughout the

\footnotetext{
27 “The Most Successful Protestant Pilgrimage," Sacred Heart, August 8, 1896.

${ }^{28}$ Purgatory is a Catholic doctrine that is defined as the purification that takes place between earthly life and heaven. See the Catechism of the Catholic Church, 1030.
} 
ages, into the nineteenth century, and on to today.

Public historians have had difficulty providing a unified definition of public history that incorporates the many subfields within the discipline. Museum studies scholar Lara Kelland has described public history as "the professional umbrella term that has emerged to encapsulate museum work, historic preservation, oral history, archival work, material culture conservation, digital history, and many other deployments of the past in public venues." ${ }^{29}$ Heritage specialist Harold Kalman defines public history as “'“applied history,' practiced in public agencies and private contexts outside the academic arena." He goes on to state that "a key objective of public history is that the results should be 'accessible and useful to the public." 30 The Public Historian has stated "that [public history] involves historical research, analysis and presentation with some degree of explicit application to the needs of contemporary life." 31 Public historians David Trask and Robert Pomeroy III have argued that public history "is an ancient approach to the study of past processes in settings elsewhere than in educational institutions." 32 Public historian Thomas Cauvin defines it "as being based on three particular emphases: the communication of history to non-academic audiences, a public participation, and the application of historical methodology to present-day issues." ${ }^{33}$ My definition of public history is public engagement, understanding, and use of the past.

Public historians have recently been asking questions about the origin of the field. Public history was not created because of the academic job crisis of the 1970s. Simply because academics formed a public history field does not mean that public engagement with the past was

\footnotetext{
${ }^{29}$ Lara Kelland, Clio's Foot Soldiers: Twentieth-Century US Social Movements and Collective Memory (Amherst: University of Massachusetts Press, 2018), 4.

${ }^{30}$ Harold Kalman, Heritage Planning: Principles and Process (New York: Routledge, 2014), 181.

${ }^{31}$ Hilda Kean and Paul Martin, eds., The Public History Reader (New York: Routledge, 2013), xiv.

32 Ibid., xvii.

${ }^{33}$ Thomas Cauvin, "The Rise of Public History: An International Perspective," Historia Crítica 68, no. 68 (2018): 4.
} 
not going on beforehand. In Clio's Foot Soldiers: Twentieth-Century US Social Movements and Collective Memory, Lara Kelland proposed that activists during the 1960s, 1970s, and 1980s were using history for cultural and political aims by tying their activism to historical narratives, creating archives, developing interpretive projects, and transmitting historical education. On the other hand, the preservation of buildings undertaken by women's voluntary societies in the midnineteenth century, the creation of local historical societies in the late nineteenth century, and the creation of the National Park Service in the 1930s have all been offered as possible origins of the field, or as examples of public history long before the academic discipline. ${ }^{34}$ Denise D. Meringolo pushed the roots of public history back to the mid-nineteenth century, as history became important to the federal government due to a desire to protect landscapes and artifacts for the public. ${ }^{35}$ The timeline has still not been pushed back far enough. There are examples of public history that are much older and that did not emerge in the United States.

Studying Catholic pilgrimage contributes to the genealogy of public history, as pilgrimage was a way by which Catholics were actively engaged in history for thousands of years. It has been ignored by public historians because of its grassroots nature. Academics had no hand in this engagement with the past, but rather pilgrims cared about their history and actively shaped historical narratives through pilgrimage. In The Presence of the Past, Roy Rosenzweig and David Thelen discovered that public audiences view engagement with the past as something that is active, social, and helps people understand who they are as they connect with family and community. Audiences desire to encounter history in a way in which they are actively engaged. On pilgrimage, Catholics use religious history to make shrines or historic

\footnotetext{
34 Denise D. Meringolo, Museums, Monuments, and National Parks: Toward a New Genealogy of Public History (Amherst: University of Massachusetts Press, 2012), xiv.

35 Ibid.
} 
churches applicable to their life today. By doing so, they are actively partaking in past-making and identity-construction, inserting themselves in the same historical narratives established hundreds or thousands of years before. Pilgrimage is a way of passing down tradition and knowledge, that sustains familial, community, and religious connections. Chants, songs, prayers, and material culture used on pilgrimage are a collective memory practice.

In his foundational work Interpreting our Heritage, Freeman Tilden encouraged interpreters to touch the visitor's “personal experience, thoughts, hopes, way of life, social position, or whatever else. ${ }^{\prime 36}$ On pilgrimage, the faithful encounter material culture, architecture, and art that inspires them to place themselves in the past. They envision historic scenes as they participate in embodied acts of memory, and they imagine the pilgrims who have come before them throughout the centuries as they gaze upon the cultural landscape of Rome and Jerusalem. Public historians often remark that history is not about the past, but rather it must inform the present and the future. Pilgrimage does just that. Through pilgrimage, pilgrims use the history they encounter during their religious journey to transform their spiritual lives in the present day.

Pilgrims actively engage in the past in many different ways. Pilgrimage is chock-full of embodied acts of memory, what UNESCO calls intangible heritage, including genuflection, prostration, chanting, kneeling, and touching/kissing relics. These movements were passed down from pilgrims throughout the millennia engaging in the same actions at the same site. Several events associated with Catholic pilgrimage practices have already been inscribed in UNESCO's Intangible Heritage list. They include processions such as the Holy Week processions in Mendrisio, Switzerland; the festival of the Santísima Trinidad del Señor Jesús del Gran Poder in La Paz, Bolivia; the festivity of Virgen de la Candelaria in Puno, Peru; the Círio de Nazaré in

\footnotetext{
${ }^{36}$ Freeman Tilden, Interpreting our Heritage (Chapel Hill: The University of North Caroline Press, 2009), 38.
} 
Belém, Brazil; the festivity of Saint Blaise in Dubrovnik, Croatia; the Holy Week processions in Popayán, Columbia; the procession of the Holy Blood in Bruges; the hopping procession in Echternach, Luxemburg; as well as passion plays such as the Škofja Loka passion play in Škofja Loka, Slovenia. Some pilgrimages are even inscribed, such as the celebration in honor of the Budslaŭ icon of Our Lady in Budslaŭ village, Belarus and La Romería (the pilgrimage) of the Virgin of Zapopan in Zapopan, Mexico. ${ }^{37}$

Catholics have actively preserved historic structures. Pilgrimage has resulted in historic preservation for centuries, through the maintenance of pilgrimage sites. The institutional Church has preserved historic structures associated with sacred events, such as the Cathedral of Santiago de Compostela (twelfth century) and the Basilica of Our Lady of Copacabana (sixteenth century), as have local communities with sites such as Maria Taferl Basilica (seventeenth century) and the Shrine of Our Lady of Kevelaer (seventeenth century).

Both pilgrimage sites and pilgrimage routes should be recognized as cultural landscapes. Cultural landscapes are "extended landscapes with features that have been shaped by human use," including both material (buildings, statues, grottos) and non-material (events, activities, performances, emotions). ${ }^{38}$ Just as with cultural landscapes, pilgrimage and its practices are place-based and are sites where pilgrims can participate in the formation of historical narratives. Through pilgrimage practices, both the built environment and the historical events associated with the place are preserved and passed down for future generations.

Like museums, pilgrimage sites have large collections of material culture, as Catholic pilgrims journey to encounter objects associated with holy figures. In Presence of the Past, Thelen and Rosenzweig uncovered that public audiences trust historical artifacts as sources of

\footnotetext{
${ }^{37}$ All of these listing can be found at https://ich.unesco.org/en.

${ }^{38}$ Kalman, Heritage Planning, 14.
} 
historical truths. Museums have recently recognized the ability of material culture to connect visitors to those who left little behind, but pilgrims have understood this fact far before the advent of the museum. Much like an exhibit, pilgrimage has an inherent historical narrative. Whether the journey traces the road Jesus, his disciples, or the saints walked, the itinerary is made coherent by following a historical past.

Pilgrims choose how to explore a pilgrimage site, and they do so at their own pace. The artwork found at the cathedrals, churches, and shrines is meant to educate the viewer on biblical stories, saints' lives, or theological issues. At one time, visual culture was the best way to educate a mostly illiterate population, and the frescoes, paintings, and sculptures continue to impart knowledge of past events. These artworks allow for pilgrims to undertake a kind of "selfguided" tour, when visiting a site without a guide.

Pilgrimage shrines mirror exhibits. The interaction between material culture, sound, and scent creates meaning. Mary Nooter Roberts has pointed out that "when devotees and/or practitioners build shrines, they select items to stand for greater wholes, and recombine them in ways that augment and transform their meanings, just as exhibitions do." 39 As museum curators search for creative solutions to forge emotive experiences for visitors, shrine directors note that Catholic pilgrimage destinations have always offered such experiences to pilgrims. ${ }^{40}$

Curators have been concerned about the "mummification" of living memories when objects are placed in an exhibit. At pilgrimage shrines this mummification is avoided, as interpretation and meaning are more malleable and pilgrims have more agency. Heritage scholar Christina Kreps has proposed that priests, ritual specialists, and shamans are curators when

\footnotetext{
${ }^{39}$ Mary Nooter Roberts, “Altar as Museum, Museum as Altar: Ethnography, Devotion, and Display" in Religion in Museums: Global and Multidisciplinary Perspectives, Gretchen Buggeln, Crispin Paine, S. Brent Plate, eds. (New York and London: Bloomsbury Publishing, 2017), 50.

${ }^{40}$ Phone interview with Tony Dilulio, April 23, 2020.
} 
caring for sacred objects, as curator comes from the Latin "curare" which means "to take care of." 41

Additionally, the act of pilgrimage has encouraged the creation of archives. Those managing pilgrimage sites have collected written documents regarding the shrine's origin, management, authentication, and pilgrims' testimonies. These manuscripts form a small archive that is preserved and maintained for future generations. Pilgrims actively participate in the creation of these archives, allowing them to insert their voice into the historical narrative.

The secularization that came out of the Enlightenment and is inherent within the public history field in the United States strips sacred objects and places of particular histories and meaning. Learning about other religions requires looking at the world from a different perspective or, as religious studies scholar Timothy Beal puts it, "coming to see how something could make sense, could be true and meaningful, within a certain context, according to certain conditions, according to a certain story." 42 History and culture, both in the past and today, are deeply affected by religious views. Religion and faith — whether institutional, personal, or absent — determines the framework by which one understands and makes meaning of the world. While I assert that pilgrimage is a public history phenomenon both in the past and in the present, my thesis will focus on American Catholic pilgrimage at the turn of the twentieth century. Each individual chapter will demonstrate that through pilgrimage, the faithful are engaged in public history in its various forms.

In chapter one, I outline how American Catholic pilgrimage was packaged and marketed, basing my analysis particularly on newspaper articles from The Sacred Heart Review and

\footnotetext{
${ }^{41}$ Christina Kreps, "Indigenous curation, museums, and: intangible cultural heritage," in Safeguarding Intangible Heritage, Natsuko Akagawa and Laurajane Smith, eds. (London: Routledge, 2018), 196.

42 Timothy Beal, Roadside Religion: In Search of the Sacred, the Strange, and the Substance of Faith (Boston: Beacon Press, 2005), 12.
} 
pamphlets created for the American National Catholic pilgrimages of 1896, 1897, and 1908. These institutionally organized pilgrimages gave rise to questions regarding what constitutes a "true pilgrimage" and encouraged pilgrims to identify as American pilgrims. I demonstrate that questions of authenticity and identity, both important concepts within the public history field, played a significant role in American Catholic pilgrimage at the turn of the century.

In chapter two, I argue that both the institutional church and the lay faithful were using pilgrimage to participate in the preservation and promulgation of history through the preservation of historic structures and objects, archaeological projects, archives, educational lectures, interpretative guides, and pilgrimage literature. My conclusions come primarily from the examination of newspaper articles from The Sacred Heart Review, pilgrimage accounts, and contemporary periodicals. Through pilgrimage, Catholics were involved in the preservation and interpretation of tangible forms of heritage.

In chapter three, I describe how pilgrims interacted with cultural landscapes, as they placed themselves in the historical scene through collective memory and embodied acts. The collective memory associated with these sacred spaces was not confined to the pilgrimage journey, but rather extended to life at home through the collecting of souvenirs and mementoes. Pilgrimage practices are framed as opportunities for pilgrims to actively engage in past-making. The evidence I provide will originate predominately from pilgrimage accounts and pilgrimage visual culture. By engaging with intangible heritage, pilgrims connected themselves to those who walked before them and those who would come after, allowing them to identify as part of the universal Catholic Church.

To conclude, I argue that the general public desires to experience the past through heritage tourism and this includes visiting religious sites. Notre-Dame Cathedral in Paris was 
noted as the most popular attraction in Europe, the Sagrada Familia in Barcelona was reported as Spain's most visited monument, and five out of the ten most visited historic sites in the United Kingdom were cathedrals. ${ }^{43}$ If the public is visiting these sites, public historians need to use these spaces as opportunities of encounter and historical education. A collaboration between public historians and religious groups is mutually beneficial. Public historians should help develop the interpretation and preservation of these religious sites, adding historical context to these sacred spaces. In turn, these sites will become more accessible and visible, exposing the public to rich histories that have long been ignored. The discipline does the public a disservice by artificially cordoning off religion from historical interpretation and ignoring sites that are significant due to sacredness.

${ }^{43}$ Michael Stausberg, Religion and Tourism: Crossroads, Destinations, and Encounters (New York: Routledge, 2011), 79. 


\section{CHAPTER ONE}

The Stars and Stripes on Holy Ground:

American Catholic Pilgrimage at the Turn of the Twentieth Century

At the time that the American pilgrims of last summer visited the Vatican, the Pope, after declaring his delight at seeing the beautiful American flag they carried, expressed regret that the pilgrims did not bring a banner for the Vatican, whereupon some of those present promised to send him one as soon as they received home. In accordance with this promise the Brooklyn Catholic Young Women's Association....will have two elaborate silk flags made, of regulation size and texture, and will forward them to Rome, where they will be offered as a Christmas gift to the Pope.

- The Sacred Heart Review, November 2, 1895

A gust of wind whistled past a group of ladies in woolen dresses of dark shades, as they huddled aboard the Amérique. It was an unusually warm day in mid-November of 1875, and the stars and stripes waved merrily overhead. As three guns announced the beginning of an ocean voyage, hundreds of hats, caps, and handkerchiefs bobbed along the pier, wishing those onboard a happy voyage. As the steamer set off from New York in the direction of La Havre, cheerful passengers scattered over the main deck, basking in the bright sunlight. Later in the day, as the sun began its descent towards the horizon, an older gentleman sporting a long white beard and rounded spectacles meandered his way around the deck, enlisting passengers to gather in a large crowd. The older gentleman was recognizable even to those who did not know him personally, in his black cassock tied at the waist and topped with a black cape. The gentleman introduced himself as Father Edward Sorin, the superior general of the Congregation of Holy Cross, and launched into a string of prayers, followed by a reverent hymn. As "Ave Ave Ave Marias" echoed across the ocean waves, a young woman whispered a question to her companion. "When will we arrive to see our Holy Father?" Her companion, a middle-aged woman, laughed at her impatience but was also restless to reach their final destination: Rome. The Eternal City. The 
ultimate goal of their pious pilgrimage. ${ }^{1}$

As American Catholics began participating in pilgrimage journeys at the end of the nineteenth century, both clergy members and tourist agencies recognized the need for nationally organized pilgrimages. Bishops and priests acted as spiritual directors on these voyages, while lay people established itineraries and enlisted travel agents to ensure the trip ran smoothly. Pilgrimage organizers published advertisements in newspapers and created pamphlets to encourage pilgrims to sign up for their transatlantic tours. The advertised comfort and convenience that these pilgrimages provided to pilgrims caused American Catholics to question whether the journeys could be considered "true pilgrimage." Authenticity is a central concern when maintaining historic buildings, sites, objects, or heritage, and the same was true of pilgrimage at the turn of the twentieth century. The desire to determine the elements of authentic Catholic pilgrimage was a push against the increasingly popular Protestant pilgrimage movement. American Catholics connected their pilgrimage practices to a long history of Catholic pilgrimage, allowing them to distinguish "true" Catholic pilgrimage from Protestant pilgrimage. Through this distinction, American Catholics were constructing a Catholic identity for themselves within the United States, however, American Catholics were also careful to identify as American pilgrims when interacting with sacred spaces abroad. American national Catholic pilgrimage was a venue by which pilgrims were able to identify as both Catholic, within Protestant America, and American, within the universal Church.

The burgeoning tourist industry of the nineteenth century facilitated travel and pilgrimage

\footnotetext{
${ }^{1}$ Description taken and adapted from the chapter "Adrift," "The First View of Rome," and "Pio Nono" in Pilgrims and Shrines by Eliza Allen Starr (Chicago: Eliza Allen Starr, 1885). The middle-aged companion is the author, Eliza Allen Starr, who was 51 during the pilgrimage. The author mentions that Father Edward Sorin accompanied the group on their pilgrimage. The description of Father Edward Sorin comes from "Father Edward Sorin CSC" on Wikimedia Commons, https://commons.wikimedia.org/wiki/File:Rev_Edward_Sorin.jpg. The description of the women's dresses comes from The Art of Dressing Well (1870).
} 
to Europe and the Holy Land. Tourist companies such as Thomas Cook \& Son and American Express, founded in the 1860s, organized both tours and pilgrimages to the Holy Land and abroad. $^{2}$ New shipping lines to Palestine facilitated travel from the West and made it more affordable. Once on holy soil, pilgrims made their way to Jerusalem and the Church of the Holy Sepulchre, and then visited the surrounding countryside, dotted with other holy sites. Often pilgrims planned their travel to coincide with religious festivals or holy seasons, with Easter and Christmas constituting the peak seasons. Pilgrimages tended to last several weeks or even months. ${ }^{3}$ Pilgrims performed various religious rituals when on pilgrimages including lighting candles, having objects blessed, participating in mass, and obtaining indulgences. Many of these rituals were performed in public and in groups, and pilgrims wore uniform clothes or pilgrim badges to identify themselves as religious travelers. ${ }^{4}$ Pilgrim groups lodged in churches, monasteries, nunneries, hostelries, and tents. By the end of the nineteenth century, hotel construction flourished in Palestine, but these lodgings were considerably more expensive. ${ }^{5}$ Priests, either local or from home, served as the pilgrims' guide and religious authority. Pilgrims collected as many souvenirs as possible on their trip, as pilgrims believed these mementos were sacred and had the power to sanctify their own homes in the United States. ${ }^{6}$

Pilgrimage accounts of European Catholics were popular in the United States, even before American Catholics performed pilgrimages of their own. Before the Civil War, there were not many American Catholics traveling to the Holy Land, most likely due to their immigrant poverty. ${ }^{7}$ The earliest reference of American Catholic pilgrimage is a pilgrimage to Rome taken

\footnotetext{
${ }^{2}$ Bar and Cohen-Hattab, "A New Kind of Pilgrimage," 133.

${ }^{3}$ Ibid., 137.

${ }^{4}$ Ibid., 139.

${ }^{5}$ Ibid., 140.

${ }^{6}$ Ibid., 142.

${ }^{7}$ Hennesey, American Catholics, 175.
} 
by Timothy Bermingham, from the Diocese of Charleston, in $1861 .{ }^{8}$ Before returning home, Bermingham took a short tour of the Holy Land. In 1867, James Roosevelt Bayley, the first bishop of Newark, went on pilgrimage to Rome and the Holy Land. In the nineteenth century, there was not a great deal of travel literature published for an American Catholic audience. In 1869, a Belgian Franciscan friar with ten years of travel experience to Palestine published a guidebook to the Holy Land in French, but an American edition was not published until 1898. This is likely indication that there were enough American Catholics traveling to the Holy Land only at the end of the nineteenth century to warrant its publishing in the United States.

According to historian David Klatzker, a new Catholic religiosity took hold at the end of the nineteenth century. ${ }^{9}$ The Church established several pilgrimage sites in the United States, including eleven shrines founded prior to 1880 . Five of them contained relics or replicas of sacred images, and six of them memorialized an alleged supernatural event. ${ }^{10}$ Pope Pius IX (1846-1878) granted indulgences for pilgrimages to Our Lady of the Angels near Niagara Falls, New York and Notre Dame, Indiana, as they were both replicas of a shrine in France. The Holy House of Nazareth in Notre Dame, Indiana was also indulgenced, as it was a replica of a shrine in Italy. ${ }^{11}$

An analysis of The Sacred Heart Review helps flesh out American Catholic pilgrimage. The newspaper mentioned pilgrimage sites around the world including popular shrines such as Lourdes, France; St Anne de Beaupré, Canada; and Guadalupe, Mexico. However, the paper also described shrines in Italy, Switzerland, Wales, Poland, Luxemburg, Austria, Malta, Martinique, Cuba, Montenegro, Mexico, and Algeria. Pilgrimage sites in western Pennsylvania, in upstate

\footnotetext{
${ }^{8}$ Klatzker, "American Catholic Travelers to the Holy Land," 57.

${ }^{9}$ Ibid., 60.

${ }^{10}$ Taves, The household of faith, 99.

${ }^{11}$ Ibid.
} 
New York, and on Staten Island were mentioned as well.

American Catholics were making pilgrimages to sacred sites within the country. An article at the end of April in 1896 announced that the year's devotion was to perform "pilgrimages to the shrines of Our Lady." 12 It reminded readers that there were shrines dedicated to the Blessed Mother within the borders of the country, including Mary's First Shrine in the Wilderness in western Pennsylvania and Our Lady of Martyrs in Auriesville, New York. In June of 1901, close to 1,100 members of the St Vincent de Paul Society of Brooklyn went on pilgrimage to the mission of the Immaculate Virgin at Mount Loretto on Staten Island. ${ }^{13}$ The visit was described as an "annual pilgrimage," so presumably the mission was a regular site of pilgrimage for the faithful in the area. On July 14, 1910, the Catholic Alumni Sodality of Boston organized a pilgrimage to the shrine of Father Jogues in Auriesville, New York, on the feast day of the Assumption of Mary. ${ }^{14}$

The shrine of St Anne de Beaupré in Canada was another popular site of pilgrimage. In 1893, a pilgrimage left Boston for the shrine, coinciding with the feast day of the Assumption of Mary. ${ }^{15}$ In the summer of 1898, a large pilgrimage left Springfield, Massachusetts, for the shrine, under the spiritual direction of a French-Canadian priest. A number of the participants were yearly pilgrims to the miraculous shrine. ${ }^{16}$ An article on July 15, 1899 reported that the "annual pilgrimage" from Springfield to St Anne de Beaupré left on the $11^{\text {th }}$ with a large number of Catholics from various regions of western Massachusetts. ${ }^{17}$ In July of 1900, a thousand pilgrims left Worcester, Massachusetts, for their "annual pilgrimage" to the Canadian shrine, and another

\footnotetext{
12 "The May Intention," Sacred Heart, April 25, 1896. "Our Lady" refers to Mary, the mother of Jesus.

${ }^{13}$ Sacred Heart, June 29, 1901.

${ }^{14}$ Sacred Heart, July 9, 1910.

${ }^{15}$ Sacred Heart, July 22, 1893.

${ }^{16}$ Sacred Heart, June 25, 1898; Sacred Heart, July 2, 1898.

${ }^{17}$ Sacred Heart, July 15, 1899.
} 
pilgrimage left from Boston. ${ }^{18}$ The "people of the New England states" had the opportunity to go on pilgrimage to St Anne de Beaupré on July 23, 1905. The trip included tours of Quebec City and Montreal. ${ }^{19}$ The shrine continued to attract American pilgrims throughout the early twentieth century, evident by the advertisement for St Anne de Beaupré in America in $1921 .^{20}$

Pilgrimages to destinations across the Atlantic Ocean were more prevalent in pilgrimage literature of the period. Father Nelson Henry Baker led the first American Catholic tour of European holy places in 1874. Pope Leo XIII (1878-1903) took an interest in the Holy Land and granted a Cross of Honor to anyone who made a pilgrimage there. The Holy See established the Franciscan Commissariat of the Holy Land for the United States in 1880 under the direction of Father Charles A. Vassani. ${ }^{21}$ The mission of the commissariat was to raise funds for shrines, parishes, schools, orphanages, and hostels in the Holy Land, maintained by the Franciscans.

Father Vissani led the first organized American Catholic pilgrimage to the Holy Land in 1889. ${ }^{22}$ The group consisted of ninety-nine pilgrims, thirty-nine of them clergymen and twentyeight of them women. ${ }^{23}$ Thomas Cook \& Son functioned as their travel agent, which allowed the pilgrims to receive letters of credit from the company, payable in all countries on the itinerary, in the appropriate currency. ${ }^{24}$ The pilgrim group first visited France (Paris, Marseilles, and Nice), then Italy (Genoa, Pisa, Florence, Assisi, Rome, and Naples), then Egypt (Alexandria, Cairo, the Pryamids, Ismailia, and the Suez Canal) before reaching the Holy Land. In Rome, the pilgrims had an audience with Pope Leo XIII, and they each received a silver medal from the Holy Father

\footnotetext{
18 Sacred Heart, July 21, 1900; “A Pilgrimage from Boston to St Anne de Beaupre, Ca.," Sacred Heart, June 23, 1900.

19 Sacred Heart, June 10, 1905.

${ }^{20}$ America, June 25, 1921.

${ }^{21}$ Ibid.

22 Klatzker, "American Catholic Travelers to the Holy Land," 64.

${ }^{23}$ James Pfeiffer, First American Catholic Pilgrimage to Palestine, 1889 (Cincinnati: J. Berning, 1892$), 8$.

${ }^{24}$ Ibid., 3.
} 
as a memento. ${ }^{25}$ When participating in processions at holy sites, Father Vissani carried a banner with a figure of Jesus on one side, and on the other side, the American flag with the inscription "First American Pilgrimage to the Holy Land 1889." ${ }^{26}$ Sensing that the number of American Catholic pilgrims would increase in the coming years, the Commissariat on Pilgrimages to the Holy Land for the United States bought a ship, Our Lady of Safety, to carry pilgrims to Palestine in the fall of $1893 .{ }^{27}$ Although the number of American Catholic pilgrims to the Holy Land increased throughout the nineteenth and twentieth centuries, it never was comparable to the number of Protestant pilgrims. ${ }^{28}$ Rome, the heart of the Catholic Church, was a more popular pilgrimage site for American Catholics.

The first organized pilgrimage to Lourdes from the United States sailed from Brooklyn, New York, on July 18, $1894 .{ }^{29}$ The pilgrims first went to Rome to receive an audience with the Pope, and after Lourdes, spent two weeks visiting Paris and "other interesting places." The pilgrimage cost less than $\$ 300$ per person and attracted four hundred pilgrims. ${ }^{30}$ After they returned home, many of the pilgrims attended a ceremony to erect a statue of Our Lady of Lourdes within St Francis de Sales' Church in Brooklyn. ${ }^{31}$

Following the nationally organized pilgrimage in 1894, various religious orders began regularly planning their own pilgrimages. The Provincial of the Order of Mercy organized a pilgrimage to Lourdes, Paray-le-Monial, and other famous European shrines in the summer of

\footnotetext{
${ }^{25}$ Pfeiffer, First American Catholic Pilgrimage to Palestine, 35-6.

${ }^{26}$ Ibid., 2.

${ }^{27}$ Sacred Heart, November 25, 1893.

${ }^{28}$ Klatzker, "American Catholic Travelers to the Holy Land," 73.

${ }^{29}$ Sacred Heart, April 14, 1894.

30 Sacred Heart, April 14, 1894; Sacred Heart, June 30, 1894; Sacred Heart, August 11, 1894; Sacred Heart, August 18, 1894.

${ }^{31}$ Sacred Heart, October 6, 1894.
} 
1895. ${ }^{32}$ The Fathers of Mercy, a congregation of priests, organized the third American pilgrimage to Rome from Boston in June and July of $1896 .{ }^{33}$ Another American pilgrimage to Rome left aboard the Werra on January 16, 1897, but this pious journey included a pilgrimage to the Holy Land. ${ }^{34}$ Reverend William J. Hill, pastor of St Paul's Church in Brooklyn, led the pilgrims spiritually, but lay-man Francis H. Throop was put in charge. The pilgrimage began in the Holy Land and then proceeded to Rome, for a total duration of three months. ${ }^{35}$

An American pilgrimage to Rome and Lourdes left on July 7, 1897 on the Westernland and another took place in the winter of 1897 to $1898 .{ }^{36}$ A specially chartered steamer, the Aller, sailed the pilgrims to Europe, where they were lodged in first-class hotels. The pilgrimage lasted more than two months with excursions made at Gibraltar, Malaga, and Alhambra, Spain; Algiers, Algeria; Malta; Alexandria and Cairo, Egypt; Jerusalem and "places of sacred interest"; the Syrian coast; Smyrna and Constantinople, Turkey; Athens, Greece; and Naples, Genoa, and Rome, Italy. ${ }^{37}$ There was the possibility to spend Easter and Holy Week in Jerusalem, and in Rome, the pilgrims had the expected audience with the Pope.

An American pilgrimage to Rome took place in the summer of $1900 .{ }^{38}$ In July of 1902 , an American pilgrimage to Rome and "the principal shrines of the continent" left the port of New

\footnotetext{
${ }^{32}$ Francis H. Throop participated in the American pilgrimage to Rome in 1894 as a Protestant but converted to Catholicism when in Lourdes (Sacred Heart, September 7, 1895). The pilgrimage left New York on July $10^{\text {th }}$ and arrived in Rome on August 4 $4^{\text {th }}, 1895$ (Sacred Heart, June 1, 1895; Sacred Heart, June 8, 1895).

${ }^{33}$ One hundred and fifty of the pilgrims were priests from the diocese of New York and Philadelphia. One section of the pilgrims left on the steamer Britannic on June $24^{\text {th }}$ and the second on the Westernland on July $8^{\text {th }}$. The groups met in Antwerp, Belgium on July $19^{\text {th }}$, and visited Rome, Padua, and Loretto in Italy, and Lourdes in France (Sacred Heart, May 30, 1986).

${ }^{34}$ Sacred Heart, January 2, 1897.

${ }^{35}$ Sacred Heart, January 23, 1897. The American pilgrims attended a Pope's Mass in Rome and at their audience, Throop presented the Pope with a white skull cap filled with gold. The pilgrims sailed home on March 27, 1897 (Sacred Heart, April 3, 1897).

${ }^{36}$ Sacred Heart, October 23, 1897. The Bishop of Wichita acted as spiritual director, and the Pope received and blessed the pilgrims on August $7^{\text {th }}$ (Sacred Heart, October 23, 1897).

${ }^{37}$ Sacred Heart, October 23, 1897.

${ }^{38}$ Sacred Heart, September 1, 1900.
} 
York. ${ }^{39}$ The pilgrimage was organized by John J. McGrane, a New York diamond merchant, on the occasion of the pontifical jubilee (a holy year of reconciliation for the Church). This marks a shift in the organization of national pilgrimages in the United States. Once primarily sponsored by religious orders and organized by lay people, the organization transferred to newly established Catholic travel agencies.

The next year on July $4^{\text {th }}$, McGrane organized another pilgrimage to Europe under the name "McGrane's Catholic Tours." 40 The pilgrimage lasted sixty days, included an audience with the Pope, and had an itinerary stretching from Cologne, Germany to Cork, Ireland. ${ }^{41}$ The Pope presented his zucchetto, or skull cap, to McGrane and honored him with the cross "Pro ecclesia et Pontifice," or "Decoration of Honor," reserved for the faithful who have provided distinguished service to the Church. ${ }^{42}$ Advertisements in The Sacred Heart Review for pilgrimages to Rome and Europe organized by McGrane's Catholic Tours appeared in February or March of 1904, 1905, 1906, and 1907. ${ }^{43}$ McGrane's Catholic Tours advertisements were published in The Monitor, a Catholic newspaper in San Francisco, regularly from 1905 to $1910 .^{44}$ The Denver Catholic Register published McGrane's Catholic Tours advertisements in 1912 and 1914. ${ }^{45}$ America, a weekly Catholic magazine founded in 1909, published advertisements for

\footnotetext{
${ }^{39}$ Sacred Heart, June 7, 1902. McGrane's stated profession is found in The Catholic Telegraph, October 29, 1903.

${ }^{40}$ Sacred Heart, April 4, 1903.

41 "Catholic Pilgrimage," Sacred Heart, March 14, 1903. The itinerary included Gibraltar, Naples, Pompeii, Capri, Rome, Florence, Venice, Padua, Milan, Lucerne, Interlaken, Geneva, Paris, Lourdes, Strassburg, Cologne, Amsterdam, Antwerp, Brussels, London, Dublin, Belfast, Kilarney, Glengarif, Bantry, and Cork.

${ }^{42}$ Sacred Heart, February 20, 1904.

${ }^{43}$ Sacred Heart, February 20, 1904; Sacred Heart, February 18, 1905; Sacred Heart, February 3, 1906; Sacred Heart, March 2, 1907.

${ }^{44}$ Some examples include "The Pilgrimage To Rome and Tour of Europe Vs. Mountain and Sea Shore Resorts," The Monitor, May 27, 1905; Advertisements, The Monitor, March 24, 1906; "Holy Land. Rome. Lourdes and Loreto," The Monitor, November 16, 1907; "The Golden Jubilee Pilgrimage to Rome," The Monitor, February 15, 1908; "Has Summer's Pilgrimage to Rome and Town of Europe," The Monitor, February 20, 1909; Advertisements, The Monitor, March 19, 1910.

45 "Pilgrimages to Rome and Lourdes," Denver Catholic Register, March 7, 1912; "Pilgrimages to Rome and Tours of Europe," Denver Catholic Register, February 19, 1914.
} 
pilgrimages to Rome, Lourdes, and Europe run by McGrane's Catholic Tours in 1921 and 1922. ${ }^{46}$ McGrane's Catholic Tours appears to have established itself as the premier Catholic travel agency in the early twentieth century.

Both the early American national Catholic pilgrimages and the later pilgrimages organized by McGrane's Catholic Tours were efficiently planned tours of historic locales. ${ }^{47}$ Pilgrimage organizers worked with train companies to set up special trains reserved for pilgrims. ${ }^{48}$ The use of special trains for pilgrimage was widespread across the United States, Canada, and Europe, and these railways made once out-of-the-way sacred sites accessible and fostered a sense of community among pilgrim groups. ${ }^{49}$ This parallels the way transportation facilitated the tourist industry in the US with locales such as Yellowstone and the Grand Canyon. Scholars such as Marguerite Shaffer have argued that the development of the tourism industry in the United States allowed Americans to create a national identity for themselves. ${ }^{50}$ In the same way, the nationally organized American Catholic pilgrimage became a venue by which American Catholics could forge their own identity.

American Catholics prepared for pilgrimage much in the same way as one would prepare

\footnotetext{
${ }^{46}$ America, June 25, 1921; America, April 22, 1922.

${ }^{47}$ The pilgrimage organizers of the late nineteenth century contracted travel agencies such as Thomas Cook \& Sons and Henry Gaze \& Sons to organize their lodgings, meals, lines of credit, and transportation (Antón M. Pazos, "A new golden age of pilgrimages" in Nineteenth-Century European Pilgrimages: A New Golden Age (New York and London: Routledge, 2020), 5); By the time John McGrane established his own venture, these sorts of tasks were managed in house.

${ }^{48}$ Gábor Barna, "National Pilgrimages, Pilgrim Trains and Identity-Building," Religion, Culture, Society: Yearbook of the MTA-SZTE Research Group for the Study of Religious Culture 2 (2015), 189.

49 Just a few examples of references to special trains for pilgrimage can be found in A Pilgrimage to the Shrine of Our Lady of Martyrs: Auriesville, NY, 1890, 1295 NY032, Printed Ephemera, The Catholic University of America, The American Catholic History Research Center and University Archives, Washington, DC; Marion Bowman, "Railways, Rivalry and the Revival of Pilgrimage in Glastonbury, 1895 and 1897," Religion, Culture, Society: Yearbook of the MTA-SZTE Research Group for the Study of Religious Culture 2 (2015): 173; "Pilgrims in Ste Anne's Shrine," The Catholic Telegraph, April 11, 1901; Richard F. Clarke, Lourdes, Its Inhabitants, Its Pilgrims and Its Miracles. With an Account of the Apparitions at the Grotto and a Sketch of Bernadette's Subsequent History (New York: Benziger, 1905); John M. Raphael, "My Pilgrimage to Lourdes," The London Magazine, November 1901; "The Coming Pilgrimage to Rome," The Monitor, March 14, 1908.

${ }^{50}$ Marguerite S. Shaffer, See America First: Tourism and National Identity, 1880-1940 (Washington: Smithsonian Institution Press, 2001).
} 
for any kind of excursion abroad. Reverend E. W. J. Lindesmith, a pilgrim on the winter pilgrimage of 1897 , left papers held at the archives of the Catholic University of America that shed some light on how pilgrimage organizers prepared prospective pilgrims for their journey. Pilgrimage organizers were in regular contact with prospective pilgrims regarding their choice of itinerary, payment, and answering any questions they may have. ${ }^{51}$ Reverend Lindesmith prepared for the pilgrimage by sifting through possible supplies for his journey. Lindesmith collected a pamphlet on the Kenwood Rug, a large blanket for traveling, as well as a pamphlet from The Popular Trunk Shop, a shop dedicated to helping individuals prepare for their "European tour." 52 He considered purchasing travel insurance, evident by four insurance pamphlets within his possession. ${ }^{53}$ Lindesmith inquired about how to obtain letters of credit for the pilgrimage, what clothing was necessary for the trip, how to obtain a steamer chair, and how to apply for a passport required to enter Palestine. ${ }^{54}$ All of these considerations would have been standard for a European tour and not particular to preparing for a religious journey.

Pilgrimage pamphlets encouraged pilgrims to do some preliminary study before the

\footnotetext{
${ }^{51}$ Correspondence from Mr Francis H. Throop to Rev E. W. J. Lindesmith, November 27, 1896, ACUA 024, Box 7 , Folder 2, Rev Eli Washington John Lindesmith papers, The Catholic University of America, The American Catholic History Research Center and University Archives, Washington DC; Correspondence from Mr Francis H. Throop to Rev E. W. J. Lindesmith, December 14, 1896, ACUA 024, Box 7, Folder 2, Rev Eli Washington John Lindesmith papers, The Catholic University of America, The American Catholic History Research Center and University Archives, Washington DC; Correspondence from Mr Francis H. Throop to Rev E. W. J. Lindesmith, January 2, 1897, ACUA 024, Box 7, Folder 2, Rev Eli Washington John Lindesmith papers, The Catholic University of America, The American Catholic History Research Center and University Archives, Washington DC; Correspondence from Mr Francis H. Throop to Rev E. W. J. Lindesmith, January 6, 1897, ACUA 024, Box 7, Folder 2, Rev Eli Washington John Lindesmith papers, The Catholic University of America, The American Catholic History Research Center and University Archives, Washington DC.

52 Kenwood Rug Pamphlet, ACUA 024, Box 7, Folder 2, Rev Eli Washington John Lindesmith papers, The Catholic University of America, The American Catholic History Research Center and University Archives, Washington DC; Correspondence from The Popular Trunk Shop: European Outfitters in New York to Rev E. W. J. Lindsmith, Ohio, December 17, 1896, ACUA 024, Box 7, Folder 2, Rev Eli Washington John Lindesmith papers, The Catholic University of America, The American Catholic History Research Center and University Archives, Washington DC. ${ }^{53}$ Correspondence, Pilgrimage to the Holy Land, 1896, ACUA 024, Box 7, Folder 2, Rev Eli Washington John Lindesmith papers, The Catholic University of America, The American Catholic History Research Center and University Archives, Washington DC.

${ }^{54}$ Francis H. Throop to Rev E. W. J. Lindesmith, December 14, 1896.
} 
voyage, stating "a little preparatory study of the well-known books treating of these places and their attractions will greatly enhance the pleasure of the visit to each." ${ }^{.55}$ Reverend Lindesmith wished to take this advice, as he sent a letter to the pilgrimage organizers inquiring where he could purchase "the most complete guidebook" of Switzerland. ${ }^{56}$ Francis H Throop, the pilgrimage organizer, replied that the Baedeker guide (a staple for tourists in Europe during the period) was the best but was published in ten volumes. A guide to Europe and the Holy Land by Father Fairtank, Throop suggested, gave "the best general idea on any guide book I have seen." 57 Additionally, Lindesmith possessed an advertisement for Reverend James Pfeiffer's published account of the First American Catholic Pilgrimage to Palestine in 1889. Most likely, he desired to prepare for the pilgrimage by reading accounts on the history of the locales he would soon visit.

Pilgrimage organizers encouraged prospective pilgrims to view the pilgrimage as both a spiritual journey, but also as a chance to explore the European continent. Nationally organized pilgrimages often had several sections leaving or returning to the United States on different days and with additional tours in various countries. The winter pilgrimage of 1897 offered a supplementary extension which included tours of Venice, Milan, the Swiss Lakes, Bale, Paris, Dieppe, and London. ${ }^{58}$ Pilgrims had the opportunity to extend their tour of Europe and were also free to break off from the pilgrimage group at their leisure at any point during the journey. "YOU CAN STAY LONGER" appeared in all-caps in the pamphlet advertising the pilgrimage. ${ }^{59}$ Both

\footnotetext{
${ }^{55}$ Third Annual American National Pilgrimage, 1896, PO18.363, Printed Ephemera, Catholic Historical Research Center of the Archdiocese of Philadelphia, Philadelphia, PA.

${ }^{56}$ Correspondence, Pilgrimage to the Holy Land, 1896.

${ }^{57}$ Francis H. Throop to Rev E. W. J. Lindesmith, December 14, 1896.

${ }^{58}$ American National Pilgrimage pamphlet, 1896, ACUA 024, Box 7, Folder 2, Rev Eli Washington John Lindesmith papers, The Catholic University of America, The American Catholic History Research Center and University Archives, Washington DC.

${ }^{59}$ Ibid.
} 
the train tickets and the ocean passage included in the pilgrimage's price were valid up to a year after they were issued. ${ }^{60}$ Pilgrimage organizers made this known both in letters to pilgrims and in promotional pamphlets. $^{61}$

In a promotional pamphlet for the pilgrimage in Reverend Lindesmith's possession, an itinerary of the journey is included with certain locales bolded to draw attention. Some of the bolded locations are what you would expect in a pamphlet advertising a religious journey. The Church of the Annunciation in Genoa, the Franciscan Convent in Jaffa, and Jerusalem are all sites that readers would associate with their faith. Other destinations have no religious affiliation. Pompeii, Vesuvius, the Pyramid of Sakhara, and Colossus are a few of the bolded sites that appeal to the tourist rather than the pilgrim. ${ }^{62}$

However, the authors of the pamphlet wanted to make it clear that the "pilgrimage has been arranged primarily to visit Rome and the Shrines and Holy Places of Palestine as an act of piety and devotion" and that they would never lose "sight of the main object of our journey—the Land of Promise of the Jews, the land wherein the "word was made flesh." ${ }^{63}$ Nonetheless, the organizers promised that "care has been taken not to lose any of the educational advantages to be gathered by the way" as "nothing is so broad an educator as travel and observation." 64 The same language was used in the promotional pamphlet for the national pilgrimage of 1896, organized by Francis H. Throop. ${ }^{65}$

Advertisements published in newspapers and pamphlets included letters of endorsement from American clergy members. An endorsement gave a pilgrimage legitimacy and conveyed

\footnotetext{
${ }^{60}$ Francis H. Throop to Rev E. W. J. Lindesmith, Nov 27, 1896;

${ }^{61}$ Ibid.; Francis H. Throop to Rev E. W. J. Lindesmith, December 14, 1896; American National Pilgrimage pamphlet, 1896.

${ }^{62}$ American National Pilgrimage pamphlet, 1896.

${ }^{63}$ Ibid.

${ }^{64}$ Ibid.

${ }^{65}$ Third Annual American National Pilgrimage, 1896.
} 
the hierarchy's confidence in the pilgrimage's organizers. ${ }^{66}$ Francis Cardinal Satolli, the Apostolic Delegation of the United States, gave an endorsement on behalf of the Pope, stating "I take pleasure in informing you that the Holy Father, having heard that again this year a Pilgrimage to Rome and the Sanctuaries of the Blessed Virgin is to be organized in this country, has been pleased to impart to the undertaking his Apostolic Blessing." ${ }^{67}$ Later pamphlets promoting pilgrimages organized by John McGrane included a similar endorsement. "To dearly beloved son, Cav J. J. McGrane, and to all equally dear American pilgrims, wishing from God His choicest graces, we heartily impart the Apostolic Blessing. From the Vatican." ${ }^{\prime 68}$ Several other newspaper advertisements for McGrane's Catholic Tours publicized the fact that a bishop would act as spiritual director. ${ }^{69}$ An advertisement in The Monitor from 1906 reminded visitors that "the fact that the Rt Rev Bishop Gabriels will be the Spiritual Director is in itself sufficient assurance that the members will see in a satisfactory manner all the principal places of religious and historic interest throughout Europe."70 When considering a religious journey, pilgrims looked for assurance from the institutional hierarchy that a pilgrimage was worthwhile.

As pilgrimage organizers recognized that prospective pilgrims had both religious motivations and an eagerness to learn about art, architecture, and historical structures, they catered their advertisements to these desires. A pamphlet for the pilgrimage of 1896 proclaimed that "the pilgrims will see all that is best of European art and civilization" and "cathedrals and

\footnotetext{
${ }^{66}$ Third Annual American National Pilgrimage, 1896.

67 Ibid.

${ }^{68}$ Holy Father's Golden Jubilee, Pilgrimage to Rome and Grand Tour of Europe, 1908, P002.0496, Printed Ephemera, Catholic Historical Research Center of the Archdiocese of Philadelphia, Philadelphia, PA.

69 “American Pilgrims See Pope Pius X," The Monitor, December 7, 1907; “Has Summer's Pilgrimage to Rome and Town of Europe," The Monitor, February 20, 1909; "The Pilgrimage to Rome and Ton of Europe," The Monitor, April 7, 1906; Advertisements, The Monitor, March 19, 1910; Advertisements, The Monitor, March 24, 1906; "McGrane's Catholic Tours," Catholic Telegraph, April 9, 1914; “The Pilgrimage To Rome and Tour of Europe Vs. Mountain and Sea Shore Resorts," The Monitor, May 27, 1905; Advertisements, The Monitor, January 8, 1910.

70 "Pilgrimage to Rome," The Monitor, February 10, 1906.
} 
other grand and enduring monuments of Christian art that have stood for centuries." ${ }^{, 11}$ When describing Rome, the pamphlet explained, "here every stone almost is a monument of national interest, a witness of mighty facts from which history weaves its most interesting plot." Art, architecture, and archaeological ruins were attractions mentioned to entice prospective pilgrims. ${ }^{72}$ A pamphlet from a pilgrimage organized by McGrane's Catholic Tours in 1908 listed six advantages of partaking in the pilgrimage. The first mentioned is "religious" and the second listed is "educational." A description for the "educational" advantage reads, "Europe teems with priceless treasures of art and architecture; it is the home of music and the land of history romance; the knowledge acquired is of inestimable value, and, as an educational factor, such a trip cannot be overestimated." ${ }^{\prime 73}$ Pilgrimage organizers used the history and culture of the locales on the tour to attract pilgrims.

Another tactic organizers used to entice pilgrims was an emphasis on the comfort and convenience of the pilgrimage. The pamphlet of the 1896 summer pilgrimage noted that the fare included "first-class steamer and second-class railroad tickets for the tour....hotel accommodations at good, comfortable hotels....transfer of passengers and baggage between stations, piers and hotels.... and the services of an experienced conductor, who will supervise the arrangements throughout." The organizers ensured that "the most may be accomplished in the

\footnotetext{
${ }^{71}$ Third Annual American National Pilgrimage, 1896.

${ }^{72}$ Some of these include paintings by Rubens, the Musée Royal (an art museum) in Antwerp, the Cathedral of Cologne ("one of the largest and finest examples of Gothic to be found"), an old covered bridge in Vitznau from the twelveth century, Leonardo da Vinci's "Last Supper," the Uffizi art museum in Florence (Third Annual American National Pilgrimage, 1896); the site of the Serapeum in Alexandria, the Pyramid of Cheops, the Tomb of Numbers, the ruins of ancient Pompeiopolis, the ruins in Ephesus, the Acropolis and the Parthenon in Athens, the Archaeological Museum in Athens (Correspondence, Pilgrimage to the Holy Land, 1896); Pompeii, the fortifications at Gibraltar, the art galleries of the Pitti in Florence ("containing a wonderful collection of pictures and sculptures"), the Cathedral of Milan ("the most beautiful example of Gothic Architecture"), the Museum of paintings in Brussels, the National Gallery in London (Holy Father's Golden Jubilee, Pilgrimage to Rome and Grand Tour of Europe, 1908).

${ }^{73}$ Holy Father's Golden Jubilee, Pilgrimage to Rome and Grand Tour of Europe, 1908.
} 
shortest time without unnecessary fatigue."74 The pamphlet for the winter pilgrimage of 1897 claimed that "no tour simply for pleasure or instruction can offer superior attractions or better advantages and accommodations while neither pleasure nor instruction need to be sacrificed." ${ }^{\prime 75}$ The pamphlet for the summer pilgrimage of 1908 announced that the group would "travel in our own special railroad trains, and be surrounded throughout with every possible comfort." One of the "advantages" listed on the pamphlet was "comfort," which explained,

Night and Sunday travel by rail will be avoided. Members will have absolutely no care. Management will assume everything, including care of baggage, passing same through custom houses; gratuities to hotel servants, railroad porters and guards; furnish guides and couriers; provide comfortable trains and first-class hotels. Will, in a word, save them the thousand and one annoyances incidental to travelers in a foreign country. ${ }^{76}$

Some advertisements published in newspapers utilized the same inclination for comfort when promoting their trips. ${ }^{77}$

An analysis of The Sacred Heart Review and other contemporary newspapers and pilgrimage accounts exposes a tension in the literature between "true pilgrimage" and comfortable touristic travel. Traditionally, the faithful understood pilgrimage as an act of penance, some going as far as performing self-flagellation as they stumbled to sacred sites. The common belief was that the longer and more arduous the pilgrimage, the greater its religious

\footnotetext{
${ }^{74}$ Third Annual American National Pilgrimage, 1896.

${ }^{75}$ American National Pilgrimage pamphlet, 1896. The pamphlet highlighted the "very low cost....without the sacrifice of first-class accommodation." A "competent" conductor was to remain with the pilgrims throughout the trip and circular notes issued by Henry Gaze \& Sons were payable at "every principal point on the route, in the currency of the country where the party happens to be at the time."

${ }^{76}$ Holy Father's Golden Jubilee, Pilgrimage to Rome and Grand Tour of Europe, 1908. It continued on to read "as compared with independent travel, where one gets but little pleasure and pays well for experience, our parties are so arranged as to permit all to enjoy themselves, without any cares or responsibilities."

${ }^{77} \mathrm{An}$ ad for an American national pilgrimage to the Holy Land and Rome in 1897 described the travel and accommodations as "first-class only" (Fig. 1). An ad for a pilgrimage to St Anne de Beaupré from 1905 encouraged those interested, to commit as soon as possible as "the sooner the names are received, the more perfect hotel arrangements can be secured" (Fig. 2). Another advertisement for a pilgrimage to St Anne de Beaupré from 1921 did the same thing, reminding readers that "early booking [is] essential to secure choice of staterooms" (Fig. 3).
} 
significance. ${ }^{78}$ An article from December 1, 1900 asked,

If all these pilgrimages, devotions, acts of homage, jubilee exercised of whatever kind, leave us no better than we were before; if we do not show by our daily lives that we are nearer to God, living more really after the pattern of His Sacred Heart, more faithful to Him, more loving to our fellow men, what will the...year avail us? ? $^{79}$

American Catholics held an understanding of pilgrimage that emphasized a growth toward holiness by directing one's attention to the Divine throughout one's journey.

The Franciscans, who cared for the Catholic institutions in the Holy Land, recognized a serious difference between tourism and pilgrimage. They maintained that tourists were frivolous and superficial and advised pilgrims to avoid tour agents such as Thomas Cook $\&$ Son. ${ }^{80}$ According to an article from July 24, 1897, there were three ways to go on pilgrimage: as a "true pilgrim," as a second-class train passenger, or worse, as a first-class passenger. The author informed readers, "as the first-class is not only double the cost, but practically shuts you out from seeing the people of the country, very few sensible travelers enter the palace cars." ${ }^{" 11}$ The author continued, "when on a true pilgrimage the cars are crowded with the maimed, the lame, the halt, and the blind." $" 82$ Another author made the same argument, as he criticized some modern pilgrims stating, "they will go by special and luxurious trains to visit at their leisure." ${ }^{83}$ An article from September 10, 1898 proclaimed that "the most lukewarm Christian would blush to complain of a trifling discomfort, when he goes on a pilgrimage." ${ }^{\circledR 4}$ It was imperative for some authors to specify that these pilgrimages were "no holiday excursion, [but] a real religious journey." ${ }^{\prime 5}$ The pious atmosphere of sacred sites had the power of making "a pilgrim of a holiday-maker in about

\footnotetext{
${ }^{78}$ Bar and Cohen-Hattab, “A New Kind of Pilgrimage," 139.

79 "The December Intention," Sacred Heart, December 1, 1900.

${ }^{80}$ Klatzker, "American Catholic Travelers to the Holy Land 1861-1929," 64.

81 "The Lourdes of America," Sacred Heart, July 24, 1897.

${ }^{82}$ Ibid.

83 "The Revival of the Pilgrimage," Sacred Heart, October 21, 1893.

84 "Catholic Thought and Events in Foreign Lands," Sacred Heart, September 10, 1898.

85 “A Modern Pilgrim to Rome," Sacred Heart, July 15, 1893.
} 
a day and a half without his knowing it," according to a pilgrim to France. ${ }^{86}$ At the end of the nineteenth century, American Catholics found it important to make the distinction between pilgrim and tourist, from the time one stepped off one's threshold to the point when one returned home.

Climbing onto a train car signified the start of a sacred journey for many. A pilgrim to Lourdes published an account in 1901 in which he wrote, "the pilgrimage has started as soon as the train leaves the station. ${ }^{" 87}$ He described the never ceasing prayer in the third-class train car that was filled to the brim with the sick, nuns, and lay nurses. Father Vetromile, a Catholic priest, chronicled in his own account that as pilgrims crossed the Atlantic on a steamer, they recited prayers and belted hymns. ${ }^{88}$ An article in The Sacred Heart Review reporting a pilgrimage from London to Rome announced that each train car had a spiritual leader, normally a priest. As the railway carriage rattled across the tracks, the pilgrims had devotions three times a day that included prayers, the rosary, and hymns. ${ }^{89}$ A pilgrimage to St Anne de Beaupré consisted of "lots of prayer during the train journey." 90 An account of the first American Catholic pilgrimage to the Holy Land included a description of Mass held on the steamer with a portable altar. ${ }^{91}$

Some articles specified the lodging arrangements pilgrims made for themselves, demonstrating what they considered to be appropriate housing for a pious quest. Pilgrim houses or hospices established by Catholic institutions in Jerusalem were popular for Americans making pilgrimages to the Holy Land. ${ }^{92}$ By 1895 , the Franciscans opened nine houses of hospitality that

\footnotetext{
${ }^{86}$ M. E. Francis, Little Pilgrims to Our Lady of Lourdes (New York: P. J. Kennedy \& Sons, 1916), 189.

${ }^{87}$ Raphael, "My Pilgrimage to Lourdes," 352.

${ }^{88}$ Eugene Vetromile, Travels in Europe, Egypt, Arabia Petraea, Palestine and Syria (D. \& J. Sadlier \& Company, $1871), 26$.

89 “A Modern Pilgrimage to Rome," Sacred Heart, July 15, 1893.

90 "Good St Anne," Sacred Heart, November 16, 1895.

${ }^{91}$ Pfeiffer, First American Catholic Pilgrimage to Palestine, 1889, 11.

92 Bar and Cohen-Hattab, “A New Kind of Pilgrimage," 139.
} 
had lodged 46,392 pilgrims in the previous six years. ${ }^{93}$ An article in The Sacred Heart Review promised that "rich and poor are received on equal footing" with "no charges made for entertainment." 94 Pilgrims to Lough Derg in Ireland lodged in a hospice. ${ }^{95}$ Pilgrims who visited the shrine of St Anne de Beaupré had the opportunity to stay in locals' homes at "very moderate prices." 96 The first American Catholic pilgrimage to the Holy Land included spending three weeks under a tent. ${ }^{97}$ Many articles from The Sacred Heart Review painted the modest accommodations pilgrims acquired as a significant component of a pilgrimage journey, as they were in line with the penitent nature of pilgrimage. An aura of penance is what connected modern pilgrimage to medieval pilgrimage, bestowing authenticity to the experience.

Other American Catholics did not recognize uncomfortable accommodations as a requirement of authentic pilgrimage. By the end of the nineteenth century, a large Catholic middle class emerged in the United States. ${ }^{98}$ Some Catholics at the turn of the century had the means to travel, and it appears that they wanted to travel in comfort. In an article as early as December 6, 1890, a pilgrim complained of the poor conditions of the hotels in Lourdes, stating, "it is to be hoped that much more may be done for the convenience of those who are accustomed to different accommodations." 99 While the pilgrims on the first American Catholic pilgrimage to the Holy Land slept under tents during a portion of their trip, they held first-class tickets across the Atlantic and stayed in first-class hotels in locations such as Paris, Nice, and Constantinople. ${ }^{100}$ The pilgrimage account described these hotels as "the finest," "very roomy,"

\footnotetext{
93 Sacred Heart, October 5, 1895.

94 “Catholics in Jerusalem," Sacred Heart, March 26, 1898.

95 Sacred Heart, June 27, 1891.

96 "The Feast of St Anne," Sacred Heart, July 25, 1891.

${ }^{97}$ Pfeiffer, First American Catholic Pilgrimage to Palestine, 1889, 146.

${ }^{98}$ Dolan, The American Catholic Experience, 142.

99 “Father O'Donnell's Letter," Sacred Heart, December 6, 1890.

${ }^{100}$ Pfeiffer, First American Catholic Pilgrimage to Palestine, 1889, 9.
} 
and "elegant." 101 Father Vetromile and his fellow pilgrims may have been praying and singing hymns every morning as they sailed across the Atlantic, but they all lodged in first-class cabins. ${ }^{102}$ A pilgrimage from Paris to Reims included "princely spaces for hospitality." 103 By January 14, 1893 an article reported that hotels and accommodations in Lourdes were of the first class. ${ }^{104}$ These lavish accommodations would not have encouraged penance and seem to cut against contemporary notions of authentic pilgrimage, but they were enticing to many American Catholics.

Advertisers at the turn of the century used various techniques to attract pilgrims whether through luxurious lodging or affordability. An advertisement from 1903 for a pilgrimage to Europe promised "seeing the best of Europe at a nominal cost." 105 A month later an advertisement for the same pilgrimage encouraged "those who have time and a little money" to consider making the journey. ${ }^{106}$ A short article in reference to a pilgrimage to St Anne de Beaupré described the round trip ticket and hotel accommodations as "very reasonable." ${ }^{107}$ In 1922, an advertisement for a pilgrimage to Europe promoted "rates the lowest possible consistent with good services and bringing back every person satisfied" (Fig. 4). These advertisements were targeting a financially conscious middle class and presented a more modest version of pilgrimage that would have satisfied American Catholics concerned with faux renditions of pilgrimages.

Some Catholic authors argued that the division between pilgrimage and tourism was clear and distinct, but in several articles and accounts the separation blurs. The first American pilgrimage to Lourdes included spending "two weeks visiting Paris and other interesting

\footnotetext{
${ }^{101}$ Pfeiffer, First American Catholic Pilgrimage to Palestine, 1889, 18, 193.

102 Vetromile, Travels in Europe, Egypt, Arabia Petrcea, Palestine and Syria, 26.

103 “General Foreign Notes," Sacred Heart, October 3, 1896.

104 Sacred Heart, January 14, 1893.

105 “Catholic Pilgrimage," Sacred Heart, March 14, 1903.

106 Sacred Heart, April 18, 1903.

107 Sacred Heart, June 10, 1905.
} 
places." 108 A pilgrimage from Paris to Bona, Algeria, offered optional "excursions" to Carthage, Biskra, and other African cities. ${ }^{109}$ A pilgrim wrote of his pilgrimage to a shrine in Auriesville, New York, maintaining that "no pleasanter spot for a vacation could be found." 110 Some pilgrims on a pilgrimage from Vienna to Mariazell, Austria, made some "excursions" into the neighboring country. ${ }^{111}$ A pilgrim to St Anne de Beaupré mentioned additional visits to Quebec City and Montreal while on pilgrimage. ${ }^{112}$ An article published a letter by an Austrian on pilgrimage to Lourdes in which the pilgrim described an "excursion" to Nevers, France. There he walked through a gallery exhibiting the industrial arts, and he visited a china factory. ${ }^{113}$ The use of language such as vacation and excursion, the same vocabulary authors used when decrying fictitious pilgrimage, complicates the definition some Catholics gave the word "pilgrimage."

Even Catholic organizations devoted to leading Americans on pilgrimage did not perceive pilgrimage and tourism as completely distinct, as they advertised both within one journey. An advertisement for a pilgrimage to St Anne de Beaupré emphasizes the sacred journey, as "pilgrimage" is in large bold font at the top of the ad, but in smaller writing on the bottom appears "an opportunity will be given to view the magnificent scenery....and visit the beautiful cities of Quebec and Montreal" (Fig. 5). The 1897 advertisement for the American national pilgrimage to the Holy Land and Rome includes a bolded line reading "including cruise of the Mediterranean” (Fig. 3). McGrane's Catholic Tours advertised in 1905, 1906, and 1907 a "pilgrimage to Rome and Tour of Europe" (Fig.6). The blending of pilgrimage and non-religious sites suggests that American Catholics were redefining what constituted an authentic religious

\footnotetext{
108 Sacred Heart, August 11, 1894.

109 “Catholic Thought and Events in Foreign Lands," Sacred Heart, July 6, 1895.

110 “Auriesville," Sacred Heart, August 31, 1895.

111 "Catholic Thought and Events in Foreign Lands," Sacred Heart, September 7, 1895.

112 “A Congregational Pilgrimage,” Sacred Heart, November 16, 1895.

113 "Catholic Thought and Events in Foreign Lands," Sacred Heart, January 16, 1897.
} 
experience.

Pilgrims themselves influenced the growth of touristic infrastructure at pilgrimage sites such as Lourdes. A resident of Lourdes who wrote a guide for pilgrims to the miraculous grotto outlined the transformation of the village. According to the author, the influx of pilgrims to the small town caused a new, splendid city to emerge, full of stores, villas, convents, and a modern basilica. The town constructed new roads flanked with cafés, restaurants, and grandiose hotels, where one found comfort and elegance. ${ }^{114}$ An English pilgrim described his experience walking through the streets of Lourdes.

On each side of the Boulevard we saw nothing but hotels and repositories, in fact, every house in Lourdes seems to be either a hotel or a shop, where pilgrims can obtain the necessary food and rest as well as the equally indispensable religious souvenirs to be brought for the dear ones at home. ${ }^{115}$

The presence of religious travelers caused a small French town to construct the infrastructure needed to ensure travel for pleasure. Postcards sent home by pilgrims depicting the hotel-lined streets made the transfiguration known even to those who had not stepped foot in Lourdes (see Figs. 7 and 8). The news of newly developed accommodations and amenities would have attracted visitors. Other towns that housed sacred sites experienced the same transformation. The 5,000 inhabitants of Loretto, once a small Italian village, lived "principally by the resort of pilgrims," with at least half a million visiting the Holy House of Loretto annually. ${ }^{116}$ Because of the strong pull that shrines had based on piety, towns transformed into ambiguous sites suitable for the devout pilgrim as well as the tourist desiring ultimate comfort.

American Catholic authors and pilgrimage organizers connected contemporary journeys

\footnotetext{
114 A. Barbet, Guide des Pélerins, (Pau G. Lescher-Montoné, 1911), 24.

115 Francis, Little Pilgrims to Our Lady of Lourdes, 142.

116 Vetromile, Travels in Europe, Egypt, Arabia Petrcea, Palestine and Syria, 294; Charles Warren Stoddard, Two Celebrated Sanctuaries of the Madonna in Italy, 1906, CUA37.42, Printed Ephemera, The Catholic University of America, The American Catholic History Research Center and University Archives, Washington, DC, 41.
} 
to historic pilgrimages of a bygone age. A pamphlet for the winter pilgrimage of 1897 explained that "the prototype of Catholic pilgrimages was probably the annual journey the Jews made to Jerusalem." 117 In a pilgrimage account, a Catholic author wrote of his desire to be a "real pilgrim," referring to the pilgrims of the mediaeval era as the standard. ${ }^{118}$ A Catholic magazine asserted

to a Catholic who understands his faith there is nothing more incongruous in a pilgrimage today to shrines and holy places than there was five centuries ago. The dull brown robe, the staff and scrip and shell, may lend a picturesqueness to the ancient pilgrim which his modern successor lacks. But picturesque appearance is not piety. ${ }^{119}$

However, many authors disagreed with the notion that modern pilgrimage followed in the tradition of mediaeval pilgrimage. Accordingly, the authenticity of these religious journeys was put into question. An article in the Christian Advocate proclaimed that

in olden time the poor pilgrim took a staff and wallet, and, barefooted, made long and wearisome journeys to sacred shrines; but now, forsooth, the "blue bloods" of Europe pack their score of trunks, secure seats in first-class cars, and write ahead to first-class hotels, just like common mortals, for the choice rooms of the palace. ${ }^{120}$ Another article from 1895 stated, "we have not quarrel with the good people who take advantage of cheap fares and a well organized tourist service to see the famous or holy places of the world. But we do protest against labelling the tourist as Pilgrims and against advertising the excursions as pilgrimages." The same article continued to suggest that pilgrims should "see nothing in the cities through which they pass but the shrines of the saints and then not to admire the architecture or the painting but to pray with single heart. Thus they would be like unto the pilgrims of old."121 In 1874, right as American national pilgrimage took shape, an author put mediaeval pilgrims in

\footnotetext{
117 American National Pilgrimage pamphlet, 1896.

${ }^{118}$ R. Ellis Roberts, A Roman Pilgrimage (New York: Frederick A. Stokes company, 1911), 4.

119 Jesse Albert Locke, “A Recent Convert's Pilgrimage to Rome," The Catholic World, A Monthly Magazine of General Literature and Science, July 1893.

120 “A New Style of Pilgrimage," Christian Advocate, October 21, 1875.

121 “Catholic Pilgrimages," The Monitor, September 7, 1895.
} 
stark contrast to modern travelers, reminding readers that

the time was when a pilgrimage meant far more than it does now; when the pilgrim with staff and scrip, went forth with dim hope of a safe return, when the prospect before him was that of long and weary trial, as he toiled....not knowing how he should be fed, or where he should sleep....for months and years, and always apprehensive that death might overtake him on his journey, and that his bones would be left to bleach on the desert, or under the burning Syrian sun. ${ }^{122}$

"American pilgrimage," the author continued, "is a pilgrimage in nothing but the name. It is an anachronism....It is scarcely up to the level of a trip to Colorado, or to the Yellowstone with its natural wonders." 123

American Catholics debated whether or not modern pilgrimage could be considered authentic, using the elements of medieval pilgrimage as the bar. Some authors argued that the physical suffering that mediaeval pilgrims experienced took different forms within modern pilgrimage. Describing his experience on pilgrimage, Jesse Locke explained, "with the very best management and organization, one could scarcely travel together in one company, even in these days, without there being quite enough to try the temper and endurance." He described their struggles. "Sometimes we had extremely uncomfortable railway carriages, sometimes friends and families were separated and lost one another; luggage disappeared; one could perhaps find no room at a hotel, and was obliged to sleep where he could." ${ }^{24}$ Another author proclaimed "I am sure no mediaeval pilgrim, with the good road under his own, or his horse's feet suffered half our anguish in the miserable end of the journey: so, rather cold and cross and hungry." ${ }^{125}$ When recounting a pilgrimage to Lourdes, Richard Clarke explained "mortification has not ceased to be, but has taken a new form - bodily penances do not cost very much when compared with the

\footnotetext{
122 "American Pilgrimage to Rome," New York Evangelist, February 26, 1874.

${ }^{123}$ Ibid. In See America First, Marguerite Shaffer demonstrates how sites such as Yellowstone became the American ideal of authenticity.

${ }^{124}$ Locke, "A Recent Convert's Pilgrimage to Rome."

${ }^{125}$ Roberts, A Roman Pilgrimage, 5.
} 
interior desolation and anguish of soul that the greater strain of modern life seems to bring with it." ${ }^{126}$ Later in his account he wrote,

we have no wish to depreciate the mediaeval pilgrims, but we are anxious that the modern pilgrim should not be unduly disparaged, or treated as if he scarce deserved the name, because, forsooth, he is whirled along at railroad pace, and takes a day and a half instead of a month and a half over his journey. ${ }^{127}$

The tensions that existed within what elements constituted a true pilgrimage or pilgrimage site reflects the desire American Catholics had for an authentic experience. Pilgrims were interested in connecting their journey to medieval pilgrimage because by doing so, they were engaging in the history and traditions of the Catholic Church. The importance American Catholic authors gave to the distinction between real pilgrimages and leisurely travel is due to the fact that Protestants were increasingly participating in pilgrimages at the turn of the century. By participating in authentic pilgrimage, pilgrims were identifying as authentically Catholic.

The desire American Catholics had to distinguish their sacred travel from that of their Christian brethren is evident in their distinction between Protestant pilgrimage revival and real pilgrimage revival. An article from October 21, 1893 stated, "in England the [pilgrimage] revival takes the material and practical — the non-supernatural—-form that might be alone expected from English Protestants." 128 The English pilgrims are "not to be troubled by thoughts of sin and penitence. Theirs is not to be pilgrimages of honor to God and expiation for man's offences." Instead, "they will go by special and luxurious trains to visit at their leisure some places famous in history and others of 'human and contemporaneous interest."' On the other hand, a Catholic pilgrimage meant "journeying to some shrine, made holy....by perhaps thousands of years of gathered associations and traditions." The author was sure to differentiate the "real revival of

\footnotetext{
${ }^{126}$ Clarke, Lourdes, Its Inhabitants, Its Pilgrims and Its Miracles, 53.

127 Ibid., 55.

128 “The Revival of the Pilgrimage," Sacred Heart, October 21, 1893.
} 
real pilgrimages" that the Catholic world had experienced in the past few years. ${ }^{129}$ Another article describing a religious festival in France claimed that "Protestantism can show no parallel for the simple and lively faith that is exhibited [here]."130

American Catholic authors critiqued Protestant pilgrimage for its lack of piety and its conflation with secular leisurely travel. On January 28, 1893 a reporter noted that there was to be a Protestant pilgrimage to Rome the following spring. The article described the pilgrimage as having a "total absence of tact and fitness" due to its "blundering blindness to the proprieties and associations of such a peculiarly Catholic celebration. [I]t is essentially modern, Protestant and John Bullish."131 On June 15, 1895, The Sacred Heart Review published an article on Presbyterians that made a pilgrimage to the location of the first American Presbyterian church. According to the author, "our Presbyterian friends [were] copying a good old Catholic custom."132 Later in the fall, another article reported that a group of Congregational Protestants became "infected with the prevalent pilgrimage spirit" and went on pilgrimage to England where their Puritan ancestors originated. ${ }^{133}$ In regard to their itinerary, the article noted that there were no particular shrines mentioned, nor any saints. An article from August 8, 1896 chastised "our Protestant friends who have recently taken to copying the good old Catholic practice of making pilgrimages" as they seemed to have lost sight of the pious purposes of the practice. ${ }^{134}$ When writing about contemporary Catholic pilgrims, American Catholic authors desperately sought to set them apart from what they perceived as faux Protestant pilgrimage. This is why there was much debate surrounding luxurious accommodations and transportation incorporated within

\footnotetext{
129 “The Revival of the Pilgrimage," Sacred Heart, October 21, 1893.

130 “A Festival in Provence," Sacred Heart, April 23, 1892.

131 "Protestant Pilgrims," Sacred Heart, January 28, 1893.

132 "A Presbyterian Pilgrimage," Sacred Heart, June 15, 1895.

133 “A Congregational Pilgrimage," Sacred Heart, November 16, 1895.

134 “The Most Successful Protestant Pilgrimage," Sacred Heart, August 8, 1896.
} 
American Catholic pilgrimage.

American Catholic authors were also reacting against the fact that the travel-book marketplace to holy sites such as the Holy Land and Rome was almost exclusively Protestant in the nineteenth century. ${ }^{135}$ This is most likely because Protestants tended to have the means to travel. These guidebooks did not provide information important for Catholics such as places in which indulgences were granted or basilicas significant to Catholic history. Father Eugene Vetromile, a missionary among the Etchemin Indians of Maine, published his own travel account of Europe and the Holy Land in 1871 to offer a Catholic perspective on traveling abroad. He expressed his frustration with Protestant travel guides, asserting that they

frequently misrepresent, perhaps unintentionally, the real customs of Catholic countries, and sneer at the practices, manners, religion, etc of Catholic nations. Their narratives entirely suppress or barely mention the beauty, progress, civilization, and philanthropy which the Catholic religion develops, and the good which it operates throughout the world. ${ }^{136}$

The concern American Catholic authors had with defining what distinguished true pilgrimage from religious or secular tourism stemmed from a desire to cultivate a unique Catholic identity rooted in religious tradition and connected to a global network. According to historian James Hennesey, American Catholics strove to legitimate their position in the American political and religious scene. ${ }^{137}$ Devotional Catholicism, including practices such as pilgrimage, became a means of social identity distinct from Protestant society. ${ }^{138}$ The "sense of the nearness of the spiritual world" present in Catholic private devotions, public worship, and pilgrimage characterized the faithful. ${ }^{139}$ Protestants rejected the existence of modern miracles, so the miracles associated with recognized pilgrimage sites separated Catholic spirituality from that

\footnotetext{
${ }^{135}$ Klatzker, "American Catholic Travelers to the Holy Land 1861-1929," 59.

${ }^{136}$ Vetromile, Travels in Europe, Egypt, Arabia Petrcea, Palestine and Syria, 13-14.

${ }^{137}$ Hennesey, American Catholics, 198.

138 Dolan, The American Catholic Experience, 238.

139 Taves, The household of faith, 48.
} 
of Protestants. American Catholics were trying to define their identity within a country dominated by Protestants.

Nationally organized pilgrimage also allowed for the formation of an American identity within the universal Church. Gábor Barna has written about how pilgrimage strengthened Hungarian pilgrims' national identity during the turn of the century. ${ }^{140}$ The same can be said about American pilgrims. Articles and pamphlets regularly included descriptions of American pilgrims gifting the Pope, the head of the universal Church, an American flag, the ultimate symbol of the United States. An article from The Sacred Heart Review, used as the epigraph of this chapter, described the national pilgrimage of 1895, including the fact that the Holy Father expressed his disappointment that the pilgrims did not bring an American flag for the Vatican. The Brooklyn Catholic Young Women's Association remedied the situation by creating two silk flags to be hung as portieres in the passageway leading to the Pope's private apartments. ${ }^{141}$ The pilgrims of the summer of 1896 presented an American flag embroidered in gold to the Holy Father, as did the pilgrims of the summer of $1900 .{ }^{142}$ In 1900, pilgrims also presented the Pope with a monetary offering in a specially designed casket, decorated in the "Papal arms and colors and those of the United States." ${ }^{143}$ Through the gift of the flag, American pilgrims identified themselves as American to their Holy Father, the man they understood to be the vicar of Christ. By showing reverence to the Pope, they embraced their identity as Catholics, but they also desired to be recognized as Americans.

By the early twentieth century, American pilgrims partaking in nationally organized pilgrimages were regularly photographed with the Pope, the American flag in hand (see Figs. 9,

\footnotetext{
140 Barna, "National Pilgrimages, Pilgrim Trains and Identity-Building," 202.

141 "Catholic News and Notes," Sacred Heart, November 2, 1895.

142 Sacred Heart, August 22, 1896; Sacred Heart, September 1, 1900.

143 "Jubilee Pilgrimage," The Catholic Telegraph, June 21, 1900.
} 
10, and 11). These photographs make visible what American pilgrims perceived as their dual identity: an identity as Catholics, standing in the presence of their Holy Father, and an identity as Americans, displaying the stars and stripes. This dual identity is exemplified in a pamphlet for the 1908 pilgrimage to Rome (Fig. 12). On the cover's bottom right corner, the Vatican's seal is prominently displayed, reminding prospective pilgrims of their connection to the universal Church. The seal of the United States sits on the cover's top left corner, prompting prospective pilgrims to acknowledge their allegiance to their country.

Pilgrimage banners, "an essential part of the equipment of pilgrimages," were used in the same way. ${ }^{144}$ Banners identified pilgrimage groups, whether they were formed from parish communities or whole countries. They were particularly useful during religious processions, a common practice during pilgrimages at the turn of the century. Banners were left by American pilgrims in 1889, 1894, 1895, and 1896 in the Holy House at Loretto, in the Basilica at Lourdes, at the Shrine of St Anthony of Padua, and in the Vatican at Rome. ${ }^{145}$ In the winter of 1897 , American pilgrims carried an American flag made of banner silk, embroidered with the badge of the pilgrimage and the year $1897 .{ }^{146}$ They deposited it in the Church of the Holy Sepulchre in Jerusalem, there to remain along "the flags of other nations; a glad and welcome sight to the American tourist of any religious belief, and the symbol of loyalty, faith and devotion to God and our country of the American Catholics and the American Pilgrimage." ${ }^{147}$ Even those who were not participating in the national pilgrimages could donate money towards these banners as votive offerings, allowing them to strengthen their identity as American Catholics through spiritual

\footnotetext{
144 “English Roman Catholic Pilgrimage," New York Times, August 13, 1873.

145 Pfeiffer, First American Catholic Pilgrimage to Palestine, 1889, 94; American National Pilgrimage pamphlet, 1896.

146 Sacred Heart, April 3, 1897.

${ }^{147}$ American National Pilgrimage pamphlet, 1896.
} 
pilgrimage. ${ }^{148}$ Pilgrimage banners were almost always mentioned in pilgrimage accounts. ${ }^{149}$

They allowed outsiders to identify pilgrimage groups and caused pilgrims to identify with their pilgrimage community.

Pilgrim badges were another way in which pilgrims identified as both American and Catholic. Pilgrims of the first American pilgrimage to the Holy Land of 1889 wore silver badges. The front contained a representation of the Crucifixion with the inscription "First American Pilgrimage to the Holy Land, 1889” while the reverse displayed the Sacred Heart of Jesus and Mary, with the name of the pilgrim. ${ }^{150}$ During the winter pilgrimage of 1897 , pilgrims wore pilgrim badges "where they may be readily seen." 151

Pilgrim badges made one part of a community and displayed allegiance to this community. The diocese of Meaux in France went on pilgrimage to Lourdes in the nineteenth century, and each pilgrim sported a brass badge (see Figs. 13and 14). The front of the badge displays Our Lady of Lourdes piously holding her hands in prayer, a rosary dangling from her right arm. The badge's iconography characterized the pilgrims as Catholic, exhibiting devotion to the Virgin Mary. The reverse of the badge reads "Pilgrimage of the diocese of Meaux to Our Lady of Lourdes," identifying the pilgrims as belonging to their diocesan community. ${ }^{152} \mathrm{~A}$ pilgrim badge from the diocese of Arras in France depicts similar iconography (see Figs. 15 and 16). Engraved on the front is Our Lady of Lourdes shown in profile, a familiar image to the contemporary faithful and markedly Catholic. The back labels the pilgrim as part of the diocese

\footnotetext{
${ }^{148}$ American National Pilgrimage pamphlet, 1896.

${ }^{149}$ Vetromile, Travels in Europe, Egypt, Arabia Petrcea, Palestine and Syria; D. J. Sheehy, Notes on the IrishCanadian Pilgrimage and Addresses (Brooklyn: Nolan Bros., 1892); Pfeiffer, First American Catholic Pilgrimage to Palestine, 1889; Clarke, Lourdes, Its Inhabitants, Its Pilgrims and Its Miracles. Banners were also a staple of American Historical Pageantry during the period according to David Glassberg (American Historical Pageantry: The Uses of Tradition in the Early Twentieth Century (Chapel Hill: University of North Carolina Press, 1990), 16). ${ }^{150}$ Pfeiffer, First American Catholic Pilgrimage to Palestine, 1889, 1.

${ }^{151}$ American National Pilgrimage pamphlet, 1896.

${ }^{152}$ My own translation. Original is "Pélerinage du diocese de Meaux à N. D. de Lourdes."
} 
of Arras. Badges both distinguished Catholic pilgrims from Protestant pilgrims and identified them as part of a particular community (whether parish- or nationally-based).

The American Chapel at Lourdes was a site of pilgrimage that reinforced pilgrims' identities both as Catholics and as Americans. At the end of the nineteenth century, a chapel in the Church of the Rosary in Lourdes was set aside for the United States. Americans were responsible for funding the completion of the chapel, and Mr. and Mrs. Francis H Throop of Brooklyn (organizers of the 1896, 1897, and 1898 national pilgrimages) took the lead in raising the funds. Those who provided votive offerings of a dollar or more received a medal of Our Lady of Lourdes blessed at the Grotto. ${ }^{153}$ The American Chapel was located in what Catholics considered to be a very sacred space. In the mid-nineteenth century, the Virgin Mary allegedly appeared in a grotto to Bernadette, a poor country girl. At the end of the century, Lourdes was one of the most popular pilgrimage sites for Catholics, and hundreds of pilgrims reported having been miraculously cured there. Lourdes was a quintessentially Catholic sacred space. Partaking in pilgrimage to Lourdes marked groups as identifiably Catholic and apart from Protestant pilgrims. By constructing and decorating a national chapel within the sacred site, pilgrimage organizers were setting space apart specifically for Americans.

At the turn of the century, American Catholics were cruising through the choppy waves of the Atlantic, packing into cramped train cars, and trekking up rocky inclines on route to sacred spaces. They travelled as far as Palestine and as close as Staten Island. The pilgrims knelt in churches, bathed in miraculous springs, adored shriveling relics, thumbed smooth rosary beads, participated in torchlight processions, and approached holy shrines on their knees. Often within the same trip, they visited popular tourist destinations, resided in elegant first-class class hotels,

153 Third Annual American National Pilgrimage, 1896. 
went on excursions to the neighboring countryside, and raided shops for mementos. They brought back statues, blessed medals, rosaries, candles, scapulars, crucifixes, and holy water.

American Catholic authors eagerly sought out to defend "true Catholic pilgrimage" while simultaneously critiquing Protestant attempts to perform the sacred practice. The tension between what was defined as true pilgrimage and leisurely travel is unmistakable within contemporary literature. American Catholics struggled to delineate the required components of pilgrimage, as mass tourism extended its reach to the middle class. Pilgrims used pilgrimage to strengthen their identity as Catholics, setting themselves apart from Protestants. However, they identified themselves as Americans overseas, proudly displaying the stars and stripes as they walked on holy ground. 
List of Figures

ATERICAN NATIONAL PILGRIMAGES to tbe Бoly Cand and Rome,

by specially chartered steamer Feb'y 5,1595 . including Cruise of the mediterrancan

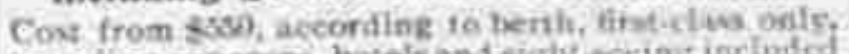
troveling expenics, botelshand sighi -ocios iocionfed HOLY WEEK \& EASTER IN ROME.

Fordetall, prougrim anit information, antd-cos. fRANCIS H. THROOP, IIt Broadway, N. Y. Or PA PHICK DOSAIIOK, 69 Washington st. Bonten, Geveral Acent fer Sew. Englast.

Figure 1: Advertisement for the American National pilgrimage to the Holy Land and Rome. Taken from The Sacred Heart Review, December 4, 1897.

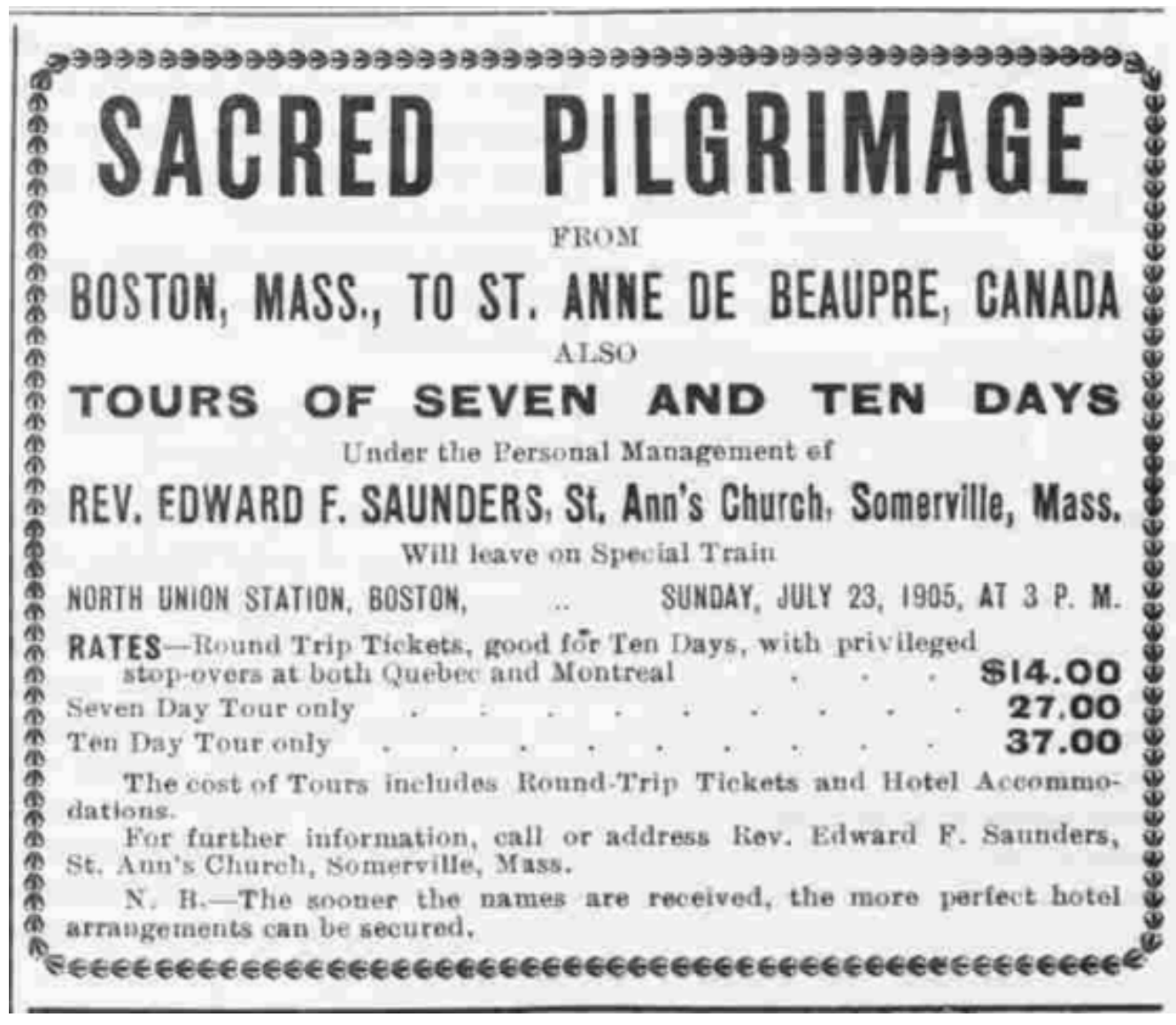

Figure 2: Advertisement for pilgrimage to St Anne de Beaupré. Taken from The Sacred Heart Review, June 10, 1905. 


\section{Pilgrimage to St. Anne de Beaupré}

By Bteamer, Jnly 16, Oralains Fatern Bhores of Canada and the Plotureegue Bt. Inwreace By requeat a Unlque and Delightful Tour has been arranged in connectlon with thia Pligrimnke for a month's travel to Include Quebec and environs, Montreal. Thousand Islands, Rapids, tho far tamed Saguenay. Prince Edward Ialand, Gaope Coast, Bras d'Or Lakea Country, Antigoniah, Halifax, Bay of Fundy, Land of Evangoltab, ota. Farly booking oxsentinl to securo cholee of staterooms

Arrangements made for leaving from Boston-connecting with steamer at Elallax For Detalle of Tour Addrese James Hoyt Miller THE GOTHIC TOURS, Stamford, Conn.

Figure 3: Advertisement for pilgrimage to St Anne de Beaupré. Taken from America, June 25, 1921. 


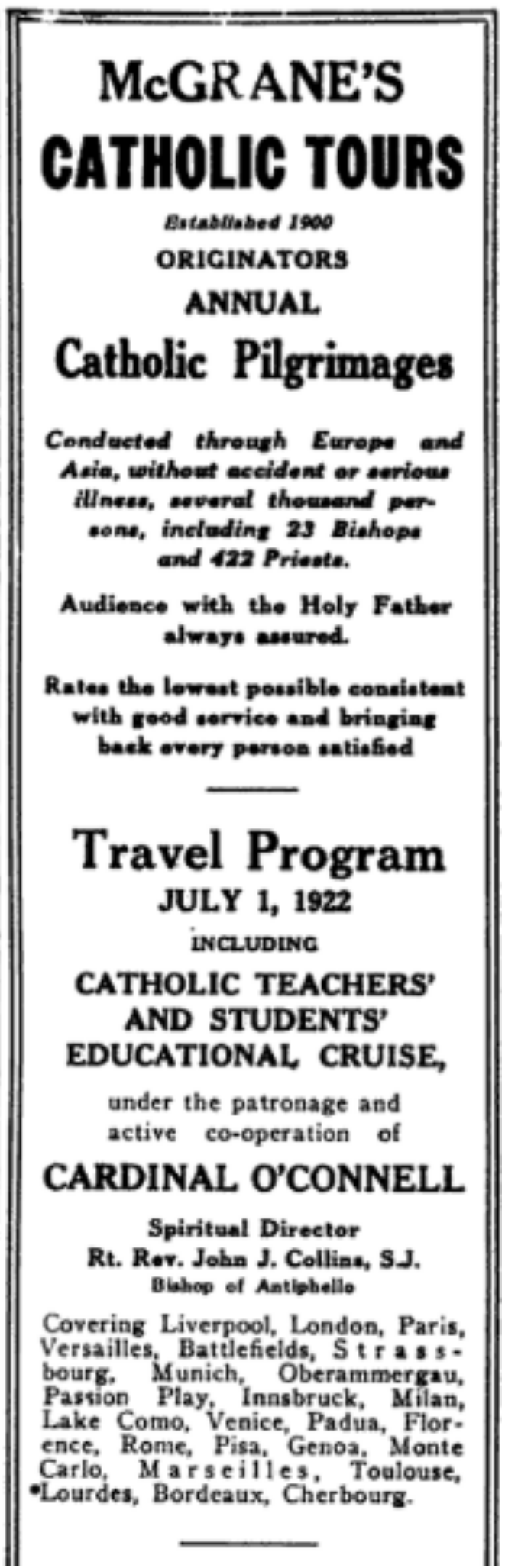

Figure 4: Advertisement for a pilgrimage to Europe. Taken from America, April 22, 1922. 


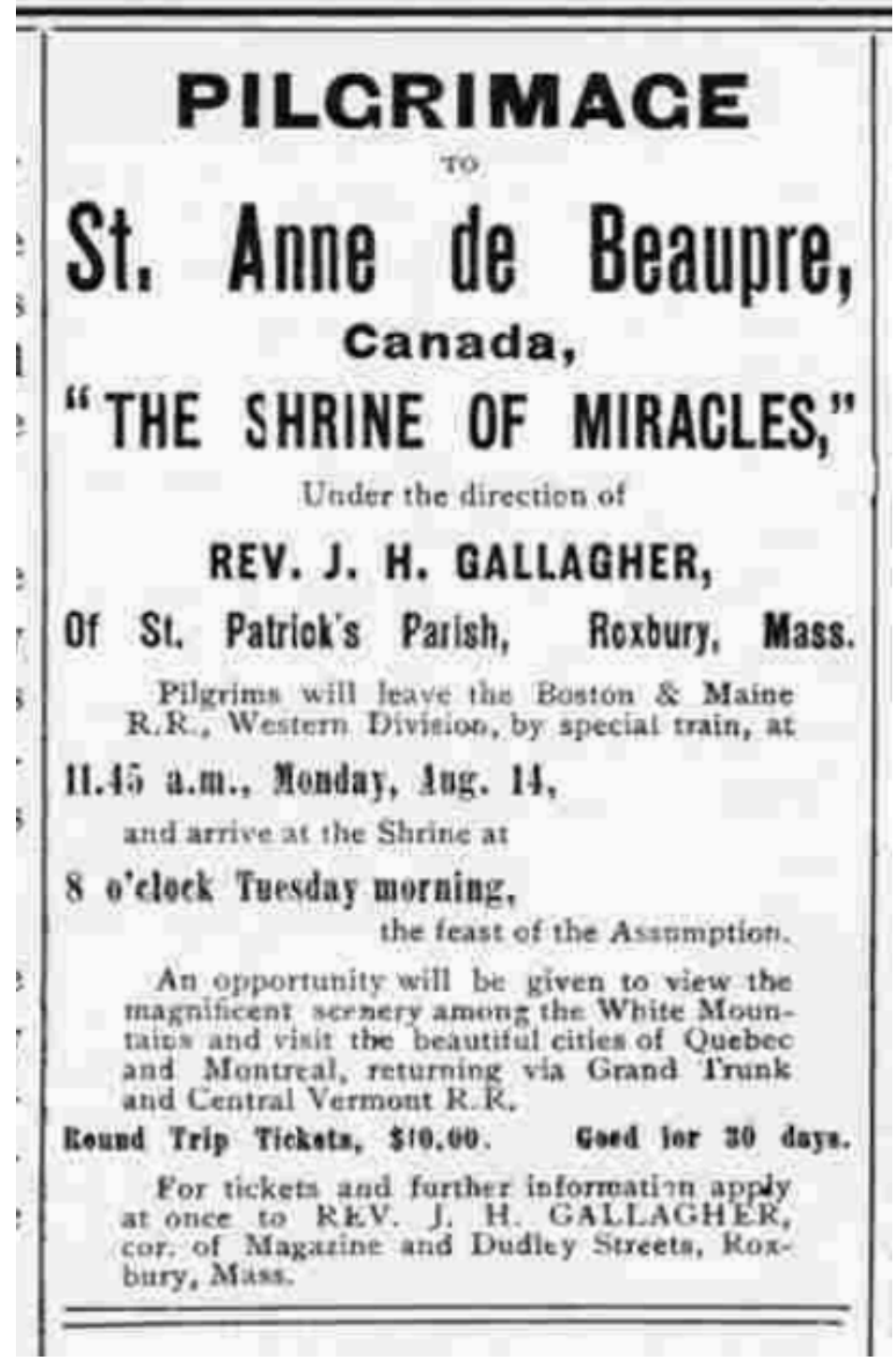

Figure 5: Advertisement for pilgrimage to St Anne de Beaupré. Taken from The Sacred Heart Review, July 22, 1893.

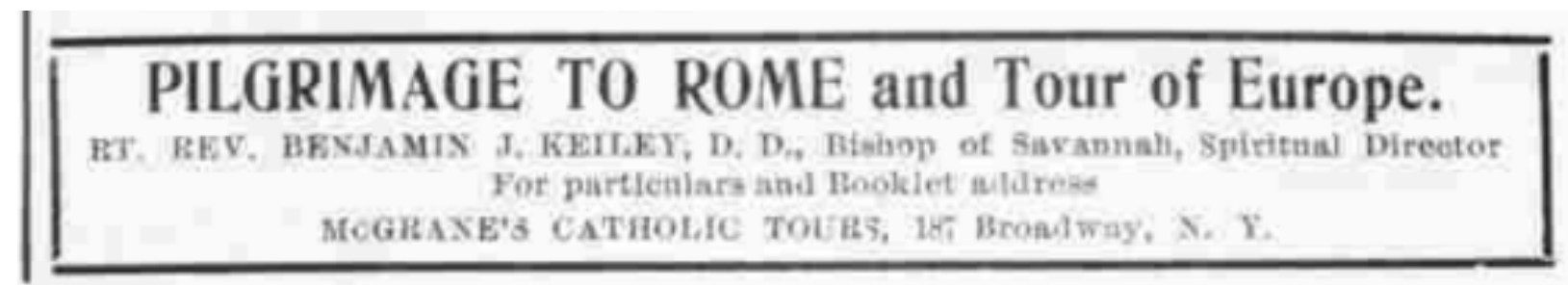

Figure 6: Advertisement for pilgrimage to Europe. Taken from The Sacred Heart Review, February 18, 1905. 


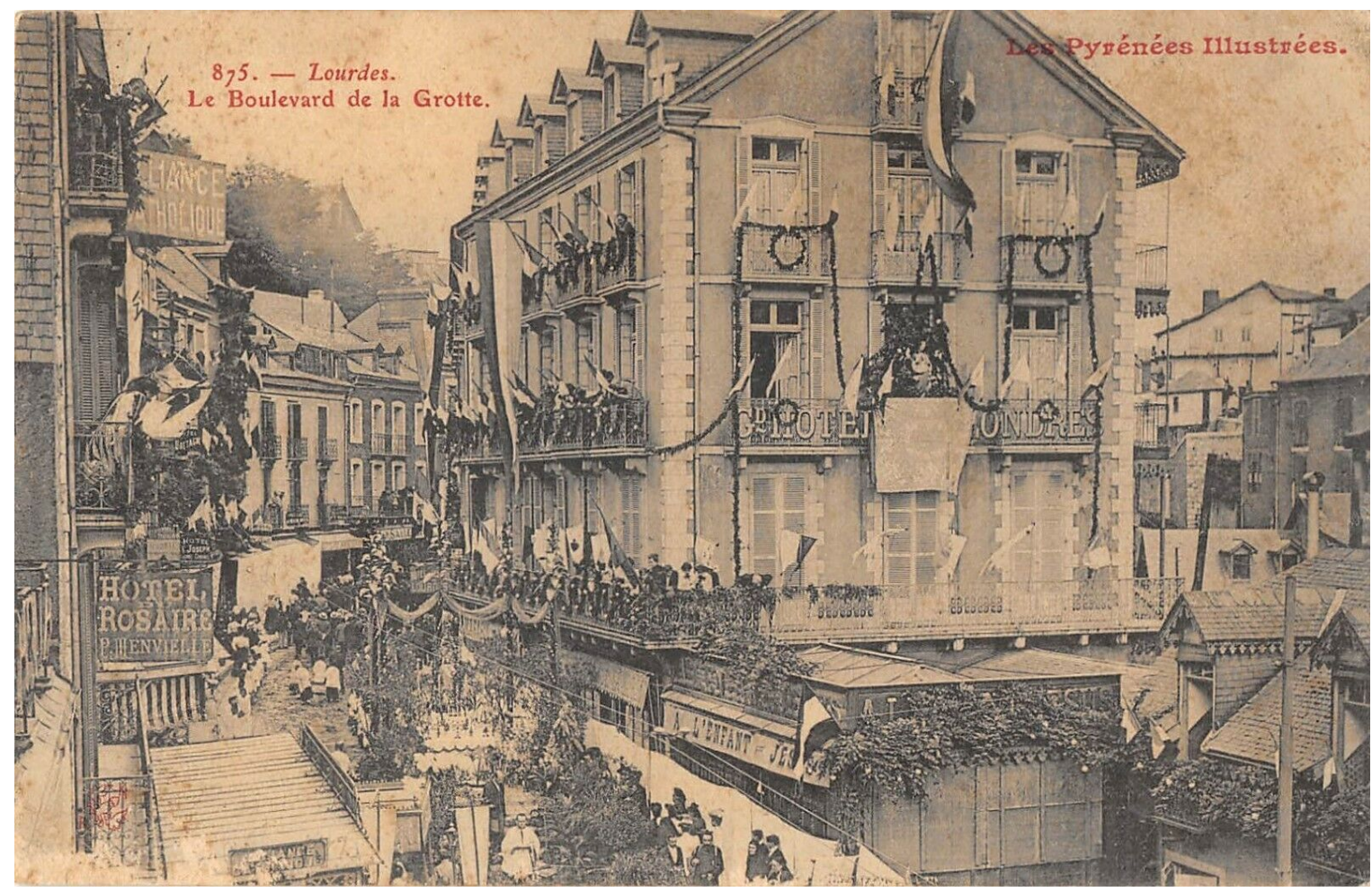

Figure 7: "Lourdes le Boulevard de la Grotte," Lourdes postcard, c. 1900, eBay, accessed April 24, 2020, https://www.ebay.fr/itm/CPA-65-LOURDES-LE-BOULEVARD-DE-LAGROTTE/173735279420?_trkparms=aid\%3D1110006\%26algo\%3DHOMESPLICE.SIM\%26ao \%3D1\%26asc\%3D20131003132420\%26meid\%3D1617377c6ed242dea3694c101c2d750a\%26pi d\%3D100005\%26rk\%3D5\%26rkt\%3D12\%26mehot\%3Dpf\%26sd\%3D133471968794\%26itm\% 3D173735279420\%26pmt\%3D1\%26noa\%3D0\%26pg\%3D2047675\%26algv\%3DSimplAMLv5 PairwiseWebWithBBEV1Filter\&_trksid=p2047675.c100005.m1851. 


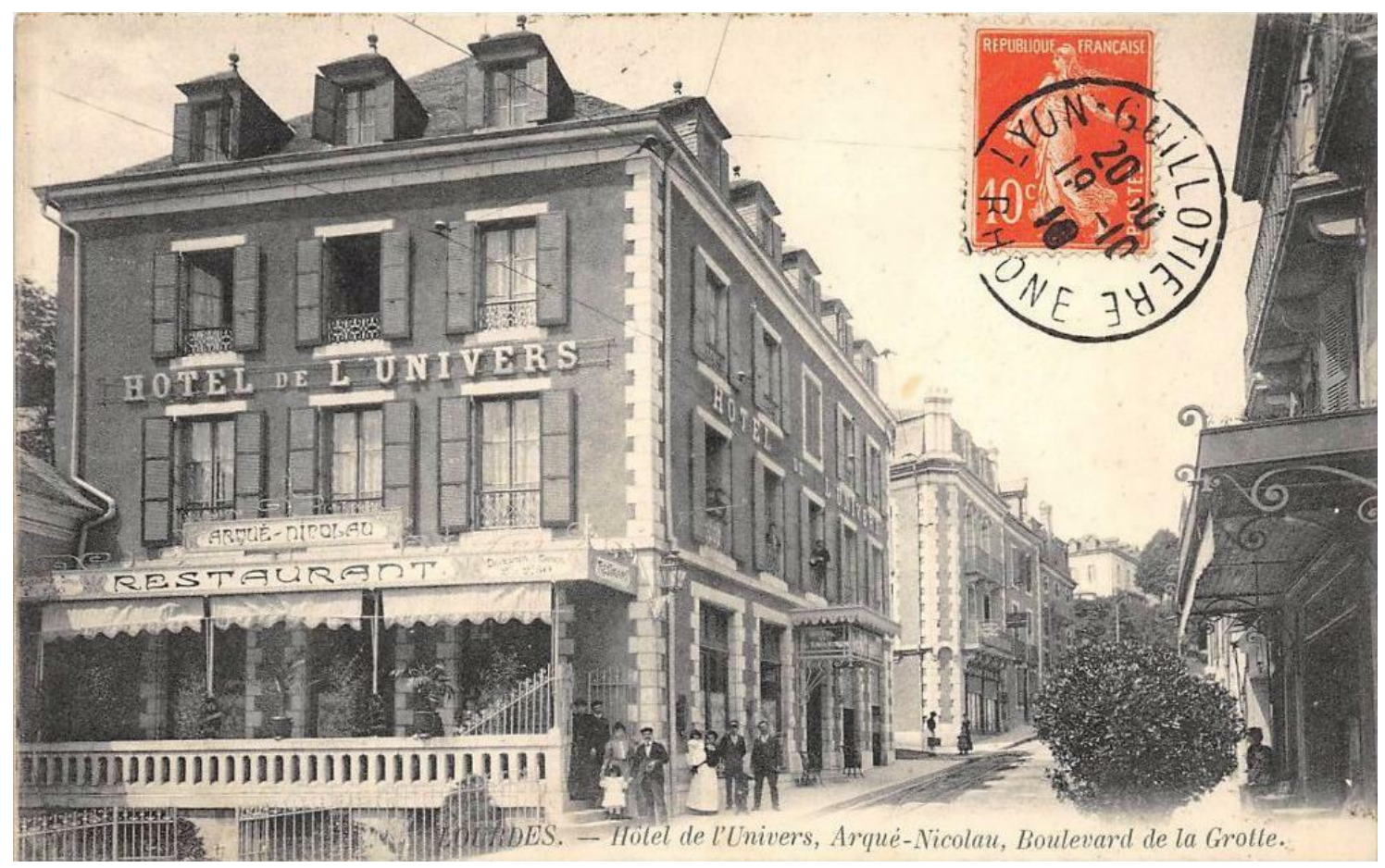

Figure 8: "Lourdes Hotel de l'Univers Arque Nicoleau Boulevard de la Grotte," Lourdes postcard, c. 1900, eBay, accessed April 24, 2020, https://www.ebay.fr/itm/CPA-65-LOURDESHOTEL-DE-LUNIVERS-ARQUE-NICOLEAU-Bd-DE-LAGROTTE/172485790656? trkparms=aid\%3D1110012\%26algo\%3DSPLICE.SOIPOST\%26ao\% 3D1\%26asc\%3D20200420083544\%26meid\%3De889ea3f66c04709bcd21c47e7d68f69\%26pid\% 3D100008\%26rk\%3D1\%26rkt\%3D12\%26sd\%3D173735279420\%26itm\%3D172485790656\%2 6pmt\%3D1\%26noa\%3D0\%26pg\%3D2047675\%26algv\%3DPromotedSellersOtherItemsV2\&_tr $\mathrm{ksid}=\mathrm{p} 2047675 . \mathrm{c} 100008 . \mathrm{m} 2219$. 


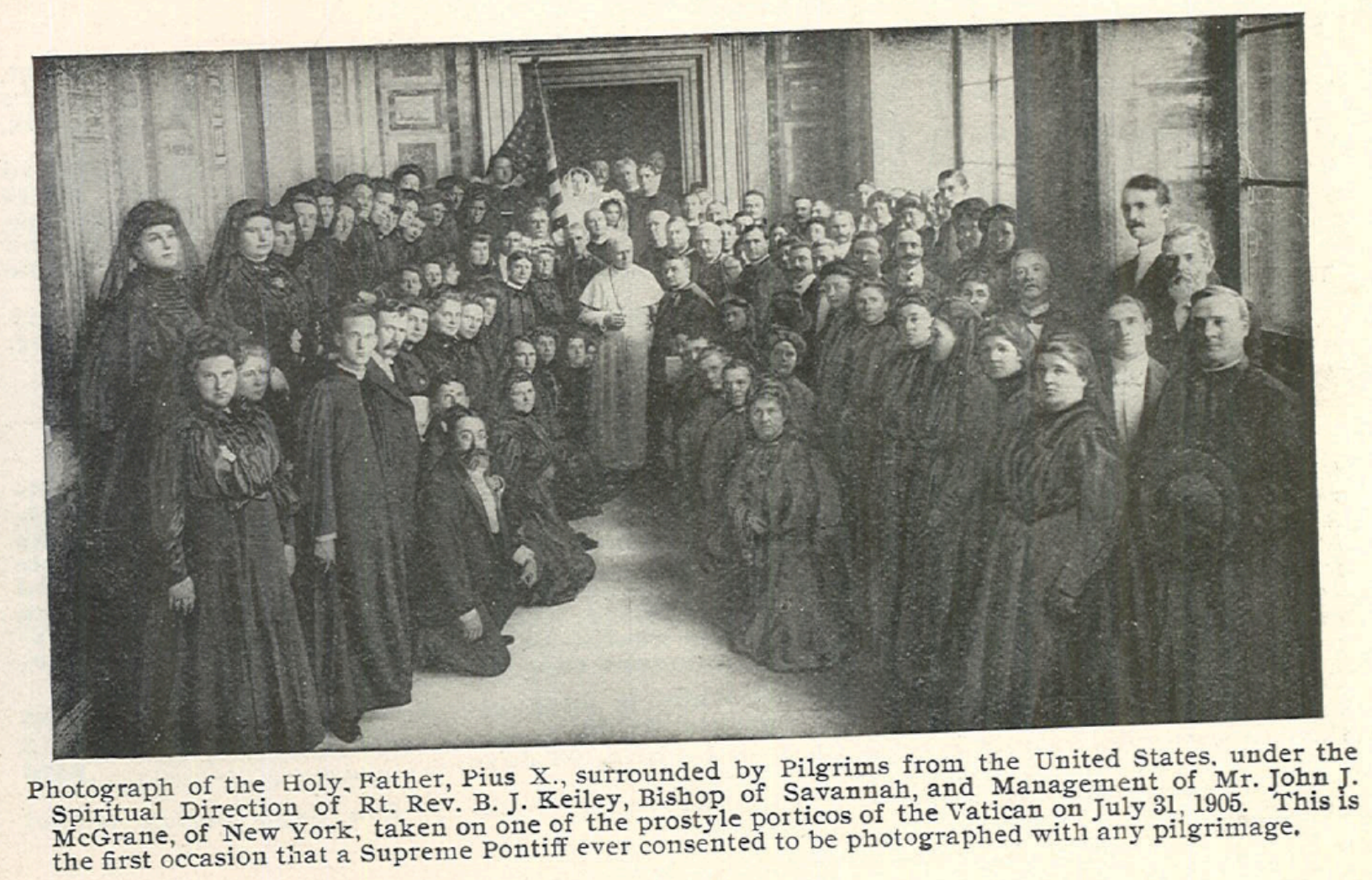

Figure 9: Photograph of the 1905 American national pilgrimage found in Holy Father's Golden Jubilee, Pilgrimage to Rome and Grand Tour of Europe. 1908. P002.0496. Printed Ephemera. Catholic Historical Research Center of the Archdiocese of Philadelphia, Philadelphia, PA. 


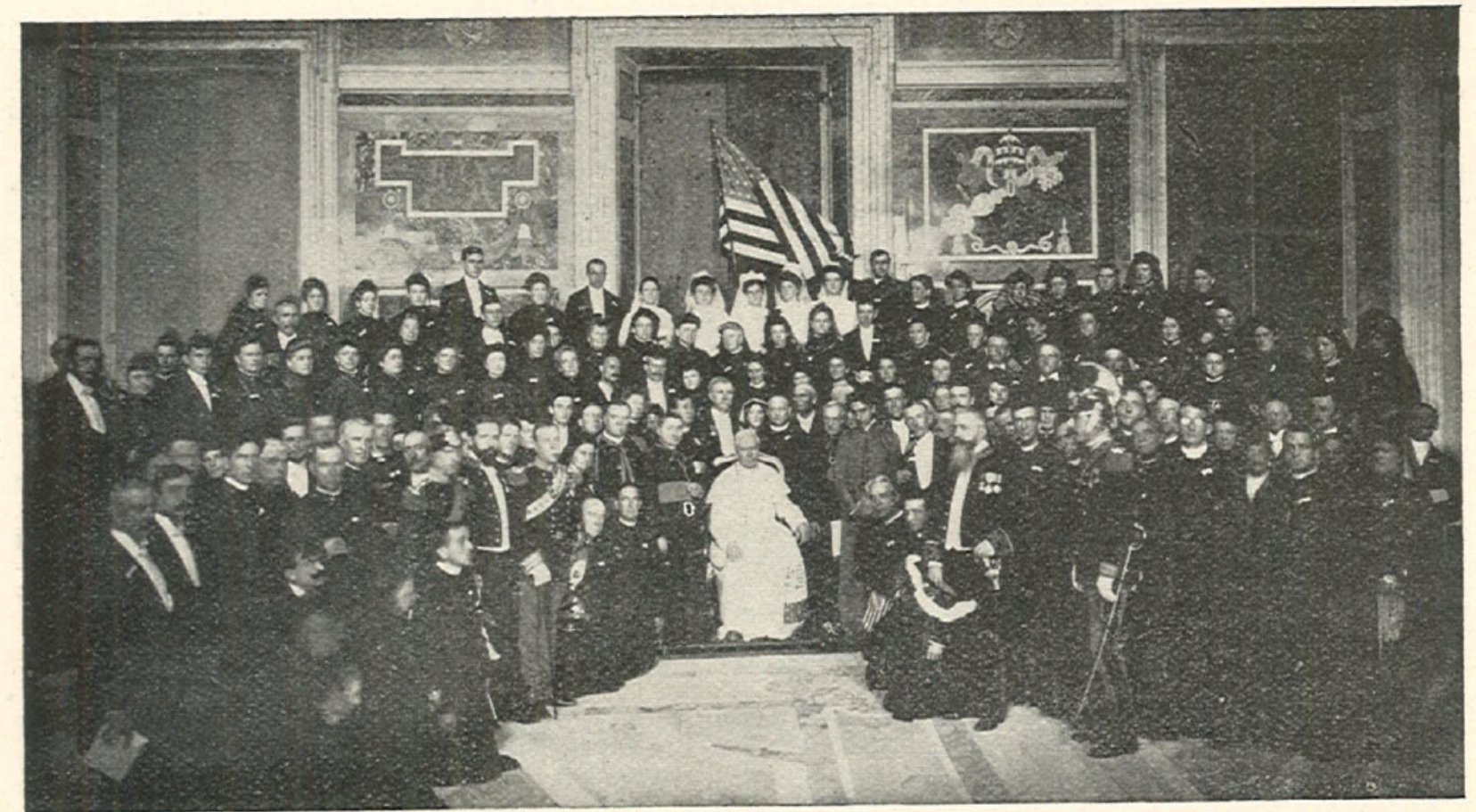

Photograph of the Holy Father, Pius X, surrounded by Pilgrims from the United States, under the spiritual direction of the Rt. Rev. Henry Gabriels, D.D., Bishop of Ogdensburg. and the business management of Mr. John J. McGrane, taken in the Clementine Hall of the Vatican, July 31, 1906.

Figure 10: Photograph of the 1906 American national pilgrimage found in Holy Father's Golden Jubilee, Pilgrimage to Rome and Grand Tour of Europe. 1908. P002.0496. Printed Ephemera. Catholic Historical Research Center of the Archdiocese of Philadelphia, Philadelphia, PA. 


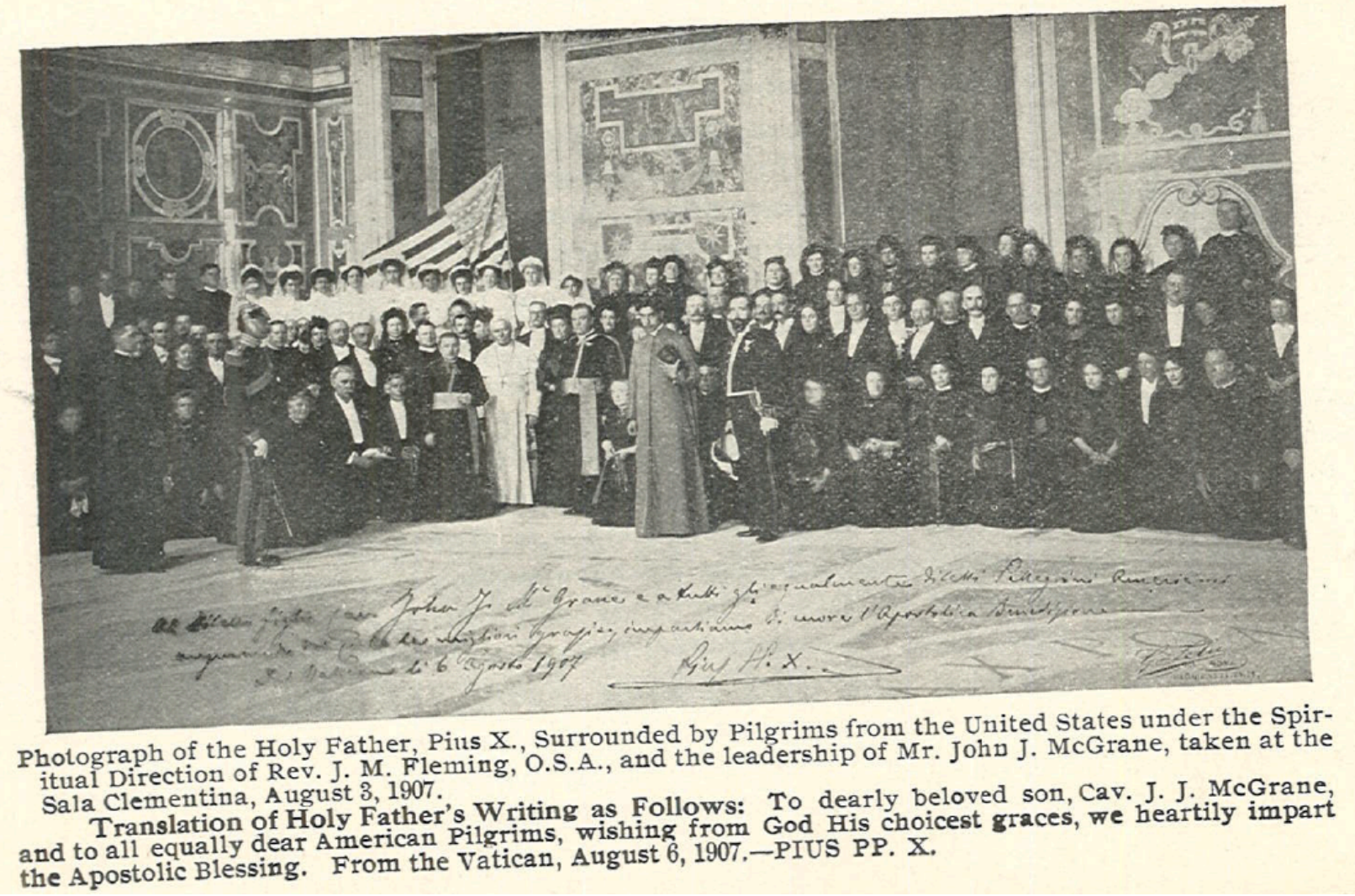

Figure 11: Photograph of the 1907 American national pilgrimage found in Holy Father's Golden Jubilee, Pilgrimage to Rome and Grand Tour of Europe. 1908. P002.0496. Printed Ephemera. Catholic Historical Research Center of the Archdiocese of Philadelphia, Philadelphia, PA. 


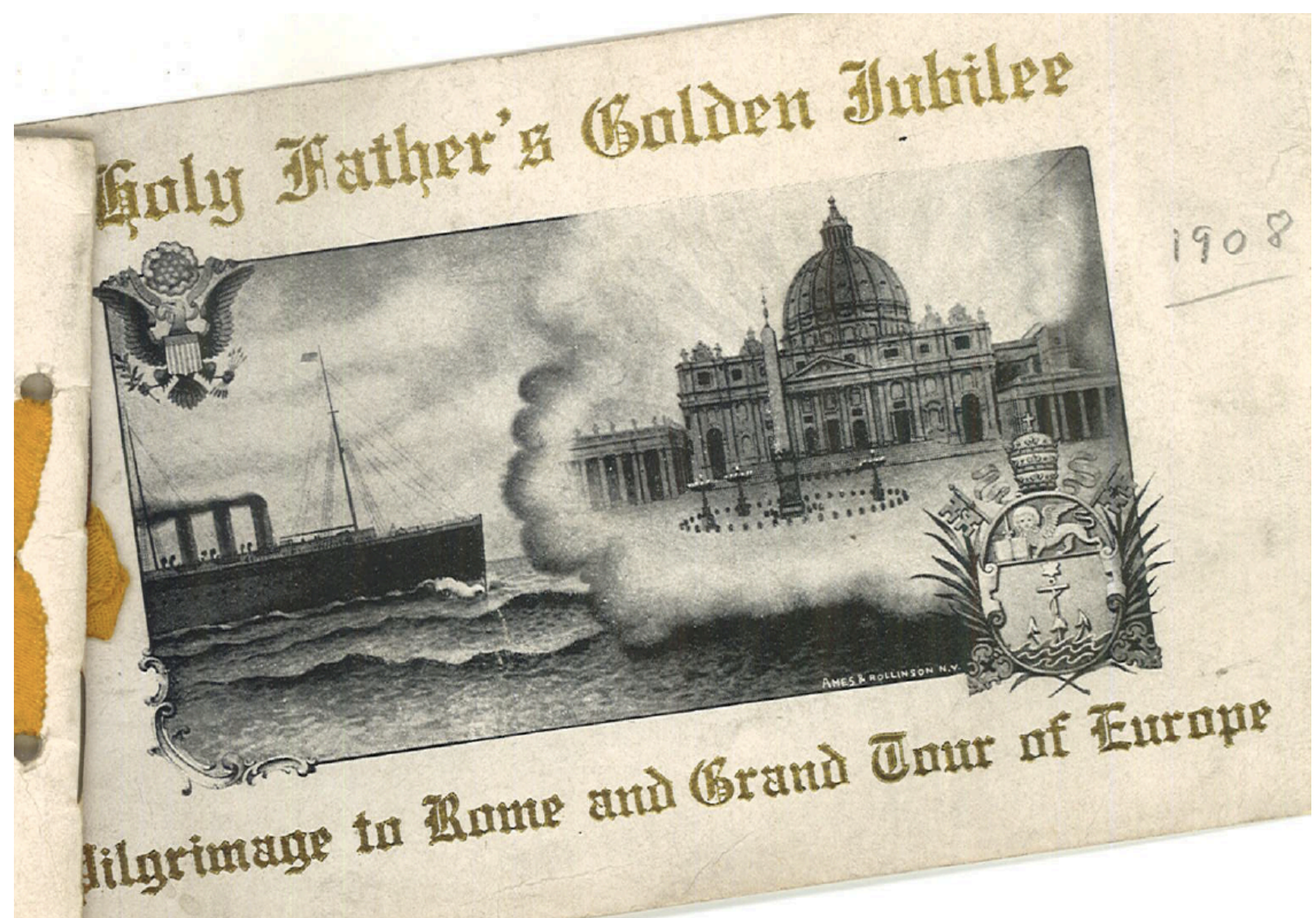

Figure 12: Holy Father's Golden Jubilee, Pilgrimage to Rome and Grand Tour of Europe. 1908. P002.0496. Printed Ephemera. Catholic Historical Research Center of the Archdiocese of Philadelphia, Philadelphia, PA. 


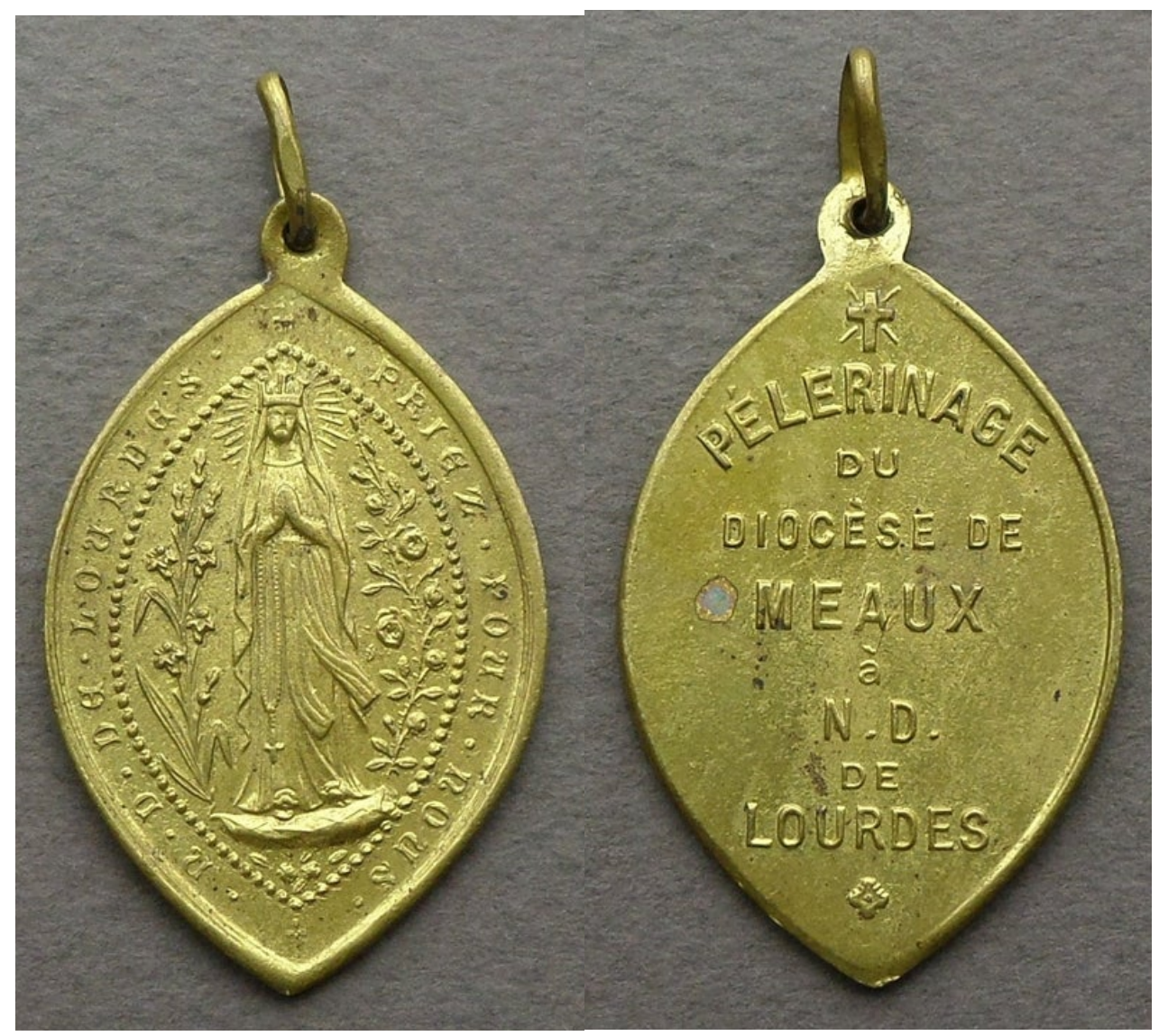

Figures 13 and 14: Pilgrim badge for Diocese of Meaux to Lourdes, c. $19^{\text {th }}$ century, brass, $43 \mathrm{x}$ 37 mm, Etsy, accessed April 24, 2020, https:/www.etsy.com/ca/listing/760247242/french-brassreligious-during-

virgin?ga_order=most_relevant\&ga_search_type=all\&ga_view_type=gallery\&ga_search_query $=$ catholic+pilgrimage $\&$ ref $=$ sr_gallery-11-17\&organic_search_click $=1$. 


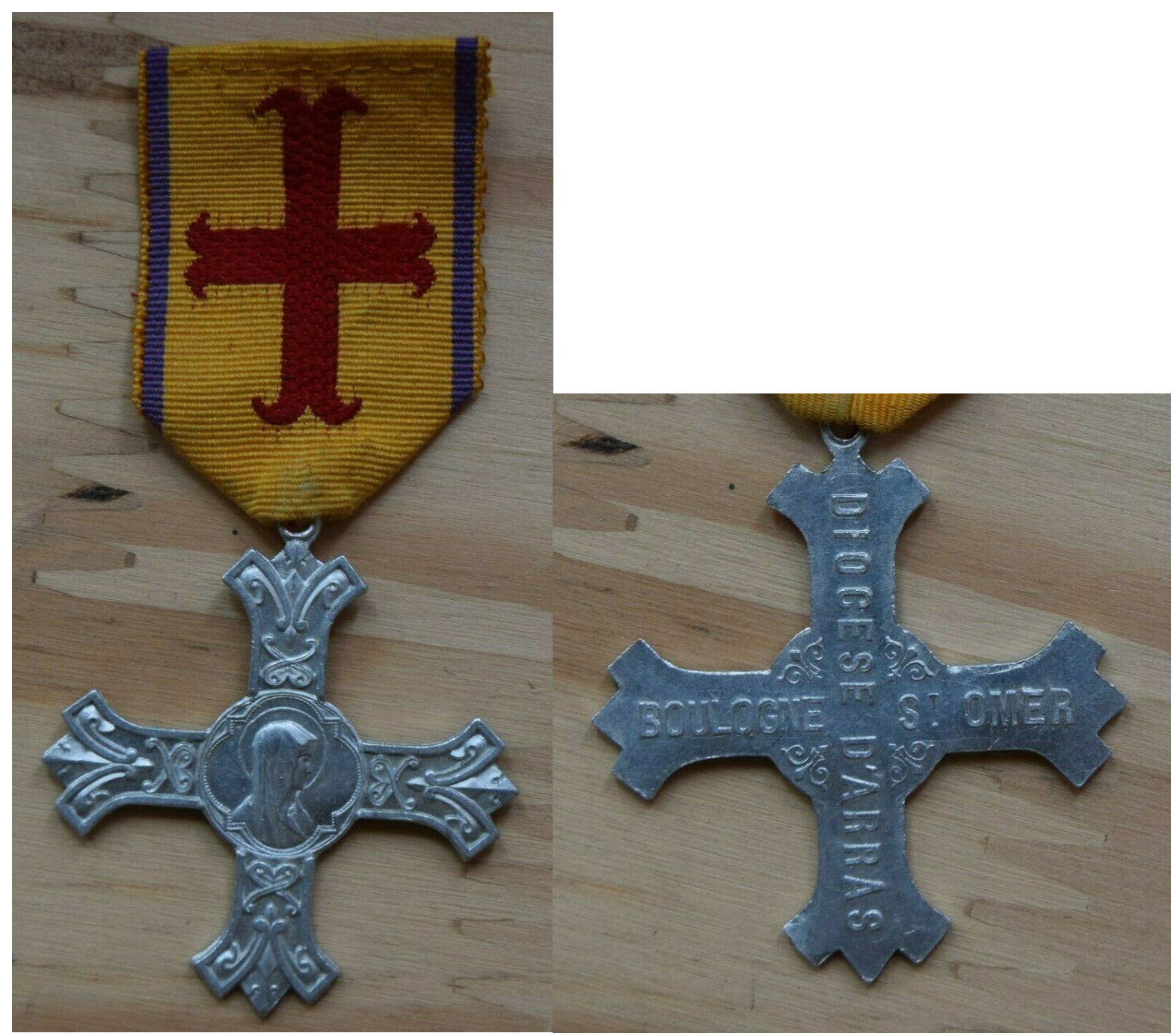

Figures 15 and 16: Pilgrim badge for Diocese of Arras to Lourdes, material unknown, c. $19^{\text {th }}$ century, eBay, accessed April 24, 2020, https:/www.ebay.fr/itm/insigne-religieux-medaillereligieuse-pelerinage-catholique-diocese-

dARRAS/392745323633?_trkparms=aid\%3D1110001\%26algo\%3DSPLICE.SIM\%26ao\%3D1 \%26asc\%3D20131231084308\%26meid\%3Dfd190f5977d84edbaf43dc683c833753\%26pid\%3D1 00010\%26rk\%3D5\%26rkt\%3D12\%26sd\%3D353029729081\%26itm\%3D392745323633\%26pm t\%3D0\%26noa\%3D1\%26pg\%3D2047675\&_trksid=p2047675.c100010.m2109. 


\section{CHAPTER TWO}

Pious Preservation:

Safeguarding and Interpreting Tangible Heritage through Pilgrimage

American Catholics believed that pilgrimage sites were divinely appointed, but these spaces still required constant care to sustain the buildings and the opportunity for pilgrimage for future generations. Cathedrals and churches dating back centuries had to be cleaned and maintained. The Church gathered relics and placed them in elaborate reliquaries for future devotion. Both lay people and members of the clergy established new sites of pilgrimage at the turn of the twentieth century, hoping pilgrims would come in droves to experience the sacredness of the locale. Sometimes holy sites were rediscovered through archaeological projects, inaugurating a new destination for pilgrimage. In an effort to authenticate an encounter with the Divine, clergy members assembled manuscripts and testimonies as well as material formerly used by a revered figure, forming small archival collections at pilgrimage sites. Pilgrims were aware of the history intricately interwoven with these sacred places and objects. Guides took pilgrims on tours of pilgrimage sites, interpreting the space's history, artwork, and relevance. Pilgrims meandered through cathedrals and catacombs, reading biblical stories, saints' lives, and the history of the locale from the art decorating the walls. This interpretation was not reserved for those who were able to go on physical pilgrimage, but rather was taught to American Catholics by way of educational lectures and pilgrimage literature. Through pilgrimage at the turn of the twentieth century, members of the Catholic Church continued this practice of preserving and interpreting tangible heritage for future generations.

Historic preservation has grown and developed as a field throughout the twentieth and into the twenty-first century. Heritage organizations such as UNESCO and federal governments 
have established lists of recognition for historic places. Public historian Thomas Cauvin has described the aims of historic preservation as "preserving the past for future generations." ${ }^{1}$ Lay people and clergy members were doing just that, hundreds of years before the establishment of modern heritage organizations. By caring for pilgrimage sites, they were participating in historic preservation.

Pilgrimage guidebooks and newspaper articles frequently noted the restoration and preservation work done on pilgrimage sites, both in the past and in contemporary times. ${ }^{2}$ In 1805, Pope Pius VII restored and strengthened the edifice of the Coliseum on the eastern side. ${ }^{3}$ Cardinal Guibert, the Archbishop of Paris, oversaw the renovation of San Giovanni in Oleo in Rome, in 1873. The renovation was accomplished "without changing a line of the architecture or of the paintings," indicating a desire to not only maintain the site, but also retain its architectural features. ${ }^{4}$ In the spring of 1894 , a number of Spanish pilgrims who worked as stonemasons did three days' work on some of the buildings on Vatican grounds, giving Italian workmen three days of vacation. ${ }^{5}$ The faithful were aware of the importance of preservation, and they noted the condition of pilgrimage sites in their accounts. ${ }^{6}$ Pilgrims were asked to take caution when visiting historic sites. In the Cathedral of Siena, pilgrims walked upon a wooden flooring that

\footnotetext{
${ }^{1}$ Thomas Cauvin, Public History: A Textbook of Practice, (New York: Routledge, Taylor \& Francis Group, 2016), 55.

${ }^{2}$ The Church of St Sixtus II in Rome was restored by Pope Innocent III in 1200, and Nicholas V restored a sixth century church, the church of St Teodoro in Rome, in 1450 (P. J. Chandlery, Pilgrim Walks in Rome: A Guide to its Holy Places (New York: The Messenger, 1903), 228, 282).

${ }^{3}$ Chandlery, Pilgrim Walks in Rome, 207.

${ }^{4}$ Eliza Allen Starr, Pilgrims and Shrines (Chicago: Eliza Allen Starr, 1885), 74.

${ }^{5}$ Sacred Heart, May 26, 1894.

${ }^{6}$ At the shrine of Our Lady of the Hermits in Switzerland, a pilgrim remarked that the old monastery was "in a wonderful state of preservation" and the fact that neighboring churches with discolored facades and artistic mural paintings would be "priceless" "portions of mediaeval keeps" if "carefully restored" ("Switzerland's Holy Town," Sacred Heart, March 17, 1894). A pilgrim visiting the shrine of Our Lady of Good Counsel in Italy wrote that the church was "preserved" (Stoddard, Two Celebrated Sanctuaries of the Madonna in Italy, 28). When describing Rome, pilgrim Eliza Allen Starr stated "there is no sign of decay in any of these venerable temples to the ever-living God. Their frescoes may have faded....but the walls preserve their grandeur and strength, and are as unbroken as the traditions which they embody" (Starr, Pilgrims and Shrines, 1).
} 
covered the marble mosaic floor, "too precious for the shuffling steps of the crowd." A few feet of the floor were left bare, in order for visitors to admire its beauty. ${ }^{7}$ Those maintaining the cathedral in Siena were engaging in preventative conservation, as they wished to slow the denigration of the mosaic floor.

The fact that preservation accounts were common in pilgrimage literature of the period demonstrates that American Catholics were interested in the safeguarding of sacred sites. An article in The Sacred Heart Review outlined the various ways in which the Franciscan friars in charge of the restoration of the Holy Land made improvements to historic structures in Palestine. They restored the church of Flagellation, covered the apse of the sanctuary of Bethphage, and surrounded Shepherd's Hill with a strong wall. They also restored a church in Jerusalem to preserve the remains of "a very fine old mosaic" and surrounded the "precious ruins of Capharnaum" with a wall. ${ }^{8}$ American Catholics preserved historic pilgrimage sites within the United States as well. The Church made efforts to rehabilitate the San Antonio missions, hoping to attract pilgrims and visitors to the restored sites. ${ }^{9}$ The Golden Jubilee (fifty-year anniversary) of the Cathedral of the Immaculate Conception in Albany, New York called for a deep clean of the building. The cleaning process took several months and gave "the appearance externally of an entirely new structure." ${ }^{10}$ Additionally, the cathedral's three main doors were renovated for the occasion. ${ }^{11}$

In cases where pilgrimage sites were destroyed in war, fires, or other natural disasters,

\footnotetext{
${ }^{7}$ Starr, Pilgrims and Shrines, 200.

8 "Catholic Thoughts and Events in Foreign Lands," Sacred Heart, October 9, 1897.

${ }^{9}$ Thomas S. Bremer, Blessed with Tourists: The Borderlands of Religion and Tourism in San Antonio (Chapel Hill: University of North Carolina Press, 2004), 64-72.

${ }^{10}$ Souvenir of the Golden Jubilee and Solemn Consecration of the Cathedral of the Immaculate Conception, 1902, NY171, Printed Ephemera, The Catholic University of America, The American Catholic History Research Center and University Archives, Washington, DC, 14.

11 Ibid.
} 
members of the Church desiring to rebuild these structures for future pilgrims sometimes followed the design of the former building. In the sixteenth century, Cardinal Baronius rebuilt Santi Nereo e Achilleo, a church in Rome, taking "the greatest care to preserve the form of the ancient basilica" and all its "precious ornaments were preserved and re-erected." He left an inscription on a slab in the sanctuary asking future clergy members to "increase nothing, diminish nothing, change nothing, but guard piously the re-established antiquity." ${ }^{12}$ When the shrine of Our Lady of the Hermits in Switzerland burnt down in 1798, it "was rebuilt in strict conformity to the ancient plans."13 In other situations, sacred structures were repurposed for secular governments. This was the case for a house in Rome, where the room of St Stanislaus Kostka once stood. The faithful preserved the materials of the room and put it back together in another part of the building near a church, "every pains being taken to reproduce an exact copy of the original room." ${ }^{14}$ Catholics recognized the tie that architecture provides to the past, and they used architecture to authenticate modern construction by connecting it to historical pilgrimage sites.

American Catholics like P. J. Chandlery criticized those who "modernized" historic sites. In his pilgrimage account, Chandlery described the family mansion of St Cecilia converted into a church in 230, explaining that two cardinals "modernized" it in 1725, "robbing it of much of its ancient impressive character." 15 A bridge in Trastevere built by Pope Sixtus IV in the fifteenth century was "altered and spoilt" in $1870 .{ }^{16}$ Chandlery visited Santa Sabina on the Aventine in Rome, and in his account he outlined the history of the site. He decried Pope Sixtus V's "ill-

\footnotetext{
${ }^{12}$ Starr, Pilgrims and Shrines, 62.

13 “Switzerland's Holy Town," Sacred Heart, March 17, 1894.

${ }^{14}$ Chandlery, Pilgrim Walks in Rome, 258.

${ }^{15}$ Ibid., 321.

${ }^{16}$ Ibid., 335.
} 
advised alterations" in 1586 in which the church's ancient pavements and mosaics were destroyed. Fortunately, according to Chandlery, the church "retains most of its ancient features." 17 The ancient convent of Santa Maria Aventina had been "modernized and spoiled."18 Chandlery chronicled the history of the convent of St Caius, one that ended in the "time-honored buildings" being razed to the ground. He lamented that "respect at least for antiquity should have stayed the hand of the destroyer." 19 The authenticity that historic structures provided to a pilgrimage site was important to pilgrims of the period.

Throughout the centuries, the Catholic Church in Rome repurposed Roman temples and buildings into churches, resulting in the preservation of these structures. American Catholic pilgrims were aware of this fact and admired the ancient architecture. In her pilgrimage account writing about the Pantheon, Eliza Allen Starr noted that in 608 Pope Boniface IV converted the pagan temple into a church, "wishing to preserve this noble monument of ancient Rome by devoting it to the worship of the true God." ${ }^{20}$ Starr also described an arch of an ancient aqueduct preserved in the walls of the monastery of the Scala Sancta in Rome, explaining that it is "one more example of the manner in which the Church has preserved the traditions of pagan as well as of Christian Rome." She asserted that "as long as one monastery remains to shelter them, Rome will be preserved to future generations." ${ }^{21}$ The pilgrimage guide Pilgrim Walks in Rome contains a whole section on pagan monuments converted to Christian churches, listing fourteen of them including both the name of the church and its former use. ${ }^{22}$ The guide claimed "[the Church] preserved the ancient monuments of Rome. But for them the Coliseum, the Pantheon, and

\footnotetext{
${ }^{17}$ Chandlery, Pilgrim Walks in Rome, 289-290.

${ }^{18}$ Ibid., 297.

${ }^{19}$ Ibid., 261.

${ }^{20}$ Starr, Pilgrims and Shrines, 313.

${ }^{21}$ Ibid., 200.

${ }^{22}$ Chandlery, Pilgrim Walks in Rome, 187-188.
} 
Hadrian's Mausoleum, etc., might have long since disappeared." ${ }^{23}$ Another pilgrimage guide, $A$

Roman Pilgrimage, reviewed the Roman Forum stating

one of the most splendid records of Imperial Rome in the Forum is the Basilica Emilia, restored from the Republican building of Marcus Fulvius

Nobilior....Plautus mentions it in the Cucurlio.... and Livy speaks of it as something immemorial, part of the history of the city....carefully restored by the Rome that had ceased to worship there. ${ }^{24}$

The Catholic Church repurposed Roman structures into churches that became pilgrimage sites.

By doing so, the Church preserved the ancient monuments and pilgrims were interested in them as both pilgrimage destinations and sites of Roman history.

The historic structures that made up pilgrimage sites provided a physical connection to the historical Church. Ultimately, it was the location of pilgrimage sites that imbued them with a sacred quality, but the visual historicity of pilgrimage shrines offered pilgrims a tangible reminder that the site was linked to the past. The Basilica of Constantine in Rome, originally built in the fourth century, had to be rebuilt in the sixteenth century. A pilgrimage guide remarked "the modern basilica....can never adequately supply the place which the original sanctuary held in Catholic hearts, for it had been the central point of the Church's history for nearly twelve hundred years, and was a connecting link with the Church of the Catacombs." 25 The church of Saint Mary Major in Rome was “a monument of the love of [the Church's] children, not for one age only, but through all these glorious ages of Christianity." ${ }^{26}$ The remaining foundations of historic structures harked back to the Church of old. "The veritable foundations" of the Tower of St Benedict in Rome "of which, more than twenty feet thick, still exist as they were in his time" are a "genuine relic of the first age of the Benedictine

\footnotetext{
${ }^{23}$ Chandlery, Pilgrim Walks in Rome, 33-34.

${ }^{24}$ Roberts, A Roman Pilgrimage, 42.

${ }^{25}$ Chandlery, Pilgrim Walks in Rome, 10-11.

${ }^{26}$ Starr, Pilgrims and Shrines, 322.
} 
sanctuary." ${ }^{27}$ Pilgrim Eliza Allen Starr spoke directly to Americans about the importance of maintaining historic structures to preserve history. She wrote

To Americans, who have the same idea in locating a church that they have in placing a school-house or a town hall, viz.: the convenience of the parish, the sight of so many churches in a neighborhood absolutely uninhibited save by those who serve them, is sufficient to prove how carefully Christianity protects everything connected with her history, early or late. ${ }^{28}$

Pilgrims voiced their desire to preserve pilgrimage sites. Rev James Pfeiffer was a

participant in the first American Catholic pilgrimage to Palestine, and he published an account of his pilgrimage. In his introduction, Pfeiffer described the poor condition of the pilgrimage sites within Palestine. He wrote

If we would more fully realize this deplorable condition we would and ought to contribute more to the collection for the rescue of the Holy Places, which is ordered by our Rt Rev Bishops on Good Friday. It is this principally, that induced me to write this book. That Almighty God may move the minds and hearts of the reader, is the sincere wish of The Author. ${ }^{29}$

The main purpose of writing the book was to encourage readers to aid in the preservation of historic sites.

American Catholics actively engaged in the preservation of the past when they donated funds towards the care of pilgrimage sites. An article in The Catholic Telegraph announced that the famous pilgrimage shrine of Our Lady of Consolation in Carey, Ohio needed a renovated edifice at the cost of $\$ 250,000$. Subscriptions were requested "all over the United States." ${ }^{30}$ In 1890, The Sacred Heart Review encouraged pilgrims to the Holy Land to make offerings for the preservation of the holy sites. The article reminded readers, "this is, indeed a great and holy work, and it is one the importance of which increases year by year, and it is earnestly hoped that

\footnotetext{
${ }^{27}$ Starr, Pilgrims and Shrines, 128-129.

${ }^{28}$ Ibid., 51.

${ }^{29}$ Pfeiffer, First American Catholic Pilgrimage to Palestine, 1889, vi-vii.

30 "Another Costly Church," The Catholic Telegraph, October 31, 1901.
} 
it will attract more and more attention of Catholics everywhere and call forth their generous benefaction." ${ }^{31}$ The pamphlet for the 1897 American national pilgrimage stated its intentions to inspire the faithful "with devotion to those sacred places [in Palestine], which are the pride of the Church, and to aid in their rescue and preservation." 32 After recounting the site's history, a pamphlet for Mary's First Shrine in the Wilderness near Pittsburgh requested offerings for the shrine. It outlined the spiritual benefits one acquired through donation, starting at one dollar and going up to ten. ${ }^{33}$ American clergy members solicited donations from the faithful as well. Father Boniface, an American monk residing in the monastery of Monte Cassino in Italy, made a voyage to the United States to ask aid in preserving the historic structure. Benefactors gifting a dollar or more were promised to share in the benefits of daily mass offered at the monastery. ${ }^{34}$ By making donations towards the maintenance of pilgrimage sites, both pilgrims and Americans at home were partaking in historic preservation.

Additionally, pilgrims demonstrated the importance of preserving material culture through their intimate interaction with relics. Although museums and archives now realize the power artifacts hold in bringing historic figures to life, particularly those who left no written record behind, pilgrims have recognized this fact for centuries. It is precisely because of an object's connection to a historic person that it is preserved as a relic. A relic is some object, often body parts or clothing, remaining as a memorial of a departed saint. ${ }^{35}$ What distinguishes a relic from an artifact is the imbued sacred quality perceived by the faithful. Traditionally, pilgrims

\footnotetext{
${ }^{31}$ Sacred Heart, February 22, 1890.

32 American National Pilgrimage pamphlet, 1896.

${ }_{33}$ Andrew Arnold Lambing, Mary's First Shrine in the Wilderness (Pittsburgh: Myers, Shinkle \& Co, 1882), $18-21$.

${ }^{34}$ Starr, Pilgrims and Shrines, 130.

35 "Relic," New Advent Encyclopedia, accessed September 16, 2020, https://www.newadvent.org/cathen/12734a.htm. Analyzing how the bodies of sacred persons, considered relics in the Catholic tradition, interact with discussions regarding NAGPRA and the ethics surrounding dead bodies would be an interesting future line of inquiry, but in this work I will focus on traditional elements of material culture, such as clothing, tools, books, etc.
} 
paid devotion to relics they visited, and clergy members worked to preserve relics for future pilgrims. Speaking of a relic associated with Jesus, an article reminded readers that it was "a precious inheritance for the Christians of all future ages." ${ }^{36}$ In reference to an altar said to have been used by the apostle Peter, a pilgrim proclaimed, “Ah! But the wooden altar....is a link between the apostles and ourselves." 37

It was vital to the Church that future pilgrims had the opportunity to actively engage with relics, resulting in the preservation of material culture. Encountering relics was sometimes the reason for pilgrimage journeys. The material culture mentioned as relics in pilgrimage accounts of the period included clothing such as swaddling clothes, linen cloths, tunics, tilmas, coats, shoes, hats, veils, mantles, and robes. ${ }^{38}$ Accounts noted houseware including bowls, plates, stones, cabinets, lanterns, chairs, writing cases, and vases. ${ }^{39}$ Works of art were considered relics such as statues, tapestries, paintings, medallions, and busts. ${ }^{40}$ Accounts named religious articles as relics, listing prie-dieus, portable altars, crucifixes, chasubles, chapel doors, crosses, monstrances, and mitres. ${ }^{41}$ Other articles including pillars, columns, arrows, crowns, nails, wooden stairs, cribs, spurs, swords, letters, and writings were considered relics. ${ }^{42}$

\footnotetext{
36 “The Story of the Holy Coat of Treves," Sacred Heart, September 19, 1891.

${ }^{37}$ Starr, Pilgrims and Shrines, 267.

${ }^{38}$ Sacred Heart, August 24, 1895; “A Visit to Argenteuil," Sacred Heart, September 8, 1894; "Our Lady of Guadeloupe," Sacred Heart, August 24, 1889; "The Story of the Holy Coat of Treves," Sacred Heart, September 19, 1891; Starr, Pilgrims and Shrines, 243; Chandlery, Pilgrim Walks in Rome, 285; Sheehy, Notes on the IrishCanadian Pilgrimage and Addresses, 49.

${ }^{39}$ Stoddard, Two Celebrated Sanctuaries of the Madonna in Italy, 55; Vetromile, Travels in Europe, Egypt, Arabia Petrae, Palestine and Syria, 159, 163; Starr, Pilgrims and Shrines, 32, 159, 215; Chandlery, Pilgrim Walks in Rome, 22; Sheehy, Notes on the Irish-Canadian Pilgrimage and Addresses, 30.

${ }^{40}$ Stoddard, Two Celebrated Sanctuaries of the Madonna in Italy, 55; Vetromile, Travels in Europe, Egypt, Arabia Petrae, Palestine and Syria, 52; Chandlery, Pilgrim Walks in Rome, 21, 69; Sheehy, Notes on the Irish-Canadian Pilgrimage and Addresses, 30.

${ }^{41}$ Vetromile, Travels in Europe, Egypt, Arabia Petrae, Palestine and Syria, 52; Starr, Pilgrims and Shrines, 35, 243; Chandlery, Pilgrim Walks in Rome, 24, 226, 373; Pfeiffer, First American Catholic Pilgrimage to Palestine, $1889,236$.

${ }^{42}$ Sheehy, Notes on the Irish-Canadian Pilgrimage and Addresses, 30, 39-40, 58; Pfeiffer, First American Catholic Pilgrimage to Palestine, 1889, 43, 116.
} 
Those maintaining pilgrimage sites wanted to keep relics in good condition. The Holy Coat in Treves, Germany, a coat said to have belonged to Jesus, was rarely displayed for the public. In 1891, when it was to be exposed, the coat was not found to be in a condition suitable for exhibition. The local Bishop "consulted experts" and determined that fragments of the garment had to be "gummied" together because the material was too worn "to stand the strain of needle and thread."43 The stone of unction, where Jesus's body was allegedly anointed after his death, is held in the Church of the Holy Sepulchre in Jerusalem. Those managing the site found it necessary to cover the stone with a slab of marble and surround it with iron railing. ${ }^{44}$ This was done to deter pilgrims from breaking pieces off the stone or trying to step on it. In a basilica in Milan, pilgrims had the opportunity to pray before a nail believed to be from Jesus's cross. Clergymen fastened the nail to the ceiling of the basilica, due to their concern for pilgrims damaging or stealing it in their devotion. ${ }^{45}$

The faithful preserved objects of material culture because they hoped to use them to encourage pilgrimage. The exposition of holy relics at Aix-la-Chapelle, France in 1895 attracted ten thousand pilgrims. ${ }^{46}$ The sacred tunic allegedly worn by Jesus, held in Argenteuil, France resulted in one hundred and fifty thousand pilgrims visiting the relic in one month. ${ }^{47}$ The chapel of the Santa Sindone in Turin, Italy became a destination of pilgrimage due to its possession of the burial shroud, believed to have bound Jesus. ${ }^{48}$ When visiting the Tomb of the Apostles in Rome, a pilgrim remarked "it had not been so much a visit to the Tomb of the Apostles, as a visit to their precious and holy relics." 49

\footnotetext{
43 "The Story of the Holy Coat of Treves," Sacred Heart, September 19, 1891.

${ }^{44}$ Vetromile, Travels in Europe, Egypt, Arabia Petrae, Palestine and Syria, 159.

${ }^{45}$ Pfeiffer, First American Catholic Pilgrimage to Palestine, 1889, 236.

46 Sacred Heart, August 24, 1895.

47 “A Visit to Argenteuil," Sacred Heart, September 8, 1894.

${ }^{48}$ Vetromile, Travels in Europe, Egypt, Arabia Petrae, Palestine and Syria, 208.

${ }^{49}$ Star, Pilgrims and Shrines, 71.
} 
Relics found at pilgrimage sites linked pilgrims to historical eras, allowing them to imagine how daily life was for a certain saint. Some pilgrimage sites housed a single relic, while other sites amassed hundreds of relics and artifacts, forming their own collections. ${ }^{50}$ These physical objects allowed pilgrimage sites to connect themselves to historic sacred figures and eras of the past. Those managing pilgrimage sites understood the power material culture can possess, and by preserving relics, used this power to attract pilgrims to their sites. The preservation of relics is not only essential for Catholic pilgrims due to sacred associations but should also be recognized as significant by the public at large. For the Church preserved objects that would have otherwise been destroyed, and these artifacts can shed light on the past.

Aside from ancient pilgrimage sites, newspaper articles and pilgrimage accounts reveal that American Catholics were visiting newly established sites as well. In fact, lay people and clergy members were creating new pilgrimage sites at the turn of the twentieth century. In founding pilgrimage destinations, the faithful memorialized sacred events using structures and objects. They constructed tangible heritage and furnished caretakers to maintain and preserve holy places for future generations. Grassroot movements shaped some sites at the local level, while others were forged by clergymen who wished to inspire local pilgrims.

The most popular modern pilgrimage site was the shrine of Our Lady of Lourdes in France, formed by local lay people. Soon after Bernadette, a poor French girl, began having visions of the Virgin Mary in 1858, pilgrims visited the sacred grotto where the alleged apparitions took place. Workmen from Lourdes realized that the ground surrounding the grotto was muddy due to a newly-formed miraculous spring. They dug a channel for the water and

\footnotetext{
${ }^{50}$ An example is the collection held at Notre Dame Cathedral in Paris that contained artifacts such as the mantle worn by Napoleon I at his coronation and vestments exhibited at the Paris Exposition of 1867, as well as many sacred relics. (Sheehy, Notes on the Irish-Canadian Pilgrimage and Addresses, 39-40).
} 
hollowed out a deep basin under the Grotto, connecting the water by a wooden pipe. They also constructed a path up the steepest ascent to the grotto, enabling pilgrims to approach more easily. ${ }^{51}$ Pilgrims began decorating the grotto with moss, flowers, and candles. A crude altar was set up in the cave, topped with a statue of the Virgin Mary. Many pilgrims left offerings of money for a chapel "which they desired to be built on the spot." 52 The water from the miraculous spring reportedly resulted in cures for various illnesses and physical maladies. Pilgrims appealed to ecclesiastical authority for its seal of approval for the pilgrimage site. An ecclesiastical commission worked for four years, collecting evidence to determine the authenticity of the apparition. In January of 1862 , the Church endorsed the pilgrimage site. ${ }^{53}$ Lourdes developed from a grassroots pilgrimage site visited by the local faithful to a pilgrimage site endorsed by the wider Church and visited by pilgrims across the globe.

The creation of Our Lady of Martyrs shrine in Auriesville, New York came about less organically, as it was a project developed by a clergy member. In 1884, Rev Joseph Loyzance purchased a tract of land determined to be the site of death for Jesuit missionaries St Father Isaac Jogues and St Father René Goupil. ${ }^{54}$ Clergy members used contemporary maps, letters, accounts, and topography as evidence for the authenticity of the selected location. ${ }^{55}$ Rev Loyzance wished to make the spot "sacred to the memory of Fathers Jogues and Goupil." 56 As the locale was not already a site of local pilgrimage, Rev Loyzance had to market the shrine to attract pilgrims. Rev Loyzance developed The Pilgrim of Our Lady of Martyrs, a magazine dedicated to sharing the history of the shrine. ${ }^{57}$ In 1885 , Rev Loyzance erected the chapel of Our Lady of Martyrs in

\footnotetext{
${ }^{51}$ Francis, Little Pilgrims to Our Lady of Lourdes, 94-95.

52 Ibid., 127.

${ }^{53}$ Ibid., 160.

${ }^{54}$ A Pilgrimage to the Shrine of Our Lady of Martyrs: Auriesville, NY, 1890, 31.

55 Ibid., 28.

56 “Catholics on a Pilgrimage," New York Times, August 17, 1891.

${ }^{57}$ A Pilgrimage to the Shrine of Our Lady of Martyrs: Auriesville, NY, 1890, 31.
} 
conjunction with the publication of Life of Isaac Jogues by Dr John Gilmary Shea. ${ }^{58}$ By 1890 , the site attracted pilgrims from as far away as Amsterdam. Rev Loyzance erected an open chapel to shelter pilgrims during mass in 1894, and a year later the site had its own sanctuary, sacristy, dwelling rooms, and an extra sixteen acres. ${ }^{59}$ In 1896 for the two-hundred-and-fiftieth anniversary of the death of Father Jogues, Rev Loyzance produced a shrine manual, issued a shrine medal, and developed an exhibition on Jogues with the help of Rev A. E. Jones, an archivist from Montreal. ${ }^{60}$

The shrine published a pamphlet in 1902, in which it outlined the regulations it had established for pilgrimages, "conducive to the order and piety of the pilgrims." 61 The pamphlet suggested that pastors announce their pilgrimage to the shrine as soon as possible, "giving date of pilgrimage, time of departure and return, and the Order of the Exercises at the Shrine." ${ }^{62}$ It advised pastors to give instruction on the purpose of pilgrimage in their churches sometime before, so that "the mere pleasure seekers will remain at home, and the pilgrims will be better disposed to reap the full benefit of their piety." ${ }^{63}$ A pilgrimage committee was to be chosen from the parish, to help the priest conduct the pilgrims to and from the railway stations, lead devotions, aid in mass and processions. Pilgrimage groups were to also bring their own choir that should be "as large as possible" for singing on the way to the shrine, in the procession, during mass, and other devotions. The pamphlet requested pilgrimage groups to carry banners and flags

\footnotetext{
${ }^{58}$ A Pilgrimage to the Shrine of Our Lady of Martyrs: Auriesville, NY, 1890, 31.

${ }^{59}$ In the month of August four thousand pilgrims from the surrounding area went on pilgrimage to the shrine. In 1890, Ellen H. Walworth published Life and Times of Kateri Tegakwita, giving visibility to the shrine. Ibid.

${ }^{60}$ The anniversary spurred Rev Loyzance to build a grotto in a nearby ravine and a way of the cross on the shrine's grounds. The Way of the Cross is a Catholic devotional practice in which the faithful reflect on Jesus's path to his crucifixion. Pilgrimages were numerous that year, a single pilgrimage bringing five thousand persons. By 1901, the shrine had its own hotel and an additional four acres. (Ibid., 32.)

${ }^{61}$ Ibid., 63.

${ }^{62}$ Ibid.

${ }^{63}$ Ibid.
} 
and to wear pins in order to identify their community. It included a train schedule and advice on where to eat lunch and buy souvenirs. ${ }^{64}$

The shrine of Our Lady of Martyrs was funded through donations made by benefactors.

The 1902 pamphlet stated

since the first purchase of land at Auriesville, in 1884, not a year has passed without some improvement in or about the grounds. These improvements, together with the expense connected with the attendance on the pilgrims, especially when they come in large numbers, have all cost large sums of money, considering our limited resources, and yet, thank God, they have all been paid for by the charity of the friends and patrons of the cause of the Martyrs. Although, in all justice, we might have called upon the pastors and other leading parties to visit the Shrine to help us meet these expenses, we have never asked nor received an offering from them. What is more, we have never required admission tickets at the Shrine grounds, nor charged for entrance, nor even sought to obtain a commission from the railroad and other transport companies bringing pilgrims to Auriesville. We do not mention this by way of boasting of our generosity, for we are aware that most people will attribute it to poor business methods, while others will malevolently regard the pilgrimages as a scheme for making money. ${ }^{65}$

As much as Rev Loyzance desired to set the site apart as a pious venture, the creation of

the shrine mirrors the development of a secular historic site. Just as secular organizers attempt to make the public care about an historic event to attract visitors to their site, Rev Loyzance published and distributed a magazine outlining the history of the sacred site to local Catholics. Rev Loyzance also endeavored to cultivate interest in the historic figures associated with the shrine, coordinating the publication of their biographies. As pilgrims became more numerous, the shrine had to grow and develop to meet their needs, through new construction and the purchase of more land. Historic sites face the same dilemma as they become more popular. Rev Loyzance took advantage of the anniversary of Father Jogues's death to promote the shrine and increase its visibility, much like any public history organization. By coordinating pilgrimage

\footnotetext{
${ }^{64}$ A Pilgrimage to the Shrine of Our Lady of Martyrs: Auriesville, NY, 1890, 63.

${ }^{65}$ Ibid., 50. Italics preserved from the source.
} 
groups and setting regulations, Our Lady of Martyrs shrine created the same kind of infrastructure found at tourist destinations. Both shrine directors and historic site directors hope their site is efficiently run and well-organized, in order to provide pilgrims or tourists with the best, authentic experience. By doing so, news of the site will spread, bringing even more visitors. Our Lady of Martyrs shrine appeared to have been a successful enterprise by the early twentieth century, with its number of pilgrims increasing every year. ${ }^{66}$

Those founding shrines in the US attempted to cultivate a history of pilgrimage within the country, connecting their site to that tradition. At the turn of the twentieth century, shrines sprung up all around the United States in places like Illinois, Washington DC, and Wisconsin. ${ }^{67}$ St Anne shrine in Isle La Motte, Vermont, claimed to have "one of the earliest chapels erected in this country.... the very first constructed in Vermont, and the first also in the United States to be dedicated to St Anne." ${ }^{\circ 8}$ A pilgrimage chapel was erected in Robinsonville, Wisconsin, and clergymen maintaining the site published a pamphlet describing the many pilgrims that had historically visited the locale. ${ }^{69}$ Shrines in the United States were competing against the very popular European shrines for visibility, and their emphasis on marking the sites as both American and Catholic was a technique used to attract American Catholic pilgrims. New pilgrimage sites cropping up outside the US did not highlight a particular national

\footnotetext{
${ }^{66}$ A Pilgrimage to the Shrine of Our Lady of Martyrs: Auriesville, NY, 1890, 32.

${ }^{67}$ A community in Kankakee, Illinois founded a shrine to facilitate the veneration of a relic brought back from Rome in 1888 ("Illinois Pilgrimage," The Catholic Telegraph, August 7, 1902). The National Organization of Catholic Women of the United States of America raised funds for the National Shrine of Mary Immaculate, to be built in Washington DC (Church to be Erected as a National Shrine in Honor of Mary Immaculate, 1914, DC 80, Printed Ephemera, The Catholic University of America, The American Catholic History Research Center and University Archives, Washington, DC). In 1899, the Church established the Franciscan Monastery of Mount St Sepulchre known as the "Holy Land in America" (Hillary Kaell, Walking Where Jesus Walked: American Christians and Holy Land Pilgrimage (New York: New York University Press, 2014)).Polish Catholics wanted to erect a pilgrimage shrine for Father Marquette in Wisconsin (Sacred Heart, October 28, 1893).

68 "A New England Shrine," Sacred Heart, July 16, 1898.

69 'I am the Queen of Heaven.' The Story of 'the Chapel,' at Robinsonville, 1910, W1 188, Printed Ephemera, The Catholic University of America, The American Catholic History Research Center and University Archives, Washington, DC, 17-18.
} 
allegiance. A newspaper article from February 19, 1898 reported that the Friars Preachers, a religious order, purchased the old house of St Dominic, their founder, in Fanjeaux, France. The friars hoped to restore the building and "no doubt the crowds of pilgrimages to the monastery....after venerating the Virgin of the Rosary at Proville, will come to show their gratitude."70 The friars wanted to put the stone dwelling on the map of already existing pilgrimage routes. They attempted to initiate pilgrimage through the restoration and beautification of a medieval village. These are the same techniques secular governments or foundations used to transform a historic building into a touristic site. Pilgrimage sites were not always destinations that naturally gained popularity, but rather the faithful, at times, reconstructed or unearthed lost histories to put sites within view, much like locales cultivating their touristic potential.

Museums became common stops on pilgrimage itineraries. A young Catholic layman founded a Eucharistic museum in Paray-le-Monial, France. ${ }^{71}$ The shrine of Our Lady of Hermits in Switzerland contained a museum within the adjoining Benedictine Abbey. ${ }^{72}$ In Avignon, France in 1895 , the mayor proposed to transform the palace of the Popes into a museum of Christianity. An article reported that the changes could cost six million francs. It stated, "it is hoped when the museum is opened to the public, that it will become an attractive resort for European pilgrims, and by bringing thousands of strangers to the city will form a new source of revenue for the local industries and commerce." ${ }^{, 73}$ In this case, a secular figure spearheaded a project that created a religious museum whose targeted audience was pilgrims.

When on pilgrimage, some pilgrims were interested in admiring libraries and manuscript

\footnotetext{
${ }^{70}$ Sacred Heart, February 19, 1898.

71 Sacred Heart, April 4, 1891.

72 Pfeiffer, First American Catholic Pilgrimage to Palestine, 1889, 247.

${ }^{73}$ Sacred Heart, November 16, 1895.
} 
collections, as the ancient documents connected them to Catholic history, sacred figures, and pilgrims who came before. Clergymen and religious orders preserved books and documents for their own study, as well as that of pilgrims. Seminaries and monasteries formed their own archival collections, transforming the men who cared for the texts into archivists. ${ }^{74}$ A pilgrim to the shrine of Our Lady of the Hermits in Switzerland remarked that the Benedictine monks there had a library "rich in precious and unique manuscripts, and their archives contain treasures of ecclesiastical and archeological lore." 75 In reference to the manuscript collection at a monastery in Italy, a pilgrim proclaimed "let us dwell a moment on the antiquity of these treasures, for these archives, of which not only Monte Cassino but the whole world of letters is proud....[have] existed more than thirteen hundred years."76 The archives were open every day to the visitor or scholar, cared for by a "first and second Archivist, and to these are given two assistants." The closets and drawers housing the documents were lined with cypress wood "to insure the safety of the parchments." 77 The monastery of Monte Cassino also had a library that contained a codex printed by "one of the three inventors of printing," as well as a copy of the New Testament dating from the fifteenth century. The historic tomes were kept "under glass, protected from the rays of the sun by curtains of green silk."78

Additionally, pilgrimage sites kept documents relating to their authentication, history, and operations, fashioning their own small archival collections. St Anthony's shrine in Ohio kept

\footnotetext{
${ }^{74}$ A seminary in Treves, Germany close to the Cathedral contained a library of over nine thousand volumes and numerous manuscripts, including the famous "Codex Aureus." The "Codex Aureus" is a manuscript of the Gospels written in gold letters. ("Switzerland's Holy Town," Sacred Heart, March 17, 1894). The Vatican library, founded in 1378 and containing over one hundred thousand volumes and twenty-five thousand manuscripts, preserved manuscripts written by St Thomas Aquinas, Dante, and Petrarch (Pfeiffer, First American Catholic Pilgrimage to Palestine, 1889, 41; Chandlery, Pilgrim Walks in Rome, 40).

75 "Switzerland's Holy Town," Sacred Heart, March 17, 1894.

${ }^{76}$ Starr, Pilgrims and Shrines, 126.

${ }^{77}$ Ibid.

${ }^{78}$ Ibid., 123.
} 
a record of the names of pilgrims to the shrine, "which will be of no little interest for generations to come." 79 To authenticate miracles taken place at the shrine of Our Lady of Good Counsel in Genazzano, Italy, a religious order appointed a notary public to examine each case. The notary was instructed to keep "a record of them for future times" and the record is "still preserved in the archive of the convent." 80 Additionally, a report was drawn up with the testimony of seven witnesses to a miracle and submitted to an ecclesiastical council. The "original of this document" was "preserved" at the church of Genazzano, a site of pilgrimage. ${ }^{81}$ The archives of Monte Cassino preserved the documents declaring the consecration of the church on site, with the twelve seals of the twelve bishops present at the occasion. ${ }^{82}$ Pilgrimage sites preserve historic structures, material culture, and institutional archives.

The desire to rediscover lost sacred spaces at the turn of the twentieth century resulted in an explosion of archaeological projects sponsored by the institutional hierarchy. Cathedrals, churches, and monasteries were the site of early excavations. ${ }^{83}$ Catholic archaeological projects centered in both Rome and Jerusalem, but Roman excavations were more popular. By 1852, the Church established the Commission for Sacred Archaeology due to recent discoveries of the catacombs in Rome. ${ }^{84}$ Through these efforts, modern Christian archaeology was born, established on a scientific basis. ${ }^{85}$ News of archaeological finds found its way in newspaper articles and pilgrimage accounts, inducing pilgrims to add these sites to their pilgrimage

\footnotetext{
79 "Pilgrimage to St Anthony's Shrine," The Catholic Telegraph, May 4, 1893.

${ }^{80}$ Stoddard, Two Celebrated Sanctuaries of the Madonna in Italy, 16.

${ }^{81}$ Ibid., 15.

${ }^{82}$ Star, Pilgrims and Shrines, 126.

${ }^{83}$ Christopher Gerrard, "The medieval revival: Romanticism, archaeology and architecture" in Nineteenth-Century European Pilgrimage: A New Golden Age, edited by Antón M. Pazos (New York and London: Routledge, 2020), 32.

${ }^{84}$ Ibid., 35.

${ }^{85}$ Massimiliano Ghilardi, "The Roman catacombs in the nineteenth century: 'Cradle and Archive of the Catholic Church"” in Nineteenth-Century European Pilgrimage: A New Golden Age, edited by Antón M. Pazos (New York and London: Routledge, 2020), 53.
} 
itineraries.

The Sacred Heart Review published an article in 1896 on the ruins of a great basilica in Jerusalem, brought to light through excavation. The foundation, naves, atrium, and the whole ground floor of the basilica were visible, and the authenticity of the remains, mosaics, and inscriptions were verified by "well known archaeologists." The author noted that "pilgrims and tourists to Palestine delight to visit these ruins, the best preserved of any in Jerusalem, which excite the liveliest interest among archaeologists as well as among devout Catholics." 86 "Most interesting to archaeologists, as well as to students of church history," another article began, were the excavations of the Church of St Cecilia in Rome. ${ }^{87}$ There, archaeologists exposed the remnants of an ancient Roman house, where the "tessellated pavement" was "well preserved" in some of the rooms as well as fragments of sculpture. ${ }^{88}$ These ruins guaranteed that "few visitors to Rome will henceforth fail to make a reverential pilgrimage to the honored Church of Cecilia." ${ }^{89}$ Excavations took place at the Dominican convent of San Clemente in Rome, where a subterranean church and frescos dating to the fifth century were recovered from below the earth. The church was found "in almost perfect preservation." 90 Excavations around the church of St Saba in Rome in 1900 unveiled the apse and walls of an oratory dating from the seventh century. The discovery "adds greatly to the religious attractions of St Saba, and pilgrims delight to linger in its ancient church and secluded cloisters." 91

Archaeologists discovered many sections of the catacombs in the nineteenth century. In 1854, archaeologists stumbled upon the crypt of the Popes, one of the most sacred places of the

\footnotetext{
86 Sacred Heart, January 25, 1896.

87 "Church of St Cecilia," The Catholic Telegraph, April 12, 1900.

${ }^{88}$ Chandlery, Pilgrim Walks in Rome, 326.

89 "Church of St Cecilia," The Catholic Telegraph, April 12, 1900.

90 “An Art Pilgrimage Through Rome," The Catholic World, September 1873.

${ }^{91}$ Chandlery, Pilgrim Walks in Rome, 302.
} 
early Christian Church. ${ }^{92}$ Excavations revealed a new gallery with a high altar, some brickwork tombs from the fourth and fifth centuries, and the silver coffin protecting the bodies of St Agnes and St Emerentiana. ${ }^{93}$ These discoveries placed the Roman catacombs on the map, resulting in a flood of pilgrims who desired to pray in the sacred spaces of the early Church. ${ }^{94}$

Sometimes archaeological finds were used as a way to revive pilgrimage sites. In 1879 , archaeologists uncovered human remains in the Santiago Cathedral in Spain. The find was a result of an intentional search. ${ }^{95}$ The Pope confirmed them to be the remains of the apostle St James. Clergy members constructed a new crypt for the remains and published the discovery in guidebooks, hoping to connect the cathedral to the increased pilgrimage movement to Rome, Lourdes, and other destinations. ${ }^{96}$ In Canterbury, England, archaeologists searched for the remains of an ancient altar, crypts, and relics in St Augustine's abbey. The archeological site became a leading center of pilgrimage due to its sacred associations. ${ }^{97}$

Catholics used their archaeological discoveries to better understand the past. This is most evident in a pilgrim's account of Rome. She explained that the city could not forget its history for "buried, its history still lives; and the pick-axe of the excavator is the guarantee of its faithful historians." 98 The excavations at the Church of St Cecilia in Rome revealed an ancient Roman house in which "the remains of a fine bath-room — of a great hall in the form of a basilica — of a niche for the ancient household gods, and various other details are still plainly visible." 99 The

\footnotetext{
92 Ghilardi, "The Roman catacombs in the nineteenth century," 54.

93 Tablet, December 21, 1901.

94 Ghilardi, "The Roman catacombs in the nineteenth century," 54.

95 Antón M. Pazos, "Compostela, Rome and the revival of the pilgrimages to Santiago" in Nineteenth-Century European Pilgrimage: A New Golden Age, edited by Antón M. Pazos (New York and London: Routledge, 2020), 102.

96 Ibid., 101.

${ }^{97}$ Isaac Sastre de Diego, "Sacred archaeology in nineteenth-century England" in Nineteenth-Century European Pilgrimage: A New Golden Age, edited by Antón M. Pazos (New York and London: Routledge, 2020), 140.

${ }^{98}$ Starr, Pilgrims and Shrines, 144.

99 "Church of St Cecilia," The Catholic Telegraph, April 12, 1900.
} 
finding allowed archaeologists and scholars to better understand how Roman homes were structured and constructed. The finding also confirmed "the ancient and honored tradition that the present basilica was erected above the site of the house of St Valerian, the husband of St Cecilia." 100 Archaeologists found a sepulchral inscription recording the burial place of a sixthcentury abbess, the head of a convent, in a Roman neighborhood. With this new evidence, scholars concluded that "a regular convent of nuns, with a superior, existed here at that early date." 101 The excavations of the catacombs opened "a new branch of research peculiar to Rome" in which early Christian symbolism was studied so that early Church history could be better understood. ${ }^{102}$

To ensure that Catholics across Europe had access to the archaeological discoveries from the catacombs, even if they were unable to make a pilgrimage to Rome, clergy members from the Vatican created full-scale models of the catacombs made of wood, cork bark, terracotta slabs, and plaster to be sent to various destinations. The 1867 Universal Exhibition in Paris displayed a facsimile of the catacombs that was unexpectedly popular. ${ }^{103}$ In 1909 , the Pontifical Commission for Sacred Archaeology authorized the construction of a replica in the Netherlands. In exchange, those reproducing the catacombs donated large sums to finance the excavation and restoration work undertaken in the Roman catacombs. ${ }^{104}$ Vatican officials traveled to the Netherlands on several occasions to "verify the accuracy of the reproduction of original Roman paintings." The replica quickly became both a popular pilgrimage destination and a center for Christian archaeological studies, attracting seven thousand visitors in the first year alone. ${ }^{105}$

\footnotetext{
100 "Church of St Cecilia," The Catholic Telegraph, April 12, 1900.

${ }^{101}$ Chandlery, Pilgrim Walks in Rome, 273.

102 “An Art Pilgrimage Through Rome,” The Catholic World, September 1873.

${ }^{103}$ Ghilardi, "The Roman catacombs in the nineteenth century," 55.

104 The replica was made out of rock and is still a tourist destination today (Ibid., 56).

105 Ibid.
} 
Those who were fortunate enough to visit the catacombs in Rome experienced the site through the interpretation of guides. Members of the clergy or religious orders often acted as guides, a fact confirmed by the stereotypical friar guide formed in travel literature of the period. ${ }^{106}$ Torchlit tours of the catacombs became a popular activity for pilgrims and tourists alike. ${ }^{107}$ According to a pilgrim, an excellent guide was one "who left one to one's own reflections, while he was careful to show us everything, and to explain all that needed explaining." 108 Another pilgrim delighted in the fact that the Rector of the American College was their guide, as he would "point out everything to us, and explain everything to us as if we were all children. You can ask as many questions as you please." Through the rector's interpretation "they would really learn all about the catacombs, which had been one of their dreams on coming to Rome." 109 Some guides even allowed pilgrims to touch the relics of martyrs resting in the catacombs, an experience they thoroughly enjoyed. ${ }^{110}$ When experiencing archaeological sites, pilgrims expected a guide to interpret the ruins, providing historical and theological context. Guides were frequently mentioned by pilgrims in their accounts, as they visited sacred spaces. ${ }^{111}$ At the church of Santa Maria in Trastevere, a pilgrim explained to her guide that "if I

\footnotetext{
106 Ghilardi, "The Roman catacombs in the nineteenth century," 51.

${ }^{107}$ Stephen L. Dyson, "The Grand Tour and after: Secular pilgrimage to Rome from the eighteenth to the twentieth centuries" in Nineteenth-Century European Pilgrimage: A New Golden Age, edited by Antón M. Pazos (New York and London: Routledge, 2020), 93; Sheehy, Notes on the Irish-Canadian Pilgrimage and Addresses, 59; Chandlery, Pilgrim Walks in Rome, 240.

108 Roberts, A Roman Pilgrimage, 81-82.

${ }^{109}$ Starr, Pilgrims and Shrines, 79-80.

${ }^{110}$ Ghilardi, "The Roman catacombs in the nineteenth century," 52.

${ }^{111}$ At the church in Italy where St Francis is buried, Franciscan fathers led pilgrims around the church pointing out its three naves, "one of which the Italian government secularized....for a museum." (Pfeiffer, First American Catholic Pilgrimage to Palestine, 1889, 23). Clergy members guided pilgrims as they visited the holy sites in Paris and in Siena, where a guide interpreted the former home of St Catherine of Siena (Sacred Heart, October 12, 1895; Starr, Pilgrims and Shrines, 214). Pilgrims participated in guided tours at St Peter on the Golden Mount in Rome, John's oratory in Rome, and the cathedral of Rouen (Starr, Pilgrims and Shrines, 146; Chandlery, Pilgrim Walks in Rome, 8-9; Sheehy, Notes on the Irish-Canadian Pilgrimage and Addresses, 34). Another pilgrimage party had a guide with them throughout their pilgrimage in Rome, visiting St Peter's Basilica, the Coliseum, and the church of St Gregory the Great (Sheehy, Notes on the Irish-Canadian Pilgrimage and Addresses, 58).
} 
could have some living, actual person tell me about these places, I should feel so much more

confidence than when I am reading from a guide-book!" 112 A description of a tour of Santa

Pressede basilica in Rome, guided by a priest, sheds light on how sites were interpreted.

"We will merely glance into these chapels, beautiful as they are, with their choice altar pictures; for you can study these out at your leisure on future visits. Today your mind should take in, at one view, the characteristics of Santa Prassede herself, of the honor paid to her by the Church, and the principal works of art which draw to her shrine the lovers of the beautiful, even when they care nothing for the saint. Straight before you, almost at the end of the nave, you see what looks-"

"Like the curb of a well!" exclaimed Laura; "and now I see the head of a woman; and I should say there is a lamp in the well."

"Which there is: It was in this well that Santa Prassede hid the relics of the martyrs whom she could not screen from the rage of the persecutors. If you remember the story of Santa Prassede, you will remember that besides a sister, Pudenziana, she had two brothers, Novatus and Timotheus, also saints. These brothers owned the house which stood on this very spot, known as the baths of Novatus. This became the property of Santa Prassede, who seems to have outlived all her family. The house once in her possession, it became a refuge for those Christians who were hunted down by the cruel prefects... This heroic woman not only endangered her own safety by thus receiving them to her house, but she visited the prison, kissed the chains of the martyrs, accompanied them to the place of torture and of death, and then found ways to secure their precious relics, or their blood soaked up on sponges. The relics were concealed in this well until they could be deposited in the catacombs; and here you see a statue of Santa Prassede, wringing out a cloth or sponge, wet with the fresh blood of a martyr. The well is an almost invariable feature of these old Roman palaces turned into churches. You remember the one in Santa Pudenziana, and you will find one in the house of Sant' Alessio, now a church."113

Pilgrim guides interpreted art and architecture of sacred sites. They encouraged pilgrims

to relate what they were observing at the holy locale with the lives of historic figures and historic events. Guides also asked pilgrims to connect sites to destinations previously visited on their pilgrimage. Pilgrims learned about the history, art, and architecture of sacred spaces through the interpretation provided by tour guides, much like at secular historic sites.

\footnotetext{
112 Starr, Pilgrims and Shrines, 114-115.

113 Ibid., 283-284.
} 
Pilgrims did not always need a guide to interpret a pilgrimage site for them, as they engaged in what could be described as self-guided tours, interpreting the locale through its artwork. The faithful who decorated sacred places intended for their artwork to be "read" by pilgrims. Art within pilgrimage destinations displayed biblical history, the lives of saints, or the history of the site. A newspaper article explained that art displayed "all that it was useful for man to know - the dogmas of religious, the examples of the Saints, the hierarchy of the virtues, and the variety of the science, the arts and trades, were taught to him by the stained glass windows of the Church or by the statues of the porch." 114 Through a collection of frescos, a pilgrim "learned the lesson taught in the Rotunda of Saint Stephen" and Roman parents brought their children "to learn the history of the church and the story of her saints and martyrs. The great picture-book of the first ages of the Church." 115 The artwork in the Basilica Julia in the Roman Forum illustrated the history of the early Church, including how the Christians were martyred during the period. A guidebook extensively described the fresco for pilgrims, outlining what the scenes represented. ${ }^{116}$

Analyzing pilgrim accounts, it is obvious that pilgrims understood that they were to read and interpret the art decorating pilgrimage sites. A pilgrim described a site's art as "pictorial records of the cathedral history."117 The same pilgrim recorded that

Again and again we were made to realize, that these pictures were not painted merely to adorn the walls, but, rather, to adorn the souls of those who worshipped before these altars.... and to furnish their imaginations with the lovely imagery which the Church, through her gospels, epistles and traditions, have preserved for

\footnotetext{
114 “Saint Francis Day Devoutly Observed in Assisi," Sacred Heart, November 10, 1917.

115 Starr, Pilgrims and Shrines, 138-139.

${ }^{116}$ Chandlery, Pilgrim Walks in Rome, 183-184. Other examples include a chapel in Lourdes containing stainedglass windows representing the alleged apparition, the Cathedral of the Immaculate Conception in Albany displaying stained-glass "representing in radiant imagery more than tomes of sacred history," and murals in the catacombs depicted the story of the third Pope St Clement ("Catholic Thoughts and Events in Foreign Lands," Sacred Heart, January 16, 1897; Souvenir of the Golden Jubilee and Solemn Consecration of the Cathedral of the Immaculate Conception, 1902, 14-15; Starr, Pilgrims and Shrines, 169-171).

117 Starr, Pilgrims and Shrines, 179.
} 
the faithful, and which she is ever mindful to put before their eyes in ways which will attract their attention... ${ }^{118}$

Another pilgrim explained that "until the divorce between religion and art....it had not occurred to anyone that art should not be didactic; indeed the old masters were too wise to imagine that it could be anything else." ${ }^{119}$ Pilgrimage guides and accounts included extensive descriptions of art at pilgrimage sites and its represented histories. Pilgrims were trained to interpret sacred sites for themselves, through visual culture.

As much as pilgrims interpreted pilgrimage sites by way of guides and artwork, American Catholics were not always convinced by the veracity or authenticity of these spaces. On pilgrimage to St Anne de Beaupré in Canada, a pilgrim noted that "the visitor to Sainte Anne de Beaupré who goes there to observe is faced with a serious difficulty at the very outset. There is so much of tradition and hearsay mingled with the historical that it is almost impossible to unravel the one from the other." ${ }^{120}$ In a pilgrimage account, an author asserted that "I have no patience with relics frankly false, of which there are far too many, and none with feigned miracles." 121 Pilgrims questioned the traditions associated with certain pilgrimage sites. While visiting the Church of Santa Pudenziana in Rome, a pilgrim asked her companion if she really believed that St Peter said mass in the locale. The same pilgrim wondered how the Church could be so certain of the spot where an ancient house stood. ${ }^{122}$ Another pilgrim was not convinced that the room under the Church of Santi Giovanni e Paolo was the dining room that once belonged to St John and Paul, due to the iconography of the frescoes decorating the room. ${ }^{123}$ Their guide also

\footnotetext{
118 Starr, Pilgrims and Shrines, 181-182.

119 Roberts, A Roman Pilgrimage, 29.

${ }^{120}$ E. C. E. Dorion, "Pilgrimage to Sainte Anne de Beaupre: Mother of the Virgin Mary," Zion's Herald, August 25, 1909.

${ }^{121}$ Ibid., 143.

122 Starr, Pilgrims and Shrines, 264-265.

${ }^{123}$ Roberts, A Roman Pilgrimage, 68-69.
} 
showed them human remains venerated as the body of St Paul the apostle. The pilgrim doubted their authenticity, and he was able to confirm his suspicions, proving that the body belonged to St Paul of the Cross from the eighteenth century. ${ }^{124}$ The author of a pilgrimage account described his thoughts on the Scala Santa, the stairs said to have been taken from Jerusalem and placed in Rome and allegedly the stairs Jesus climbed on his way to his trial.

This relic is one that causes a good deal of heart-burning to the historian. For myself I do not think there is any reasonable doubt that the steps were never nearer Pilate's palace than they are now; and I would suggest that when the devotion began, probably at the times of the Crusades, no one thought they were the original stairs up which Our Lord went. ${ }^{125}$

American Catholics pilgrims cared about historical evidence and accuracy when visiting pilgrimage sites. One pilgrim read not only English guidebooks but French and Italian guidebooks to prepare for her pilgrimage. She studied the work of Edouard de Bleser on Rome and its Monuments, the lives of the Saints "not only by one author but by every one she could lay hold of," and the proclamations made by the Church on the saints in the Roman breviary. By doing so, "she could understand what were considered, by historians and antiquarians, as the genuine claims of each church to veneration. Her belief in these claims was an intelligent belief, not simple credulity." ${ }^{126}$ Another pilgrim was frustrated with the analysis of ancient frescoes at a pilgrimage site, as the interpretation did not seem to follow the evidence.

What Dominic wished to protest against was the habit, almost universal in Rome, of ascribing to a purely pagan origin house decorations of a pagan character.... a line is drawn rigorously between Christian and pagan art. And this is done too by quite learned archaeologists, without, so far as I can discover, a shadow of evidence. Indeed what evidence we have all points the other way. ${ }^{127}$

Pilgrims made the distinction between interpretation based on evidence and interpretation

\footnotetext{
${ }^{124}$ Roberts, A Roman Pilgrimage, 74-75.

${ }^{125}$ Ibid., 194.

${ }^{126}$ Starr, Pilgrims and Shrines, 265.

${ }^{127}$ Roberts, A Roman Pilgrimage, 69.
} 
made valuable due to its long history among Catholics. A section titled "Facts, Traditions,

Legends" in the appendix of Pilgrim Walks in Rome: A Guide to its Holy Places states

In visiting Rome's holy places and examining its religious treasures and memorials, it is important to distinguish between ascertained historical facts, venerable traditions and popular legends. The first no one questions. The second, especially when very ancient, command respect, though we must be prepared to hear occasionally doubts raised as to the value of such traditions, on account of the absence or insufficiency of early documentary evidence. We may then suspend our judgment, till the doubt is cleared up, or we may accept with reserve what tradition sanctions. The third may have an element of truth, that has been embellished by popular imagination; or they may be found to be positively false. In the latter case they must be at once rejected, but in the former, they may be usefully inserted in a Catholic book on Rome, noting, however, that they are only legends, and have no greater authority than popular belief. Recent historical research, while confirming the venerable and genuine traditions of Rome, has discovered that some of the popular stories and traditions about certain pictures, places, etc., are unreliable. ${ }^{128}$

The same author espoused the "value of the historical evidence" when touring pilgrimage sites. ${ }^{129}$ Some American Catholics at the turn of the twentieth century did not take traditions associated with pilgrimage sites at face value.

Pilgrimage guides and accounts used the work of scholars and historians to provide evidence for and situate interpretations of pilgrimage sites. When visiting the Red Sea where Moses allegedly parted the waters to lead the Israelites to safety, a pilgrim noted that "the earliest historians" wrote of a caravan route that bordered the sea at that location, giving credence to the site. ${ }^{130}$ Eliza Allen Starr wrote in the preface of her pilgrimage account that she consulted guidebooks by John Murray, Augustus Hare, and Karl Baedeker to add to her guide, as well as works by scholars Edouard de Bleser, P. Marchi, and M. de Rossi. ${ }^{131}$ While touring the Mamertine Prison in Rome, a pilgrim mentioned that Livy wrote of the site, legitimizing its

\footnotetext{
${ }^{128}$ Chandlery, Pilgrim Walks in Rome, 446.

${ }^{129}$ Starr, Pilgrims and Shrines, iv.

${ }^{130}$ Vetromile, Travels in Europe, Egypt, Arabia Petraea, Palestine and Syria, 120-121.

${ }^{131}$ Starr, Pilgrims and Shrines, v-vi.
} 
location. ${ }^{132}$ A pilgrimage account supported the authenticity of a wooden relic through the work of Giovanni Battista de Rossi and Orazio Marucchi, Italian archaeologists. ${ }^{133}$ The same account mentioned that "where the authenticity of some of these religious treasures has been questioned by recent writers, the fact is noted." 134 The account of the First American Catholic pilgrimage to Palestine included footnotes throughout, providing citations for its figures, statistics, and historical claims. ${ }^{135}$

Pilgrims gave importance to the expertise of pilgrimage guide authors. Eugene Vetromile published an account of his pilgrimage journey to Europe and the Middle East. On the title page under his name, his various credentials are mentioned including his membership to the Maine Historical Society, the New England Historic-Genealogical Society, and the Numismatic Antiquarian Society of Philadelphia. ${ }^{136}$ Vetromile would not have included his involvement in these historical enterprises, unless it they were significant to readers. His role as a historian and antiquarian legitimized his writings, demonstrating that pilgrims desired historical accuracy in the interpretation of pilgrimage landscapes.

Book reviews for pilgrimage guides further prove the emphasis pilgrims placed on accurate historical interpretations. A review for Pilgrims and Shrines by The Freeman's Journal in New York praised that the guide was "founded on authentic documents." ${ }^{137}$ Another review from The Catholic Universe proclaimed the guide's “interesting historical account of the places visited." 138 A review for Pilgrim Walks in Rome described the guide as "sufficiently well supplied with references for the student of archaeology" and "always distinguishing between fact

\footnotetext{
132 Chandlery, Pilgrim Walks in Rome, 177.

133 Ibid., 22.

134 Ibid., xi.

135 Pfeiffer, First American Catholic Pilgrimage to Palestine, 1889.

${ }^{136}$ Vetromile, Eugene. Travels in Europe, Egypt, Arabia Petrae, Palestine and Syria..

137 "Notices of the Press," in Pilgrims and Shrines by Eliza Allen Starr, vi.

${ }^{138}$ Ibid.
} 
and legend, between questionable and authentic antiquities." ${ }^{139}$ A book on the shrine of Our

Lady of Guadalupe in Mexico "furnished every evidence of being a record in which there are no exaggerations" and "one can not well question the proofs here presented with such minuteness and fidelity. The historical grounds for the devotion are certainly very convincing." ${ }^{140}$ The historical accuracy of pilgrimage accounts was important for American Catholic readers.

The interpretation of pilgrimage sites reached American Catholics at home through educational lectures and pilgrimage literature. Newspaper articles announced educational lectures at destinations around the United States on topics such as the 1900 American pilgrimage to Rome, a pilgrimage to Lourdes, a pilgrimage to the canonization of the Japanese martyrs, and a pilgrimage to the Oberammergau passion play. ${ }^{141}$ Newspapers also published pilgrimage accounts imbued with the history of the locale and its significance for Catholics. ${ }^{142}$ Publishers widely circulated photographs of holy places, making these pilgrimage sites familiar to American Catholics. ${ }^{143}$ Pilgrimage accounts were not only to be read by those on pilgrimage but

139 “Pilgrim Walks in Rome," Sacred Heart, November 14, 1903.

140 "Our Lady of America," Sacred Heart, February 5, 1898.

141 "The American Pilgrimage to Rome," The Catholic Telegraph, April 4, 1901; "Church News," The Catholic Telegraph, May 13, 1897; “St. Xavier Hall,” The Catholic Telegraph, April 29, 1897; James Duggan, Reminiscences and Impressions of a Visit to Rome, during the Canonization of the Japanese Martyrs, A Lecture, December 18, 1862, Misc Th 2, No 6, Printed Ephemera, The Catholic University of America, The American Catholic History Research Center and University Archives, Washington, DC; David Morgan, The Lure of Images: A History of Religion and Visual Media in America (London; Routledge, 2007).

${ }^{142}$ Antón M Pazos “A new golden age of pilgrimages", in Nineteenth-Century European Pilgrimage: A New Golden Age, edited by Antón M Pazos (New York and London: Routledge, 2020, 6. Advertisement for Pilgrimage to the Holy Coat of Treves publicized "with account of its history and authenticity" (Sacred Heart, December 17, 1892); Advertisement for Off to Jerusalem ("Book Table," The Monitor, January 26, 1907); Advertisement for The Pilgrim of Our Lady of Martyrs, a monthly magazine devoted to the interests of the Shrine of Our Lady of Martyrs (Our Lady of Martyrs: Auriesville, NY, 1890); Book on Holy Mountain of La Salette, France (Sacred Heart, October 26, 1901); Advertisement for Book on shrine of Our Lady of Guadalupe (Sacred Heart, February 5, 1898); Advertisement for bimonthly bulletin including description of the organization of pilgrimages (Sacred Heart, June 8, 1895).

${ }^{143}$ Advertisement for "A Photographic Pilgrimage to see His Holiness Pope Pius X" (Sacred Heart, August 8, 1914); "No need, my dear friend, of describing the [Lourdes] grotto to you. The pictures you have seen of it gives you as good an idea of it as I could" (Sacred Heart, December 6, 1890); Advertisement for "Photographic Panorama of Sacred History" (The Catholic Telegraph, April 5, 1894); "The photographs of this ancient church [Notre Dame Cathedral] have made the front of it familiar to every child in Christendom" (Starr, Pilgrims and Shrines, 23). 
were also tools for Catholics at home to perform spiritual pilgrimage. ${ }^{144}$ Through pilgrimage accounts and photographs, American Catholics formed an imagined landscape of pilgrimage sites abroad, one they referenced if they were fortunate enough to physically visit these destinations. $^{145}$

An analysis of American Catholic pilgrimage at the turn of the twentieth century reveals that pilgrimage has contributed in the preservation of tangible heritage. Historic structures and the material culture housed in their walls have been cared for by clergy members and lay people alike. Manuscript collections and books were delicately preserved, cased in cypress wood and wrapped in green silk. The faithful created new sites of pilgrimage, memorializing sacred events in tangible form. Burgeoning archaeological projects became pilgrimage destinations and sites of historical evidence. Pilgrimage groups huddled together, as guides interpreted sacred spaces on guided tours. The lone pilgrim interpreted pilgrimage sites for his/herself, making meaning out of the artwork on ancient walls. American Catholic pilgrims did not blindly accept every interpretation delivered to them, and they questioned the authenticity of pilgrimage sites and

144 "Others, who have no opportunity of visiting Rome, may also wish to read about its holy places, and to visit, at least in spirit" (Chandlery, Pilgrim Walks in Rome, xii); "A writer who has the gift of making stay-at-homes see through her eyes gives the Tablet a charming account of the recent English pilgrimage to Lourdes" (Sacred Heart, July 20, 1912); "We also, through your letters, have had a share by association in the enjoyments of your journey; and we look forward to a still greater share in them from the description you will doubtless give of what you have seen and heard" (Sacred Heart, July 12, 1890); "From this point, too, our readers must consider themselves not mere readers, but companions; seeing through our eyes, hearing through our ears" (Starr, Pilgrims and Shrines, 110); "In finishing our spiritual pilgrimage, let us unite ourselves to all the prayers which are being offered daily and hourly for peace, and God's blessing on the world" (Francis, Little Pilgrims to Our Lady of Lourdes, 183); "to those who must forego that pleasure, the perusal of this charming work will prove a delightful substitute for the actual journey" (Starr, Pilgrims and Shrines, vii).

145 "The Catholic reader will not skip any portion of this paper, even though he may have read many other descriptions of Lourdes and its pilgrimages" (Sacred Heart, March 24, 1894); "I shall not attempt to describe the stately ceremonials which take place in the great basilicas of Rome.... They are well known to every sightseer and have been described over and over again in books of travel and by newspaper correspondents" (Sacred Heart, January 26, 1895); "The history of the apparition of Our Lady of Guadalupe is no doubt known already to many of the readers of the Review, but it may not be amiss briefly to recapitulate it" (Sacred Heart, April 13, 1895); "Great care has been taken, in the description attached to these photographs, to delineate graphically the scenes portrayed, and to connect with them the familiar and important events of Bible history. This work thus becomes the greatest family educator" (The Catholic Telegraph, April 5, 1894). 
relics. Pilgrims desired to be presented historically accurate interpretations, based on evidence and fact. American Catholics at home encountered pilgrimage landscapes and its interpretation through educational lectures, pilgrimage literature, and photographs of sacred sites. As American pilgrims listened to guides and examined guidebooks, as American Catholics consumed pilgrimage accounts and attended lectures, the interpretation of tangible heritage was sustained and passed on for future generations to come. 


\section{CHAPTER THREE}

Worn Down by the Knees of Pilgrims:

Turn-of-the-Century Catholic Pilgrimage Practice as Intangible Heritage

There, at Rome, the pilgrim can strengthen his faith and excite his devotion more than elsewhere. He sees there before his eyes the city in which the first and principal Apostles preached with their lips the Gospel of Christ. He sees the city, the streets of which all the holy martyrs trod and consecrated with their blood, and adorn and protect with their relics. Who would not be moved at seeing the place where Peter was fastened to the cross, Paul beheaded with the sword, John cast into a vessel of boiling oil; where Peter said to Christ, 'Lord, whither goest Thou?'- the place where Laurence was roasted on the gridiron, Sebastian was shot with arrows; the house of St Agnes, of St Cecilia, the staircase of St Alexis? Yes, the holy steps which were in Pilate's house, up which staircase Christ went at the time of his bitter Passion, and which He sprinkled with His blood; the title of the Cross; the column to which He was bound?

_Pilgrim Walks in Rome: A Guide to its Holy Places,

P. J. Chandlery, 1903

As American Catholic pilgrims processed down cobbled streets towards holy places, they noted more than the ancient structures surrounding them. Kneeling before aging relics and mediaeval altars, pilgrims recognized that these objects had witnessed centuries of prayer and devotion. Pilgrimage sites preserved historic architecture, but they were also imbued with the memories of past events and characters. Pilgrims projected biblical history and the lives of the saints onto geographical landscapes, forming what public historians have defined as cultural landscapes. Pilgrims experienced cultural landscapes throughout whole cities, along historic pilgrimage routes, and at single sacred sites. Within these cultural landscapes, American Catholic pilgrims belted hymns, performed devotions, knelt reverently, kissed relics, and left ex-votos. Pilgrimage groups from across the globe wore badges and carried banners to distinguish themselves. But they also participated in these pious acts side by side with unfamiliar pilgrims, acknowledging their connection to all pilgrims surrounding them and to the pilgrims who came 
before. Americans at home delighted in the souvenirs and postcards sent from loved ones abroad, as the keepsakes allowed them to embed themselves into the cultural landscape, extending the effect of pilgrimage. At the turn of the twentieth century, pilgrimage practices encouraged American Catholics to engage with cultural landscapes through collective memory practices and embodied acts of memory. These elements of shared intangible heritage united all pilgrims, and through postcards and mementos also incorporated Americans home-bound, marking them all as members of the universal Catholic Church.

When on pilgrimage, American Catholic pilgrims remarked the affect of pilgrimage architecture and the beauty of sacred art. ${ }^{1}$ They often described a feeling of closeness to God in sacred spaces, asserting that "it is impossible to enter....without a feeling of holy awe and reverence," or they "had never been so near heaven before; not even on the highest mountain peak" or were "nearer to the supernatural than in any other place."2 However, the most common reflection pilgrims made on holy places was their connection to the past.

The faithful generally established pilgrimage sites in a location associated with a historic event. An article from The Sacred Heart Review proclaimed that "the thought of some day making a visit in person to the [Holy Land] itself where these natural events were enacted could scarcely fail to bring a thrill of more than common pleasure." 3 In their accounts, pilgrims harped on the fact that they were "on the very spot" an event occurred. Pilgrim Eugene Vetromile crossed the Red Sea and landed "on the very spot where the oppressed people of God, under the guidance of Moses and Aaron, had stopped....to behold the divided waters." ${ }^{4}$ When visiting the

\footnotetext{
${ }^{1}$ Starr, Pilgrims and Shrines, 33, 314; Roberts, A Roman Pilgrimage, 17-18.

2 Vetromile, Travels in Europe, Egypt, Arabia Petrae, Palestine and Syria, 156-157; Starr, Pilgrims and Shrines, 314; Sheehy, Notes on the Irish-Canadian Pilgrimage and Addresses, 47.

3 "In Holy Land," Sacred Heart, November 9, 1895.

${ }^{4}$ Vetromile, Travels in Europe, Egypt, Arabia Petrae, Palestine and Syria, 120.
} 
Church of the Holy Sepulchre, pilgrims described an iron cage indicating "the spot where the holy women stood" when Jesus's body was anointed for burial..$^{5}$ Marked were also the place where Jesus was nailed to the cross, the "hole in which our Saviour's cross was placed," the spot where the Virgin Mary and St John watched the crucifixion, "the spot where the executioners divided Our Lord's clothing," the spot where "the angel sat on the stone" when Jesus resurrected, and the place where Jesus appeared to St Mary Magdalena. ${ }^{6}$ In a church in Nazareth, spots were marked "indicating where the Virgin Mary stood and the Angel stood during the annunciation."7

Pilgrims noted the same importance ascribed to geographical locations when on pilgrimage to European shrines. Writing about the shrine in Lourdes, a pilgrim noted the "sacred spot where Mary declared Je suis l'Immaculée Conception, and showed herself to the saintly Bernadette." ${ }^{\prime 8}$ Another pilgrim visited "the spot where St Januarius suffered martyrdom, and saw the stone on which he was beheaded; it is yet sprinkled with blood." ${ }^{9}$ His "nerves were excited when [he] stood in the quadrangular portico, on the very threshold from which St Ambrose rebuked the Emperor Theodosius." 10 At the Roman church of San Clemente, "the story of the ancient church met [pilgrims] at the entrance," as pilgrims saw "the very staircase under which [St Alessio] lay in his own father's palace."11 Pilgrims venerated "the very spot upon which Saint Peter was crucified" at the church of San Pietro in Montorio. ${ }^{12}$ Close to the Latin Gate in Rome, pilgrims visited "the very spot where St John the Evangelist was immersed in a cauldron of boiling oil during the persecution of Domitian." 13 Pilgrims explored another location in Rome,

\footnotetext{
${ }^{5}$ Pfeiffer, First American Catholic Pilgrimage to Palestine, 1889, 11.

${ }^{6}$ Ibid., 111-121.

${ }^{7}$ Ibid., 171.

${ }^{8}$ Translated to "I am the Immaculate Conception. "Father O'Donnell's Letter," Sacred Heart, December 6, 1890.

${ }^{9}$ Vetromile, Travels in Europe, Egypt, Arabia Petrae, Palestine and Syria, 319.

${ }^{10}$ Ibid., 212.

${ }^{11}$ Starr, Pilgrims and Shrines, 305-306.

12 Ibid.

${ }^{13}$ Chandlery, Pilgrim Walks in Rome, 233.
} 
"the place where St Paul was detained for three hours before his execution, and the pillar of marble on which he was beheaded."14

These "spots" are remarkable precisely because of their association with past events and historic figures. Pilgrims make meaning of a geographical location because of its connection to history. To a history far more significant to the faithful because of its sacred character. Anthropologist James S Bielo has written about the action of pilgrims at sacred sites, observing that "it is less about re-animating the past as it is collapsing experiences of faith separated by time." If believers understand God to be outside of time, religious replication can be seen as "creating affective affinities between past and present." ${ }^{15}$ When pilgrims visited these places, they were able to imagine themselves within the historical scene as they were immersed in the environment in which the event took place. In a way, they could experience the event themselves in these sacred spaces.

Pilgrims regularly embedded themselves into the historic scene in their pilgrimage accounts. As pilgrims visited an amphitheater in Greece, the pilgrims "fancied ourselves gazing at those ferocious beasts grinding the bones of the martyrs, tearing their limbs, and sucking their blood! We imagined we heard their terrific roar, which amused thousands of spectators and made the eyes of Christians turn toward heaven." ${ }^{16}$ In Egypt, a pilgrim visited the fountain of Moses, said to be where Moses created a stream of water by striking a rock. "Here," the pilgrim wrote, "I imagined I saw Moses and Aaron, against whom the multitude murmured! Here on this desert they were fed with 'manna' and refreshed with the miraculous water issuing from this rock." ${ }^{17}$ At

\footnotetext{
${ }^{14}$ Sheehy, Notes on the Irish-Canadian Pilgrimage and Addresses, 61.

15 James S. Bielo, "Replication as Religious Practice, Temporality as Religious Problem," History and Anthropology 28, no. 2 (March 15, 2017): 141.

${ }^{16}$ Vetromile, Travels in Europe, Egypt, Arabia Petrae, Palestine and Syria, 319.

${ }^{17}$ Ibid., 122-123.
} 
a sanctuary in Italy, a pilgrim "seemed to hear the melodious echoes of hallowed feet and the whisper of holy voices that from the ancient days have entered and prayed within these angelguarded walls." 18 Pilgrim Eliza Allen Starr toured a monastery and wrote how "we can almost see the silent Benedictines of ages ago flitting through their dim length....we can see them after the compline song....each passing silently and meditatively into his own sacred and beloved cell." ${ }^{19}$ She also visited the home of St Benedict and asserted, "we could almost believe that we saw Saint Benedict also, seated on his rude bench, ready to receive, and to confound by the majesty of his presence." 20 At the Pudens house in Rome, Starr exclaimed,

how much must have taken place here!....not only did Saint Peter celebrate mass here, and not only were all the faithful fed from this altar, but here he presided at the early councils of the church. Here, too, he ordained those who were to carry the doctrine of Christ to all parts of the world; and here he anointed Saint Linus and Saint Cletus who were to succeed him. ${ }^{21}$

A pilgrim to St Peter's basilica imagined himself in a scene compressing multiple periods of history into one space. "Here St Ignatius of Loyola, St Philip Neri, St Dominic and others prayed in ecstasy and bedewed the ground with their tears. Here Kings and Emperors have come to lay their homage....Here in the dark days of persecution both Pontiff and the faithful have come to implore St Peter's help and protection." 22 When pilgrims entered into sacred space, they imagined themselves witnessing events from Church history.

\footnotetext{
${ }^{18}$ Stoddard, Two Celebrated Sanctuaries of the Madonna in Italy, 57.

${ }^{19}$ Starr, Pilgrims and Shrines, 124-125.

${ }^{20}$ Ibid., 107. Standing before the Church of SS Nereo, Achilleo, and Domitilla, Starr was "carried back to the time when SS Peter and Paul walked, bound, over this very road to martyrdom" (Ibid., 51-52).

${ }^{21}$ Ibid., 272-273.

${ }^{22}$ Chandlery, Pilgrim Walks in Rome, 18-19. Other examples include: During a mass held for a pilgrimage to a Cathedral in Albany, New York, a witness explained how "eyes were riveted on the kaleidoscopic drama unfolding within the sanctuary - for to Catholic faith the sacrifice of the Mass is drama and tragedy, no matter how it may be concealed under garniture of color and movement"( Souvenir of the Golden Jubilee and Solemn Consecration of the Cathedral of the Immaculate Conception, 1902, 16); A couple of pilgrims entered the Mamertine prison in Rome, where St Peter and Paul were imprisoned. "After we had gazed at the scene of the Apostles' imprisonment," the pilgrims turned to the Basilica of St Peter where "it was impossible.....as I knelt there, not to go back in thought to the moment in the life of Jesus when Peter burst out into his confession, 'Thou art the Christ"' (Roberts, A Roman Pilgrimage, 56, 87); During a visit to the shrine of Paray-le-Monial, where an alleged apparition of Jesus took place, a pilgrim described "there it was that the humble religious spent nights in prayers, hours in ecstasy, and her every
} 
Pilgrims were also reflecting on sacred persons' movements in the past. The language of walking in the "footsteps" of historic figures sometimes appeared in pilgrimage accounts. In Lourdes, pilgrims walked along a path "made sacred by the foot-prints of la petite Soubirous." 23 In reference to a pilgrimage undertaken by an American priest, a newspaper article chronicled his journey as "hallowed by divine and saintly and martyr footsteps." 24 The Roman Pudens house contained "the very floor.... which was trodden by the elder Pudens in his own house, and by his guests, Saint Peter and Saint Paul." 25 The catacombs provided the opportunity for a group of pilgrims to "[tread] in the very footsteps of numbers of martyrs." ${ }^{26}$ Also touring the catacombs, another pilgrim recognized that "the very stones on which we tread seem lustrous in the morning light from the touch of so many holy feet." ${ }^{27}$ As he meandered through the streets of Rome, the same pilgrim reflected "that we are treading in the footsteps of saints, on soil reddened with the blood of Martyrs" and "treading on the very stones that must have touched the feet of St Paul." 28

The impression of sacred bodies in materials such as stone made the historic presence of these figures tangible for pilgrims. A little church along the Appian Way in Rome allegedly contained the impression of Jesus himself. "The stone on which our Saviour actually stood, with the prints of his feet on it, is preserved in the church of St Sebastian." ${ }^{29}$ A stone in a Roman

moment in that chapel wrapt (sic) in the contemplation of God's goodness and love. There the three most famous of the apparitions took place of which she tells us, and which are now so familiar to all Catholics" (Sacred Heart, April 4, 1891).

23 "La petite Soubirous" is made in reference to the French peasant girl who allegedly witnessed an apparition of the Virgin Mary ("Father O’Donnell's Letter," Sacred Heart, December 6, 1890).

24 "Pilgrimage to Rome and the Holy Land and the Welcome Home," Sacred Heart, July 12, 1890.

${ }^{25}$ Starr, Pilgrims and Shrines, 272.

${ }^{26}$ Sheehy, Notes on the Irish-Canadian Pilgrimage and Addresses, 59.

${ }^{27}$ Chandlery, Pilgrim Walks in Rome, 223.

${ }^{28}$ Ibid., 91, 250.

${ }^{29}$ Sheehy, Notes on the Irish-Canadian Pilgrimage and Addresses, 59. 
church was said "to be in the impression of St Peter's knees." ${ }^{30}$ In Palestine, a pilgrim "saw the print of Our Lord's left foot" on the spot where the alleged resurrection took place. ${ }^{31}$ Such impressions made the past visible for pilgrims envisioning holy figures within sacred spaces.

American Catholic pilgrims found it important to acknowledge the fact that pilgrims had come before them, both connecting them to a Catholic heritage and giving legitimacy to these pilgrimage sites. The status of San Pietro in Vincoli as a historic pilgrimage site was significant, as a pilgrim proclaimed that the church "has been a place of pilgrimage since the fifth century, nor has the object of veneration once changed, the history of the devotion running thus." ${ }^{\prime 32}$ The Italian pilgrimage site of San Pancrazio experienced "pilgrims from Asia, Africa, America, as well as from Europe, and the islands in all the great oceans....[for] more than fifteen hundred years." ${ }^{33}$ St Peter's tomb, a pilgrim explained, was "to the early Christians, the most sacred spot in Rome and even in the world, outside Palestine. Thither they came in the dark days of persecution to ask St Peter's help." ${ }^{34}$ A newspaper article reported on a recent pilgrimage to venerate the Holy Coat in Treves, Germany. In the article, the journalist chronicled the history of pilgrims flocking to see the garment in the twelfth century, paralleling these historic pilgrims with modern pilgrims. ${ }^{35}$ In another article on an Irish site, a journalist was sure to mention that "the modern pilgrimage to Croagh-Patrick is only the revival of an ancient one which was recognized centuries ago at home and abroad, by priests and people, and princes and Popes." 36

\footnotetext{
${ }^{30}$ Chandlery, Pilgrim Walks in Rome, 189.

${ }^{31}$ Vetromile, Travels in Europe, Egypt, Arabia Petrae, Palestine and Syria, 193.

${ }^{32}$ Starr, Pilgrims and Shrines, 3.

33 Ibid., 294.

${ }^{34}$ Chandlery, Pilgrim Walks in Rome, 6.

35 "The Story of the Holy Coat of Treves," Sacred Heart, September 19, 1891.

36 "Thousands Climb Croagh-Patrick," The Monitor, August 7, 1909. Other examples include: A church built outside the walls of Rome was a site where "the faithful of the early Christian ages were accustomed to bring their many needs" (Starr, Pilgrims and Shrines, 60-61); According to a pilgrimage account, a painting of the Virgin Mary said to have been created by St. Luke the Evangelist experienced "veneration exceed[ing] 1,200 years" (Pfeiffer, First American Catholic Pilgrimage to Palestine, 1889, 43).
} 
The constant reference to the historicity of pilgrimage to specific sacred sites indicates that American Catholics desired to link contemporary pilgrimage practice to pilgrimage of the past.

Pilgrims wished to connect themselves to significant figures of Catholic tradition.

Accounts often listed both sacred and historic figures who had previously gone on pilgrimage to the site. The Emperor Otho III of the early eleventh century walked on pilgrimage to Mount Garganus, a sacred site in Italy. ${ }^{37}$ St Francis of Assisi and St Louis King of France visited the Holy House of Loretto. ${ }^{38}$ The church of St Francesco a Ripa was a pilgrimage destination for St Bridget of Sweden. ${ }^{39}$ Another account described "the long army of saints who crossed the sea and wandered over weary leagues of lands to come to [St Peter's Basilica]....to kneel where had knelt Athanasius and Augustine, Ambrose and Jerome, Dominic and Francis, Bridget and Wilfrid, Boniface and Anselm, Ignatius and Philip Neri - that surely is an ambition that ought to inspire every Christian." 40 The fact that pilgrims encountered the same sites these figures visited was valuable because through their active engagement, pilgrims inserted themselves within the sacred genealogy of the site.

Evidence of the presence of previous pilgrims was given by the wear on objects, steps, and architecture within pilgrimage sites. This tangible testimony of pilgrims who came before allowed contemporary pilgrims to actively engage in a communal pilgrimage experience stretching back thousands of years. The "beautiful old pavement" of the Santi Quattro Coronati Basilica was "worn by the steps of the faithful for so many hundreds of years." ${ }^{41}$ A guide leading pilgrims through the catacombs was sure to indicate the inscriptions "on the sides of the narrow

\footnotetext{
${ }^{37}$ Vetromile, Travels in Europe, Egypt, Arabia Petrae, Palestine and Syria, 243.

${ }^{38}$ Stoddard, Two Celebrated Sanctuaries of the Madonna in Italy, 45.

${ }^{39}$ Chandlery, Pilgrim Walks in Rome, 327-328.

${ }^{40}$ Roberts, A Roman Pilgrimage, 15.

${ }^{41}$ Starr, Pilgrims and Shrines, 179-180.
} 
passage-way; written hundreds of years ago, by pious pilgrims." ${ }^{42}$ Another pilgrimage party to the catacombs examined "the graffiti, or scribblings on the walls left by pious pilgrims in the fifth, sixth and seventh centuries," these markings "important as showing that we are approaching a place of more than ordinary sanctity." 43 The chair said to be the original chair of St Peter "bore marks of the pious violence of the faithful who had chipped portions of it away." 44 The tomb of Jesus in Jerusalem contained "surface and edges of which have been worn off by kissing and embraces of the pilgrims who for centuries have gathered here from all parts of the world." ${ }^{45}$ A pilgrim described how the tomb of St Rhadegund in France was "black from the hands of the many thousand pilgrims who have touched it." 46 Another tomb in France showed similar wear; at St Alpin's tomb, “there are yet three steps leading up to his resting-place that are much worn by the knees of pilgrims." 47

The wear and tear on pilgrimage sites illuminates an interesting tension between a pilgrim's experience and preservation. Some pilgrims even broke pieces off of shrines, to bring a sacredly imbued souvenir home with them. ${ }^{48}$ Doing so extended a pilgrim's experience past the confines of the physical journey and allowed the pilgrim to share the experience with loved ones at home. As much as visible weathering provoked pilgrims to link themselves with an atemporal Catholic community, it also impacted the preservation of pilgrimage sites for future generations. Shrine caretakers had to balance the desire to provide pilgrims with an authentic experience with that of preserving the historic structure. The wear-and-tear patina on sanctuaries bestowed an authenticity to the site that legitimized its connection to the past. But caretakers could not let the

\footnotetext{
${ }^{42}$ Starr, Pilgrims and Shrines, 84.

${ }^{43}$ Chandlery, Pilgrim Walks in Rome, 241.

${ }^{44}$ Ibid., 22.

45 Pfeiffer, First American Catholic Pilgrimage to Palestine, 1889, 112-113.

46 John M. Raphael, "My Pilgrimage to Lourdes," 354-355.

47 "St Alpin," Sacred Heart, February 15, 1896.

${ }^{48}$ Vetromile, Travels in Europe, Egypt, Arabia Petrae, Palestine and Syria, 187.
} 
historic structures show too much deterioration, both to ensure their preservation for future members of the Catholic community and because contemporary pilgrims noticed and criticized a lack of care.

Pilgrims sought authenticity when partaking in pilgrimage journeys, but they placed more value on the way in which these sites linked them to the past and to sacred figures, or in other words, to their heritage. When venerating holy places, pilgrims imagined the historic scene associated with the site. They envisioned the many pilgrims who participated in pilgrimage thousands of years before, and they acknowledged the long tradition of pilgrimage within the Church. For American Catholic pilgrims at the turn of the twentieth century, sacred history was embedded into pilgrimage landscapes. A pilgrim's account illustrates this well.

Words are not adequate, much less am I able to express the sweet emotions, the holy raptures of the Christian soul when, in presence of the places where he reads the short but comprehensive words: 'Here is the spot where stood the manger in which was laid the Infant Son of God;' or, 'Here the Word was made Flesh.' Who does not burst out in tears of joy, when pressing his lips on the sacred stone of the Holy Sepulchre; who can remain unmoved at the sight of Calvary, whereon took place the final scene of that awful drama, and what thoughts of regeneration do not refresh our minds, when we drink of Jordan's waters, when following the footsteps of Jesus along the shores of the beautiful Lake of Tiberias, or when taking a boatride on it with Christ as it were. What genuine sensations does the traveler not experience when he is winding his way along the zigzag path of the lovely Thabor, or visiting so many other places, sanctified by the presence, and illustrated by so many miracles of our Saviour. ${ }^{49}$

A French prayer book from the nineteenth century provides a visual example of pilgrims'

perceptions. Illustrations depicting the geographic landscapes of the Holy Land line the pious

pages, as representations of the sacred scenes that took place at the locale sit directly above (see

Fig. 1). Pilgrimage paths, cities, and sites are what we now call cultural landscapes.

The National Park Service defines cultural landscape as "a geographic area, including

\footnotetext{
${ }^{49}$ Pfeiffer, First American Catholic Pilgrimage to Palestine, 1889, v-vi.
} 
both cultural and natural resources and the wildlife or domestic animals therein, associated with a historic event, activity, or person, or exhibiting other cultural or aesthetic values." ${ }^{\prime 5}$ Pilgrimage imbues the physical landscape in which and to which pilgrims travel, with sacred associations and pious memories. UNESCO has recognized this fact in its inscription of the Sacred Sites and Pilgrimage Routes in the Kii Mountain Range in Japan as a cultural landscape. The listing includes three ancient shrines linked by pilgrimage routes, still much visited for ritual purposes. ${ }^{51}$ UNESCO inscribed the Sacred Mijikenda Kaya Forests in Kenya as a cultural landscape partly due to their role as focal points for Mijikenda religious beliefs and practices and Mijikenda's "sense of 'being-in-the-world." "52 The Sacri Monti of Piedmont and Lombardy in Italy are inscribed as cultural landscapes as well. These Catholic pilgrimage sites were created in the late sixteenth and seventeenth centuries and are listed for their "implementation of architecture and sacred art into a natural landscape for didactic and spiritual purposes." 53 All pilgrimage landscapes, not just the sites listed by UNESCO, should be considered cultural landscapes. American Catholic pilgrims at the turn of the twentieth century read pilgrimage landscapes as cultural landscapes. In an educational lecture recounting his pilgrimage to Rome, Rev James Duggan described his experience of the city.

If Cicero could say in his own day, that he was treading on the footprints of history when he walked her streets, how must those monuments have accumulated, and the interest attached to them increased, after the flight and vicissitudes of more than two thousand years! Rome, ancient and modern — pagan and Christian — classic and religious-lies before us. Wherever we tread, 'tis holy ground. The sacred dust of saints and martyrs hallows its soil. On every side the relics of the saints and servants of God inspire devotion, and fill the soul with holy awe. We bent in reverence over their sacred remains contained in ancient sarcophagi, or costly shrine. The sites and

\footnotetext{
50 “'Defining Cultural Landscapes,” National Park Service, accessed September 24, 2020, https://www.nps.gov/subjects/culturallandscapes/understand-cl.htm.

51 “Sacred Sites and Pilgrimage Routes in the Kii Mountain Range,” UNESCO, accessed September 24, 2020, https://whc.unesco.org/en/list/1142.

52 “Sacred Mijikenda Kaya Forests," UNESCO, accessed September 24, 2020, https://whc.unesco.org/en/list/1231.

53 "Sacri Monti of Piedmont and Lombardy," UNESCO, accessed September 24, 2020, https://whc.unesco.org/en/list/1068.
} 
even the walls of the houses in which they once dwelt are pointed out, the places of their martyrdom and sanctification well known. The magnificent shrines in which their precious relics repose, the glorious temples raised over their ashes, tell us of the piety of past ages. Every where we meet the most touching memorials of the good, and great, of every age, and almost of every clime. ${ }^{54}$

Another pilgrim, when taking in the Roman landscape, noted "the eye takes in one of those wonderful views of Rome, so full of historical interest, as well as of beauty, as to fix itself firmly upon the memory." 55 Regarding a Roman bridge called Ponte Molle, an account stated "two traditions help to invest this plain, strong bridge with peculiar interest....Here the miraculous cross appeared to [Constantine] the night before the battle, lighting up the horizon with its mystic radiance, and blazoning forth those prophetic words.... 'In this sign shalt thou conquer." ${ }^{56}$ At a bridge crossing the Tiber further south, a pilgrim proclaimed

how grandly the Tiber slows along today between the palaces on its banks! Think, too, how many martyrs have won a crown at this bridge: Saint Symphorosa under the Emperor Hadrian, Saint Sadas under Aurelian, Saint Calepodius under Alexander, and Saint Anthimius under Diocletian, were thrown into the Tiber from this bridge; and their bodies, floating down to the Island you admire so much in bright weather, were taken up by their fellow Christians and carefully preserved. ${ }^{57}$

An account of Our Lady of Martyrs shrine in Auriesville, New York included a description of the landscape. "The hill to the west, whose velvety slope was then a rough woodland, is the spot to which Father Jogues and René Goupil retired to pray, while the tuft of trees farther on marks the ravine into which René's dead body was thrown." 58 While on pilgrimage to the Holy Land, pilgrim Eugene Vetromile asserted "the country teems with historical and Scriptural reminiscences. The entire Holy Land can be said to be a continuous Sanctuary." 59 American Catholic pilgrims clearly understood pilgrimage landscapes to be what we call

\footnotetext{
${ }^{54}$ James Duggan, Reminiscences and Impressions of a Visit to Rome, during the Canonization of the Japanese Martyrs, A Lecture, 13.

${ }^{55}$ Starr, Pilgrims and Shrines, 17.

56 “An Art Pilgrimage Through Rome," The Catholic World, September 1873.

${ }^{57}$ Starr, Pilgrims and Shrines, 105.

${ }^{58}$ Our Lady of Martyrs: Auriesville, NY, 1890, 7.

${ }^{59}$ Vetromile, Travels in Europe, Egypt, Arabia Petrae, Palestine and Syria, 226.
} 
cultural landscapes today. Within these landscapes, pilgrims participated in intangible heritage such as collective memory practices. Collective memory concerns a community's shared pool of memories, knowledge, and information, passed on from one generation to the next. ${ }^{60}$ Pilgrimage is infused with collective memory practices, as sites often trigger memories regarding a particular saint, ritual, or past event. Often pilgrims recounted historical narratives or sacred legends and then performed rituals that memorialized a holy person at a shrine or sanctuary. Pilgrims recited hymns, chants, and prayers connected to particular sacred sites, inherited from the faithful who had come before. Pilgrimage was and still is a vehicle through which the faithful remember saints, sacred events, rituals, songs, and prayers.

Many holy spaces provided repositories for the memory of a holy figure. A visit to the pilgrimage site would prompt pilgrims to recount the saint's life story or partake in prayers or rituals associated with the figure. The memories of Roman saints were so vibrant that a pilgrim explained "during our stay in Rome, we have tried to live with the saints; we have visited their rooms, prayed at their shrines, followed in their footsteps." ${ }^{\prime 1}$ A pilgrim to Assisi remarked on the locale's association with St Francis noting that the Church of Assisi was "built in the memory and honor of Saint Francis" and that the saint's "memory is attached to every stone in it and whose name has made it famous throughout Christendom for seven centuries." 62 A famous sycamore tree in Egypt prompted memories of the Holy Family. The tree "had the honor of sheltering the Holy Family in their flight into Egypt," so a pilgrim "knelt on that spot which had

\footnotetext{
${ }^{60}$ Jeffrey K. Olick, Vered Vinitzky-Seroussi, and Daniel Levy, The Collective Memory Reader (Oxford: Oxford University Press, 2011).

${ }^{61}$ Chandlery, Pilgrim Walks in Rome, 448.

62 "Saint Francis Day Devoutly Observed in Assisi," Sacred Heart, November 10, 1917. Another pilgrim visited Assisi and saw "the stable in which St Francis was born, the miraculous cross, that spoke to him whilst in prayer," as well as locales associated with St Clara including the house in which she lived, the chapel where she said her prayers, the chair on which she sat, her breviary (prayer book), and her body (Pfeiffer, First American Catholic Pilgrimage to Palestine, 1889, 27).
} 
been sanctified by the sacred presence of the Holy Family," prayed, and mediated "on the great mystery of the flight into Egypt."63 At every step in a Roman street pilgrims basked in the memory of St Catherine of Siena, as they "seemed to follow the child Catherine" and "here....must be the spot where she stopped, while walking with her little brother Stephen, absorbed in the vision which appeared to her." ${ }^{44}$ The feast of St Martin triggered a French pilgrimage to Tours so pilgrims could come "to visit the holy places sacred to the memory of the saint." 65 The pavement of St Isidoro Church in Rome contained inscriptions "fragrant with the memory of sanctified lives." 66 Pilgrimage sites provoked memories associated with saints, inspiring pilgrims to contemplate sacred lives and reflect on how they could mirror sanctity in their own souls.

Indulgences, a Catholic doctrine that promised remission of temporal or purgatorial punishment upon reception, can very well be understood as a collective memory practice. ${ }^{67}$ At the turn of the twentieth century, American Catholic pilgrims collected indulgences as they made their way to pilgrimage destinations. ${ }^{68}$ Indulgences generally consisted of a combination of

\footnotetext{
${ }^{63}$ Vetromile, Travels in Europe, Egypt, Arabia Petrae, Palestine and Syria, 97-98.

${ }^{64}$ Starr, Pilgrims and Shrines, 216. Other examples include: Along the hill at the shrine of Our Lady of Martyrs, pilgrims found inscriptions memorializing St Catherine Tegakwita and St René Goupil doting the landscape (Our Lady of Martyrs: Auriesville, NY, 1890, 6); When visiting the Church of St Ambrose, a pilgrim proclaimed the "halo of holy associations crowding the ancient church" as it held the relics of St Ambrose, St Gervase, and St Protase (Starr, Pilgrims and Shrines, 43); St Patrick's presence was strongly felt and remembered on a pilgrimage to Lough Derg, Ireland. The site's name "recalls the patron Saint of Ireland" and "on this very island stones, undisturbed through centuries, [St Patrick] knelt and prayed and wept for Ireland's children....that until Judgment Day they might be faithful to the Faith he had taught them" ("St Patrick's Purgatory, Lough Derg," Sacred Heart, May 7, 1904).

65 "Fete of St Martin of Tours," Sacred Heart, February 12, 1898.

${ }^{66}$ Starr, Pilgrims and Shrines, 224.

${ }^{67}$ Purgatory is a Catholic doctrine that is defined as the purification that takes place between earthly life and heaven. See the Catechism of the Catholic Church, 1030.

${ }^{68}$ Pilgrims to Croagh-Patrick mountain in Ireland gained an indulgence through the climb, one which was granted by Pope Euguene IV in 1432 ("Thousands Climb Croagh-Patrick," The Monitor, August 7, 1909); The shrine of Our Lady of Good Counsel in Italy offered an indulgence, as long as one visited the shrine, recited three Hail Marys daily, kept an image of Our Lady of Good Counsel close by, and celebrated a mass (Stoddard, Two Celebrated Sanctuaries of the Madonna in Italy, 36); A pilgrim received partial indulgences throughout his pilgrimage to Palestine at places such as the Mount of Olives, a spot where the Virgin Mary allegedly prayed, a half ruined little house, and a cavern. These indulgences required the recitation of an Our Father and Hail Mary (Vetromile, Travels
} 
reciting certain prayers, engaging in specific sacraments (consuming of the Eucharist and confession), performing certain embodied acts, and visiting a holy place. Popes have granted indulgences associated with sacred sites throughout history. Indulgences are not changed or removed after every pontiff but are rather added by new Popes as time goes on. This means that the acts pilgrims performed to gain indulgences at pilgrimage sites have been enacted by pilgrims for thousands of years. Additionally, the prayers and acts tied to sacred spaces are passed down from generation to generation. The gaining of an indulgence is, therefore, a collective memory practice.

Hymns, chants, and prayers associated with particular pilgrimage sites form a distinct element of Catholic heritage, for they are passed down through the ages by way of pilgrimage performance. Pilgrims commented on their long history. In 1917, pilgrims participated in pilgrimage to Assisi for St Francis Day. The group proceeded "on their long weary way to the repetition of prayers in common, alternating with the chanting of hymns to tunes that have been in use for centuries." ${ }^{69}$ At St Patrick's Purgatory, a shrine in Ireland, "centuries have come and gone....but never, save for the briefest time, has the tradition of St Patrick's prayer and penance been interrupted." ${ }^{70}$ It was expected for pilgrims to the shrine of Our Lady of Lourdes to sing the Magnificat, other "accustomed hymns," and pray the Rosary at the sacred grotto. ${ }^{71}$ The monks of Monte Cassino in Italy and the pilgrims who visited the site sang from the same books that "have

\footnotetext{
in Europe, Egypt, Arabia Petraea, Palestine and Syria, 124, 192); Pilgrims participated in the practice of visiting the "seven greater churches" of Rome, a tradition that "can be traced back to the seventh century, and has been enriched by many Popes with very great indulgences." In order to receive the indulgence, pilgrims had to attend confession and communion, visit the churches, and pray five Our Fathers and Hail Marys (Chandlery, Pilgrim Walks in Rome, 439).

69 "Saint Francis Day Devoutly Observed in Assisi," Sacred Heart, November 10, 1917.

70 "St Patrick's Purgatory, Lough Derg," Sacred Heart, May 7, 1904.

${ }^{71}$ Francis, Little Pilgrims to Our Lady of Lourdes, 121; Clarke, Lourdes, Its Inhabitants, Its Pilgrims and Its Miracles, 69; John M Raphael, "My Pilgrimage to Lourdes," 358.
} 
been in daily use, according to their season, for more than three hundred years." 72 A pilgrim to

Rome described the importance of song in devotional practices.

Plain-song, for all sacred things, is incomparable: and for a very simple reason. Plain-song has grown up alongside the rites and the ceremonies of Holy Church: it is the living expression, in music, of that which is expressed also in the language of the Divine Office and the Missal, and in the ceremonies that have gradually become attached to the rites. Plain-song is not separable from the glorious actions of praise, prayer and devotion which it accompanies; plain-song is not so much subordinated to the words and ceremonies, as indistinguishably interwoven with them. For a man who has once heard plain-song properly sung it haunts for ever after the rites with which he first heard it associated. It is the soul of music - music in religion. ${ }^{73}$

During a mass, music prompted the same pilgrim to embed himself into a sacred past, "to the upper room at Jerusalem, when the Lord Jesus and his Apostles sang the Hallel....to the Mount of the Crucifixion, to the broken Tomb, and the Hill of the Ascension....back, far back, into the counsels of God, into the very mind and being of the Creator, the Inspirer."74

On pilgrimage, American Catholics often engaged in the Way of the Cross prayer exercise, sometimes known as the Stations of the Cross, connecting themselves to all the faithful who had prayed the same devotion throughout the centuries. ${ }^{75}$ It is based on pilgrimage practices along the Via Dolorosa in Jerusalem where pilgrims pray, chant, and reflect on Jesus's pathway to his crucifixion. There are fourteen stations, or stops, that commemorate scenes originating from the Bible and Catholic tradition. Each station incorporates portions of scripture, prayers,

\footnotetext{
${ }^{72}$ Starr, Pilgrims and Shrines, 132.

${ }^{73}$ Roberts, A Roman Pilgrimage, 91-92.

${ }^{74}$ Ibid., 92-93. Other examples include: According to a pamphlet, a devotion of the Rosary of the Infant of Jesus, a prayer associated with a miraculous statue in Prague, "has been practiced for the last 200 years" (Joseph Schaefer, Devotion to the Miraculous Infant Jesus of Prague, 1898, Box 1831, 1-21, \#10 Envelope, Printed Ephemera, The Catholic University of America, The American Catholic History Research Center and University Archives, Washington, DC, 29); Pilgrims who performed an annual pilgrimage to the Holy House of Loretto always entered the town chanting a particular hymn and ended in the basilica, whispering a specific prayer (Stoddard, Two Celebrated Sanctuaries of the Madonna in Italy, 42-43).

75 "Father O'Donnell's Letter," Sacred Heart, December 6, 1890; A Shrine in the Mohawk Valley: Shrine of Our Lady of Martyrs (New York: The Pilgrim Press, 1902), The Catholic University of America, The American Catholic History Research Center and University Archives, Washington, DC, 45.
} 
hymns, and meditations.$^{76}$ At the turn of the twentieth century, it was quite common for pilgrimage sites to offer the Way of the Cross devotion in the form of a series of statues or carved reliefs. The collection of prayers, scripture passages, hymns, and meditations associated with the Way of the Cross were passed down both as an oral and written tradition (see Fig. 2).

Because the devotion required pilgrims to meditate on scenes from the Passion of Jesus, they were encouraged to place themselves in the historic setting. A meditation in a nineteenthcentury devotional book proclaimed, "Alas! What do I see? My most amiable Jesus fallen under the ponderous weight of the cross. He lies extended upon the earth! $\mathrm{O}$ angels of heaven! Hasten to assist your Creator, my Redeemer. But alas! Instead of angels, raging executioners approach, strike His face with their fists, and kick Him in the most horrible manner!" present tense, an indication that pilgrims were to inhabit the biblical scene. A pilgrim at the shrine of Our Lady of Martyrs participated in the Way of the Cross and recounted, "we see the falls under the Cross, meet the agonized Mother, feel the nails crush through His hands and His feet; hear the dull thud of the hammer, and the words which will ring through the ages-'Father, forgive them, for they know not what they do." "78 In 1889, the clergy leading the devotional in Jerusalem wanted the exercise to appear as realistic as possible, so at the spot where the crucifixion took place, they fixed a human corpse to a cross. Then,

At the XIII station, where Christ is taken from the cross, a deacon took a pair of tongs, with which he extracted the nails from the hands, after which the arms hung down naturally; after loosening the feet he took the corpus down, laid it in a fine linen cloth, carried down from Calvary by four subdeacons, wearing very precious black dalmatics, and coming to the stone of the unction they laid the corpus thereon. Then the Franciscan Guardian embalmed it, as the body of Christ was embalmed according to the Jewish custom, and carried it into the Holy Sepulchre Chapel to

\footnotetext{
${ }^{76}$ Vetromile, Travels in Europe, Egypt, Arabia Petraea, Palestine and Syria, 164-165.

${ }^{77}$ Exercises of the Way of the Cross, As it is Performed at Jerusalem, and in the Colosseum at Rome (New York: Edward Dunigan \& Brother, 1855), The Catholic University of America, The American Catholic History Research Center and University Archives, Washington, DC, 8.

${ }^{78}$ Our Lady of Martyrs: Auriesville, NY, 1890, 9.
} 
represent burial. ${ }^{79}$

In a macabre manner, the faithful were participating in a kind of living history. One in which they embodied historical characters in order to immerse themselves completely into the biblical scenes. The physical acts undertaken throughout the devotional, whether walking from station to station, kneeling in prayer, or embalming a corpse, were important components of the pilgrimage practice.

Pilgrimage was chock full of embodied acts. Performance scholar Diana Taylor has written about the repertoire of embodied memory including performances, gestures, orality, movement, and dance. She argued that humans learn and transmit knowledge through embodied action and that performance plays a central role in conserving memory and consolidating identities. ${ }^{80}$ Through pilgrimage, pilgrims maintained and preserved embodied acts of memory, some of which originated thousands of years prior. It was only through the act of participating in pilgrimage that these embodied acts could be passed on to pilgrims to come.

The embodied acts that pilgrims performed at Lourdes when venerating at the shrine can be traced back to embodied acts undertaken by Bernadette, the young girl who experienced visions there. When Bernadette visited the grotto where the Virgin Mary appeared to her, she knelt with a candle in hand and prayed the rosary. ${ }^{81}$ She would then climb "on her knees up the slope which led to the niche, pausing, as she advances, to kiss the ground repeatedly. When she found herself beneath the hanging rose-bush she prostrated herself once more." 82 Pilgrims soon flocked to the grotto, to observe the pious girl. One day, Bernadette desired "the crowd to kneel with her and kiss the ground 'for sinners." "The multitude of people watching her were

\footnotetext{
${ }^{79}$ Pfeiffer, First American Catholic Pilgrimage to Palestine, 1889, 123.

${ }^{80}$ Diana Taylor, The Archive and the Repertoire: Performing Cultural Memory in the Americas (Durham and London: Duke University Press, 2003), xvi, xviii-xix.

${ }^{81}$ Francis, Little Pilgrims to Our Lady of Lourdes, 44.

82 Ibid., 68.
} 
accustomed to imitate her as nearly as they could. When she prayed they prayed with her; when she kissed the ground they did the same. Seeing her draw her rosary from her pocket....instantly each one took out his or her rosary and held it up in the direction of the Grotto." ${ }^{83}$ The Virgin Mary asked Bernadette to dig in the dirt near the grotto, resulting in a stream of water. The apparition then instructed Bernadette to "Go and drink in the spring and wash yourself there." 84 "Our Lady showed Bernadette unmistakably that she approved of the use of holy water," so pilgrims began to both drink it and bathe in it. ${ }^{85}$

Pilgrims at the turn of the twentieth century continued to perform the same embodied acts at the sacred grotto. In 1909, pilgrims "prostrate[d] themselves for a moment and kiss[ed] the ground - to comply with the wish of Our Lady when she said to Bernadette: 'You will pray for sinners, you will kiss the ground for sinners." " 86 Pilgrims continually prayed the rosary before the grotto, as Bernadette modeled ${ }^{87}$ Pilgrimage accounts of Lourdes included illustrations depicting the embodied acts performed at the site, including prostration, kneeling, outstretched arms, kissing and touching the grotto, praying the rosary, and collecting and bathing in the miraculous waters (see Figs. 3, 4, 5, and 6). The dissemination of these embodied acts through accounts and articles made them well-known to American Catholics who had not been to Lourdes. Familiarity with the movements allowed home-bound American Catholics to engage in embodied acts of memory, either at sites replicating the grotto in the United States or within their own household. Pilgrims continued to perform the same physical acts throughout the twentieth century, and they still do so today (see Fig. 7).

\footnotetext{
${ }^{83}$ Francis, Little Pilgrims to Our Lady of Lourdes, 100.

${ }^{84}$ Clarke, Lourdes, Its Inhabitants, Its Pilgrims and Its Miracles, 190.

${ }^{85}$ Francis, Little Pilgrims to Our Lady of Lourdes, 25.

86 "Memories of Lourdes," Sacred Heart, September 18, 1909.

87 “'A Visit to Lourdes," Sacred Heart, November 5, 1892.
} 
An article from The Sacred Heart Review outlined a unique embodied pilgrimage

practice in Echternach, Luxemburg. The town housed a shrine in memory of St Willibrord and a

Benedictine monastery founded by the saint in the seventh century. The annual pilgrimage

included an interesting element: a dance. The journalist described the movement for readers.

The boys come first, and jump up and down with the music. This perpetual jump they keep up all along the route, which, please to remember, it is not far from two miles in length. After them come the other dancing pilgrims, who have a step of their own...... fancy some eight hundred men and women of all ages, the old bent with years and gray-haired; the young full of life and vigor; the sick supported by their friends - all dancing in time to the music, three steps forward and two steps backward; or sometimes five steps forward and three backward. They are all silent and dance gravely with their hands by their sides, four or five in a row. All is recollection, and seriousness is marked upon every face. No roughness, no horseplay.... The whole thing is evidently done in a deeply religious spirit. ${ }^{88}$

The article stated that some dated the practice to the fourteenth century, while the author was of the opinion that it dated to the time of St Willibrord. UNESCO has recognized the significance of the pilgrimage practice, as it is inscribed in its intangible heritage list. According to UNESCO, the earliest documentation of the dance dates to the twelfth century. ${ }^{89}$

The act of ascending to a pilgrimage site on one's knees was a common practice at the turn of the twentieth century. An indulgence was granted in 1740 for all those who ascended on their knees to the Italian pilgrimage site of Varallo. ${ }^{90}$ The Holy Stairs in Rome, the famous twenty-eight steps allegedly brought from Jerusalem, was to only be ascended on one's knees. ${ }^{91}$ A wide piazza lay in front of the Roman Basilica of Constantine with thirty-five steps leading up to the grand ruins. "Pious pilgrims used to ascend these steps on their knees, and it is said that Charlemagne thus ascended them when he paid his first visit to Rome in 774." 92 Many pilgrims

\footnotetext{
88 “An Event at Echternach," Sacred Heart, May 22, 1897.

89 “Hopping Procession of Echternach," UNESCO, accessed September 25, 2020, https://ich.unesco.org/en/RL/hopping-procession-of-echternach-00392.

${ }^{90}$ Sacred Heart, May 14, 1898.

91 "The Lourdes of America," Sacred Heart, 24 July 1897.

${ }^{92}$ Chandlery, Pilgrim Walks in Rome, 8.
} 
who desired to visit the shrine of Our Lady of Guadalupe in Mexico traveled two and a half miles on their knees, carrying lighted candles in their hands. ${ }^{93}$ When pilgrims reached the Holy House of Loretto, it was custom "to make the circuit of the Holy House on their knees before entering it. There is a deep groove worn in the upper terrace, where the kneelers have followed one another in their solemn circuit."94

Pilgrims engaged in the act of kissing and kneeling before holy places, relics, or statues depicting holy persons. On the spot where St Peter allegedly turned back to Rome to face martyrdom after speaking to Christ, pilgrims "touch[ed] devout lips, so strongly is the mind affected by the sacredness of the spot." 95 A statue of Christ the Redeemer at the Roman Church of the Minerva was "so worn by the lips of the faithful, that the foot has been sandalled with bronze in order to preserve it." 96 At the Basilica of San Pietro in Vincoli, pilgrims encountered the chains of St Peter and they "kiss[ed] them with profound affection and respect" and then a clergyman "touch[ed] the neck of each pilgrim with the same iron collar worn by St Peter, say[ing] 'By the intercession of the blessed apostle, Peter, may God deliver thee from all evil.',97 On the Holy Stairs, pilgrims "kiss the spots where the marks of our Saviour's bleeding feet are seen through the little glass panes let into the woodwork with which the steps are protected". 98

\footnotetext{
93 "Our Lady of Guadeloupe," Sacred Heart, August 24, 1889.

${ }^{94}$ Stoddard, Two Celebrated Sanctuaries of the Madonna in Italy, 43.

${ }^{95}$ Starr, Pilgrims and Shrines, 80.

${ }^{96}$ Ibid.

${ }^{97}$ Ibid., 12.

${ }^{98}$ Chandlery, Pilgrim Walks in Rome, 68. Other examples include: Pilgrims at the Coliseum "used to kneel and kiss the soil that has drunk in the blood of Christ's innocent ones" (Ibid., 209); In the church of St Sernin, a glass case held the head of St Thomas Aquinas, which pilgrims "reverently kissed" (Sheehy, Notes on the Irish-Canadian Pilgrimage and Addresses, 49); On pilgrimage to the Church of the Holy Sepulchre in Jerusalem, pilgrims "knelt down, venerated, and kissed the Holy Grave" (Pfeiffer, First American Catholic Pilgrimage to Palestine, 1889, 97); Before the alleged scourging pillar of Jesus, a pilgrim "did not need the pious promptings of Padre Battista to make her kneel instantly on the circular slab of precious porphyry before this relic, once wet with the Blood of her Redeemer." Pilgrims were allowed to "see, venerate, and kiss the pillar" only once a year, on the Wednesday of Holy Week (Starr, Pilgrims and Shrines, 282-283; Pfeiffer, First American Catholic Pilgrimage to Palestine, 1889, 116).
} 
As they admired the grand Basilica of St Peter's, several pilgrims "passed the statue of Saint Peter sitting in his chair as pope, and they did not pass it without kissing the bronze foot, worn by the lips of those Christians who are not ashamed to own Saint Peter as their guide."99 "How many Saints have pressed their lips to this very foot and bent their heads to receive St Peter's blessing?" 100 The practice of kissing the foot of the statue of St Peter in Rome stretches back thousands of years, and pilgrims continue to perform it today (see Figs. 8 and 9).

When visiting holy places, pilgrims would often touch personal objects such as rosaries or medals to relics or objects sacredly imbued. Pilgrims touched their rosaries to the altar where St John was said to have boiled in a cauldron. ${ }^{101}$ At the Roman Church of the Capuchins, "the American boy and his sister kneeled beside the relics of [St Felix], dead for almost three hundred years, and reverently touched their rosaries to the shrine in which they lay." 102 When a pilgrimage group visited the Church of Santa Croce in Jerusalem, "all the crucifixes and rosaries of the little party" touched several cases housing relics. The same group toured the Roman catacombs, where "every rosary was drawn forth, to be laid upon this broken vial, or vase, which not only had contained, but still contained, the blood of a martyr." ${ }^{103}$ Before the reliquary enclosing the chains of St Peter, pilgrims reached out to touch their rosaries to the precious relic. ${ }^{104}$ Fac-similes of the chains were available for purchase "for a mere trifle," so clergymen could touch the copies to the veritable chains, becoming "assured partakers of the merits attached to the original relic." Numerous indulgences were attached to the wearing of these chains. ${ }^{105}$ Pilgrims who believed they had been miraculous healed at a sacred site would leave

\footnotetext{
${ }^{99}$ Starr, Pilgrims and Shrines, 69; Chandlery, Pilgrim Walks in Rome, 17.

${ }^{100}$ Chandlery, Pilgrim Walks in Rome, 18.

${ }^{101}$ Starr, Pilgrims and Shrines, 75.

102 Ibid., 217.

${ }^{103}$ Ibid., 199, 97-97.

${ }^{104}$ Starr, Pilgrims and Shrines, 12.

${ }^{105}$ Ibid., 15.
} 
objects behind, known as ex-votos, to provide a visual testament of the miracle. Articles and pilgrimage accounts listed the hodgepodge of material culture piled at shrines. Crutches and canes were the most common articles, but ex-votos also included bandages, glasses, marble tablets, candelabras, pictures, gold and silver hearts, embroideries, wax models of healed limbs, oil lamps, costly chains, crosses, trophies, and flags. ${ }^{106}$ American Catholics at home would have been aware of this practice, as illustrations of ex-votos gifted to holy places appeared alongside accounts of pilgrimage (see Figs. 10,11, and 12). These objects provide a memory of what allegedly took place in the past, and they encourage pilgrims to perform the same embodied act themselves, if they are fortunate enough to encounter the miraculous. Pilgrims have left ex-votos for millennia, and they continue to do so today (see Figs. 13 and 14).

Processions were used as a way to display a unified Catholic presence within a pilgrimage town. Processions were almost always included within pilgrimage journeys, whether from a train station to a pilgrimage sites or within a site's grounds. If pilgrims arrived collectively by train, the group frequently processed to the pilgrimage site. ${ }^{107}$ Processions often incorporated specific hymns or prayers that pilgrims recited as they marched in unison. ${ }^{108}$ By walking in procession, pilgrims distanced the site "temporally and spatially from the everyday." ${ }^{109}$ Processions followed a determined path, allowing pilgrims to walk along the same

\footnotetext{
${ }^{106}$ Dorion, "Pilgrimage to Sainte Anne de Beaupre: Mother of the Virgin Mary"; "A Visit to the Shrine of St Anne," Sacred Heart, August 29, 1896; "The Lourdes of America," Sacred Heart, July 24, 1897; "In the Alps," Sacred Heart, March 27, 1897; "Our Lady of Guadalupe," Sacred Heart, October 19, 1895; Starr, Pilgrims and Shrines, 19; Sheehy, Notes on the Irish-Canadian Pilgrimage and Addresses, 46; Clarke, Lourdes, Its Inhabitants, Its Pilgrims and Its Miracles, 27.

${ }^{107}$ Our Lady of Martyrs: Auriesville, NY, 1890, 3.

${ }^{108}$ In the processions at Lourdes pilgrims sang the "Ave Maria" (Sheehy, Notes on the Irish-Canadian Pilgrimage and Addresses, 47; "Pilgrims at Lourdes," Sacred Heart, July 20, 1912). In the processions at Our Lady of Martyrs pilgrims prayed the Litany of the Blessed Virgin (Our Lady of Martyrs: Auriesville, NY, 1890, 4). The procession in Jerusalem on the day of Pentecost requires the singing of "Veni, Sancte Spiritus" (Vetromile, Travels in Europe, Egypt, Arabia Petrcea, Palestine and Syria, 262).

${ }^{109}$ Simon Coleman, "From England's Nazareth to Sweden's Jerusalem: Movement, (virtual) landscapes and pilgrimage" in Reframing Pilgrimage: Cultures in Motion, Simon Coleman and John Eade, eds. (New York and London: Routledge, 2004), 58.
} 
streets as pilgrims had in ages past. ${ }^{110}$ Processions did play a role in historic pilgrimage, as seen in figure 15 and 16 . The replication of processions at pilgrimage sites came from the faithful's desire to invoke embodied actions and collective memory practices that connected themselves to an established Catholic tradition or heritage. As pilgrims processed through public streets, nonCatholics were sure to witness the large crowd of faithful Catholics. Pilgrimage groups carried banners and flags, identifying with their nationality or parish community. However, the many pilgrimage groups made up the larger company of Catholic pilgrims who walked side by side as they devoutly prayed and chanted.

Collective memory practices and embodied acts of memory were significant for pilgrims because these acts, transmitted from generation to generation, provided them a sense of identity and continuity. As in all intangible heritage, pilgrimage practices were constantly recreated by the faithful in response to their environment and their perceptions of history. Collective memory and embodied acts were a grassroots form of engagement with the past that allowed pilgrims to participate in their Catholic heritage. Through intangible heritage practices, pilgrims recognized the value they placed on the tenets of their faith. Pilgrims were confident that they were actively engaging in the past as they replicated ancient rituals, the foundation for their own pilgrimage. Embodied experiences involving touch, smell, sound, and sight legitimized a pilgrim's relationship with pilgrimage destinations. Embodied acts of memory ensured that pilgrims gained the blessing of a holy place by way of mimesis, or imitative action, of the sacred figure. Intangible heritage practices encouraged pilgrims to merge biblical or hagiographical realities with contemporary lived reality, evoking the feeling of God's presence.

The varied collective memory practices and embodied acts that pilgrims participated in

\footnotetext{
${ }^{110}$ Vetromile, Travels in Europe, Egypt, Arabia Petrae, Palestine and Syria, 262-263; Sheehy, Notes on the IrishCanadian Pilgrimage and Addresses, 50-51; Coleman, "From England's Nazareth to Sweden's Jerusalem," 56.
} 
along their religious journey connected them to the universal Church through a shared heritage. American Catholics recognized this fact and proclaimed the unity of the Catholic faithful in accounts of pilgrimage. An article in The Sacred Heart describing a Christmas pilgrimage announced that Rome was

thronged with men of all nations, speaking almost every living tongue and wearing many varieties of costume, but all united in one faith under one living authority. These celebrations cannot fail to impress the most thoughtless with both the universality and the visible unity of the true Church of God upon earth. ${ }^{111}$

In reference to the upcoming pilgrimage to Rome in honor of the Pope Leo XIII's Jubilee, a journalist explained "this Jubilee will unite the Catholics of all countries in sentiments of a common faith and a profound devotion to the Holy See. It will bear witness to the world of our strength and unity." ${ }^{112}$ When attending a mass on pilgrimage to France, a pilgrim remarked, "How consoling it was to realize that mass was the same in Europe as in America, and were just as much at home before an altar in Paris, as before an altar in Boston or Chicago!" ${ }^{113}$ A clergyman on pilgrimage to Rome noted the priests from many countries waiting their turn to celebrate mass in St Peter's Basilica, stated it showed "a beautiful picture of the divine unity of the Church." 114 A pilgrim to Lourdes explained what one witnessed at the pilgrimage site.

He will see countless crowds of pious pilgrims gather round the Grotto with strong and firm faith in the miraculous power to heal of the water that flows there. He will see the assemblage, from every part of France and the neighboring countries, of thousands and ten thousands who come to ask for some favor from the Mother of God....He will hear them shouting out in sonorous refrain the hymns of Catholic devotion and the heartfelt expressions of Catholic loyalty. ${ }^{115}$

Although pilgrims distinguished themselves through pilgrim badges, in the act of venerating sacred spaces through embodied acts and collective memory practices side by side with others

\footnotetext{
111 “Christmas-Tide in Rome,” Sacred Heart, January 26, 1895.

112 "The General Intention," Sacred Heart, January 7, 1893.

113 Starr, Pilgrims and Shrines, 24.

${ }^{114}$ Sheehy, Notes on the Irish-Canadian Pilgrimage and Addresses, 60.

115 Clarke, Lourdes, Its Inhabitants, Its Pilgrims and Its Miracles, 6-7.
} 
from across the globe, pilgrims recognized their shared Catholic heritage. Through pilgrimage, American pilgrims identified as belonging to the universal Catholic Church.

American Catholics at home were able to participate in this shared Catholic heritage through souvenirs and postcards brought back from loved ones. Religious scholar Crispin Paine has written about the encapsulation of memory in objects. Paine argued that religious souvenirs brought sacred stories to life and carried their own kind of sanctity. ${ }^{116}$ Anthropologist Hillary Kaell asserted that souvenirs, particularly those consisting of natural objects, do more than evoke memories but rather "open a channel for divine presence in the home." ${ }^{117}$ Even manufactured souvenirs can have a metonymical quality, if purchased at a pilgrimage site. ${ }^{118}$ The pilgrimage landscapes depicted in postcards allowed for Americans at home to engage in "collective visual piety." ${ }^{119}$ Souvenirs and postcards sacralized domestic space, linking it with pilgrimage sites.

American pilgrims purchased souvenirs at pilgrimage sites infused with sanctity for both themselves and friends and family back home. Pilgrims regularly touched souvenirs to sacred spaces or relics to imbue them with divine presence. Shops and booths selling rosaries, crucifixes, and other devotional objects lined the streets winding through pilgrimage towns, encouraging pilgrims to purchase an item and carry it on their pilgrimage. ${ }^{120}$ Loved ones at home cherished these precious gifts. A priest in Boston went on pilgrimage to the Holy Land and brought back souvenirs for his congregation. "He presented to each one at the different masses, a rosary of olive wood or of stone from the Holy Land; rendered doubly precious by the Holy

\footnotetext{
${ }^{116}$ Crispin Paine, Religious Objects in Museums: Private Lives and Public Duties (New York and London: Bloomsbury, 2013), 55.

${ }^{117}$ Kaell, Walking Where Jesus Walked, 177.

${ }^{118}$ Michael Stausberg, Religion and Tourism: Crossroads, Destinations, and Encounters (New York: Routledge, 2011), 206.

${ }^{119}$ Morgan, The Lure of Images, 167.

120 “Auriesville," Sacred Heart, August 31, 1895; Chandlery, Pilgrim Walks in Rome, 12; Pfeiffer, First American Catholic Pilgrimage to Palestine, 1889, 35; Clarke, Lourdes, Its Inhabitants, Its Pilgrims and Its Miracles, 42.
} 
Father's blessing and the fact of having been touched to the sacred spots hallowed by the living presence of the Divine Master during his earthly sojourn." ${ }^{121}$ Pilgrim Eliza Allen Starr visited a church where a woman was selling some medals of St Catherine. According to Starr they were cheap medals but "taking them, not for ourselves only but for those who, we knew, really loved Saint Catherine, we carried them back to the church and laid them on the spots hallowed by her visions." Starr then saw some visiting priests and asked them to bless the medals, "which they did in this very chapel." 122 An American pilgrimage group in Rome was granted an audience with the Pope, and they brought "their religious articles, such as rosaries, crosses and crucifixes, in their hands, which the pilgrims bought in the Eternal City" in order to imbue them with a Papal blessing. ${ }^{123}$ The same group visited the Holy House of Loretto and offered their religious articles to the Bishop there, who blessed them. ${ }^{124}$ A pilgrim to Lourdes recounted that "every pilgrim is sure to carry away some mementoes of Lourdes, at the least one or two objects of piety, and sometimes whole packets of pictures, rosaries, medals, statuettes, etc." 125

The connection these souvenirs had to sacred sites or holy figures made them powerful instruments of piety and devotion. American Catholics could recite hymns and prayers or engage in embodied acts mirroring the actions undertaken by pilgrims at pilgrimage sites. Because of the souvenir's association with the holy site, the embodied acts of memory performed in American households tied the American faithful to pilgrims physically visiting the site in question, as well as to the universal faithful participating in the same acts within their own homes throughout the world.

\footnotetext{
121 "Pilgrimage to Rome and the Holy Land and the Welcome Home," Sacred Heart, July 12, 1890.

122 Starr, Pilgrims and Shrines, 219.

${ }^{123}$ Pfeiffer, First American Catholic Pilgrimage to Palestine, 1889, 35.

124 Ibid., 229.

${ }^{125}$ Clarke, Lourdes, Its Inhabitants, Its Pilgrims and Its Miracles, 49.
} 
American pilgrims regularly sent back postcards while on pilgrimage. ${ }^{126}$ Many postcards illustrating pilgrimage sites displayed both the pilgrimage landscape and the embodied acts performed during pilgrimage. One postcard depicted crowds of pilgrims venerating the grotto in Lourdes (see Fig. 17). Its caption read "The grotto before the depart of the Procession," and pilgrims are captured clutching candles, kneeling, and praying before the statue of the Virgin Mary. The perspective provided by a 1900 postcard from Lourdes displayed the statue of the Virgin Mary top and center and pilgrims venerating the sacred place along a metal fence (see Fig. 18). However, the photograph was taken from quite far back, exhibiting rows of uninhabited benches in the foreground of the frame. These empty seats invited the viewer into the space, allowing for devotion of the site outside its geographical bounds. A postcard from Paray-leMonial, France where another apparition of the Virgin Mary was said to have taken place, illustrated the apse of its chapel (see Fig. 19). This photograph appears to have been taken from the chapel's altar rail. From this perspective, viewers can imagine themselves kneeling at the altar rail (the traditional embodied act associated with the location) and piously gazing at the tomb of St Margaret Mary, located to the right of the postcard. Other pilgrimage elements are visible, such as the flags left by pilgrims draped above the tomb and the candles lit by the faithful. A postcard dating from 1910 illustrated a procession to Hastings Castle in Sussex, England (see Fig. 20). Clergymen dawning white cassocks and black birettas lead a densely packed crowd of pilgrims along a winding path. Taken from above, the image did not necessarily invite the viewer to follow the crowd but rather memorialized the movement, noise, and landscape associated with pilgrimage processions. Even if the postcard recipient did not participate in the religious parade, the image was a reminder of a unified Catholic populace.

${ }^{126}$ Pfeiffer, First American Catholic Pilgrimage to Palestine, 1889, 32. 
By partaking in pilgrimage ritual in spirit, home-bound Americans were united with the universal Church through inherited shared heritage. In most of these scenes, pilgrims were engaged in the embodied acts of memory associated with each pilgrimage site. Americans receiving similar postcards were not only presented with an illustration of pilgrimage landscape but also a visualization of how pilgrims participated in pilgrimage practices when visiting sacred space. Such compositions encouraged the receiver to imagine themselves within the scene, to become a spiritual participant.

At the turn of the twentieth century, American Catholic pilgrims traveled to sanctified structures embedded in pilgrimage landscapes. Pilgrims perceived pilgrimage sites as cultural landscapes; geographic spaces intimately interwoven with sacred stories. When venerating holy places amid pious chanting and wafting incense, pilgrims imagined themselves in historic scenes, perceiving the site's link with the past. The fact that generations of pilgrims had come to pay their devotions in the same places was immensely significant for pilgrims, as it connected them to an ancient Catholic heritage. Collective memory practices and embodied acts of memory were valuable pilgrimage practices for Catholic pilgrims. The acts of memory had been passed down hundreds or thousands of years, and by participating in pilgrimage, contemporary pilgrims continued to pass it down. Because pilgrims gifted souvenirs and postcards to loved ones back home, Americans within the US were able to engage with objects imbued with the power of pilgrimage sites. Pilgrimage practices united physical and spiritual pilgrims from all over, through a shared Catholic heritage. As American Catholic pilgrims knelt and sang, as they devoutly pressed their lips to relics and reverently participated in processions, they engaged in intangible heritage practices that filled them with pride and unified them to a global Catholic community. 


\section{List of Figures}

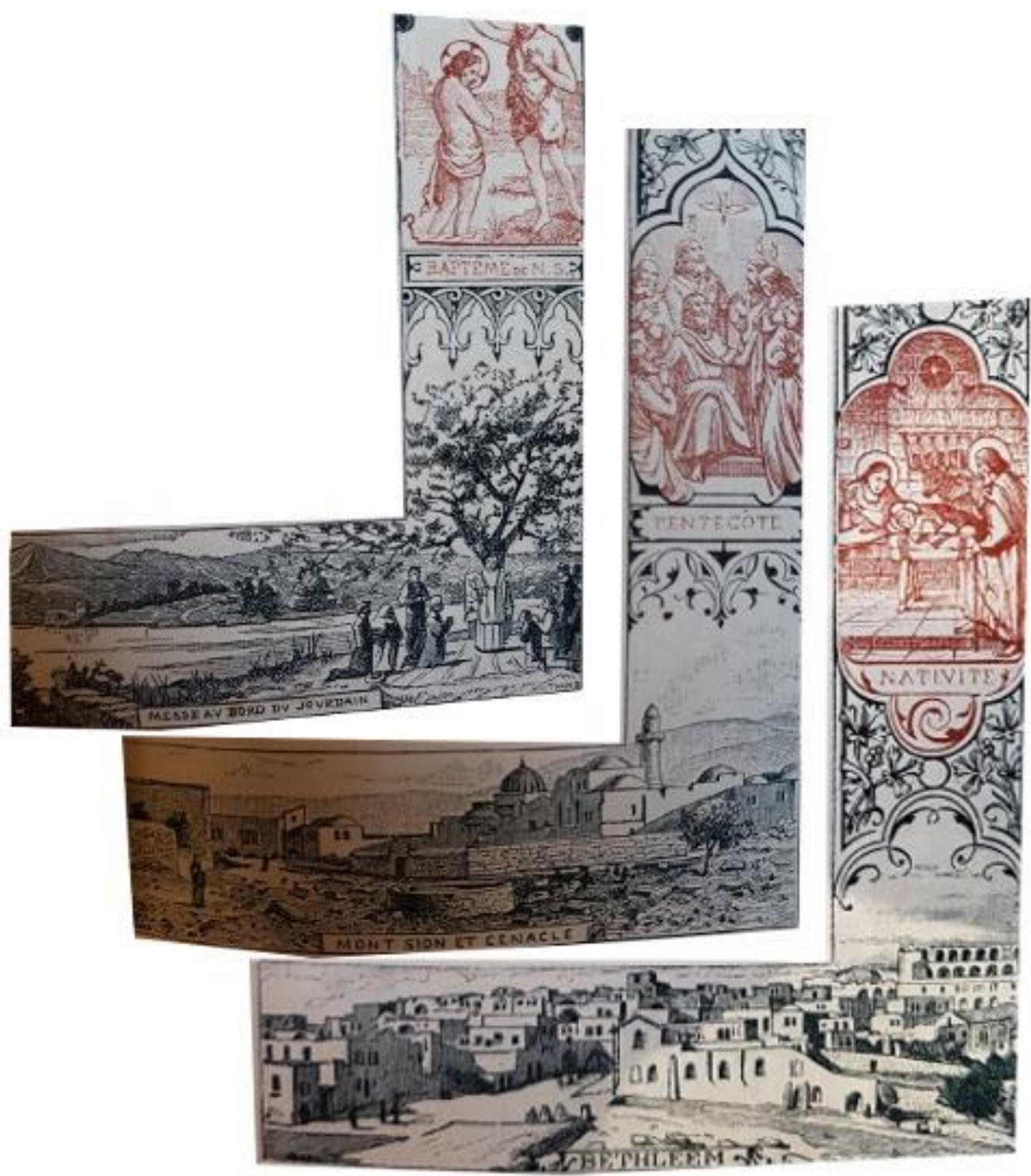

Figure 1: Details in Missel des lieux Saints. Limoges, France: Dalpayraz et Depelley Editeurs, 1894. Accessed September 24, 2020.

https://www.etsy.com/ca/listing/757681937/french-antique-christian-prayerbook?ga_order=most_relevant\&ga_search_type=all\&ga_view_type=gallery\&ga_search_ query=catholic+pilgrimage \&ref=sr_gallery-10-13\&organic_search_click=1. 


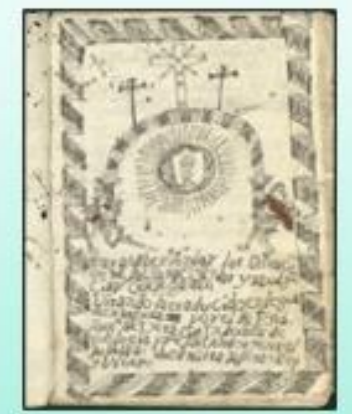

1680

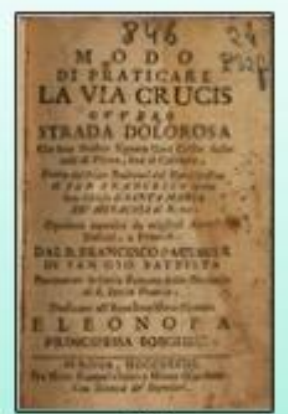

1733

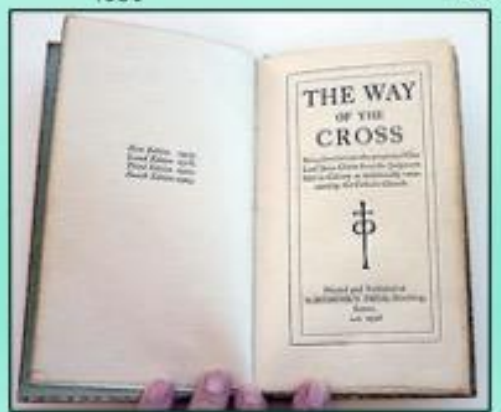

1926

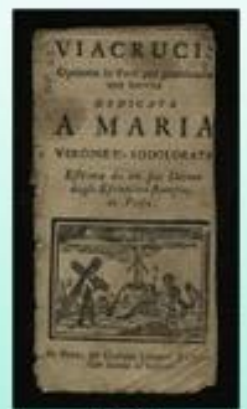

1753

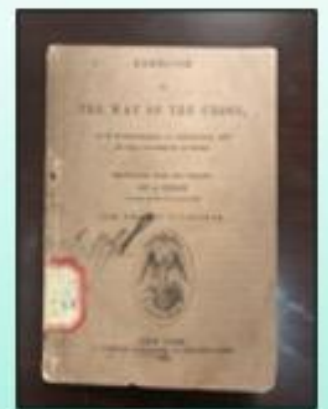

1855

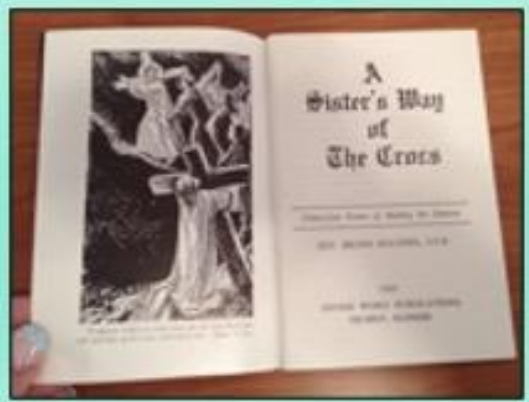

1960

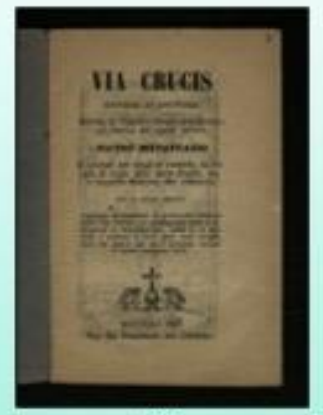

1877

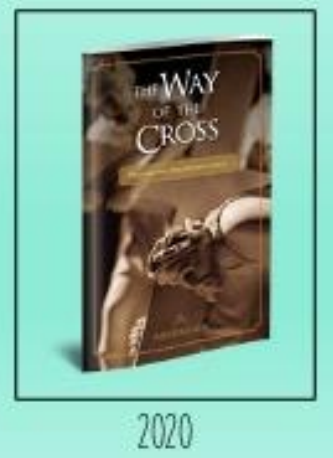

Figure 2: The Way of the Cross devotional books containing the prayers, scripture passages, hymns, and meditations associated with the prayer exercise. Top left to right: Book dating from 1680 taken from John F. Schwaller's "The 'Via Crucis en mexicano."” The Americas 74, no. 2 (April 2017): 119-137; Book dating from 1733 taken from Modo di Praticare La Via Crucis (Rome: Per Gio, 1733); Book dating from 1753 taken from Via Crucis:Operetta in Verli per pratticarla con brevitá (Fano: Giuseppe Leonardi, 1753); Book dating from 1855 taken from Exercises of the Way of the Cross, As it is Performed at Jerusalem, and in the Colosseum at Rome (New York: Edward Dunigan \& Brother, 1855); Book dating from 1877 taken from Via Crucis: Brevissima ed Affettuosa (Bologna: De' Franceschi alla Colomba, 1877); Bottom left to right: Book dating from 1926 taken from The Way of the Cross (Sussex: St Dominic's Press, 1926); Book dating from 1960 taken from Rev Bruno Hagspiel's A Sister's Way of The Cross (Techny: Divine Word Publications, 1960); Book dating from 2020 taken from "The Way of the Cross," Ascension Press, accessed April 23, 2020, https://ascensionpress.com/products/the-wayof-the-cross-praying-the-psalms-with-jesus. 


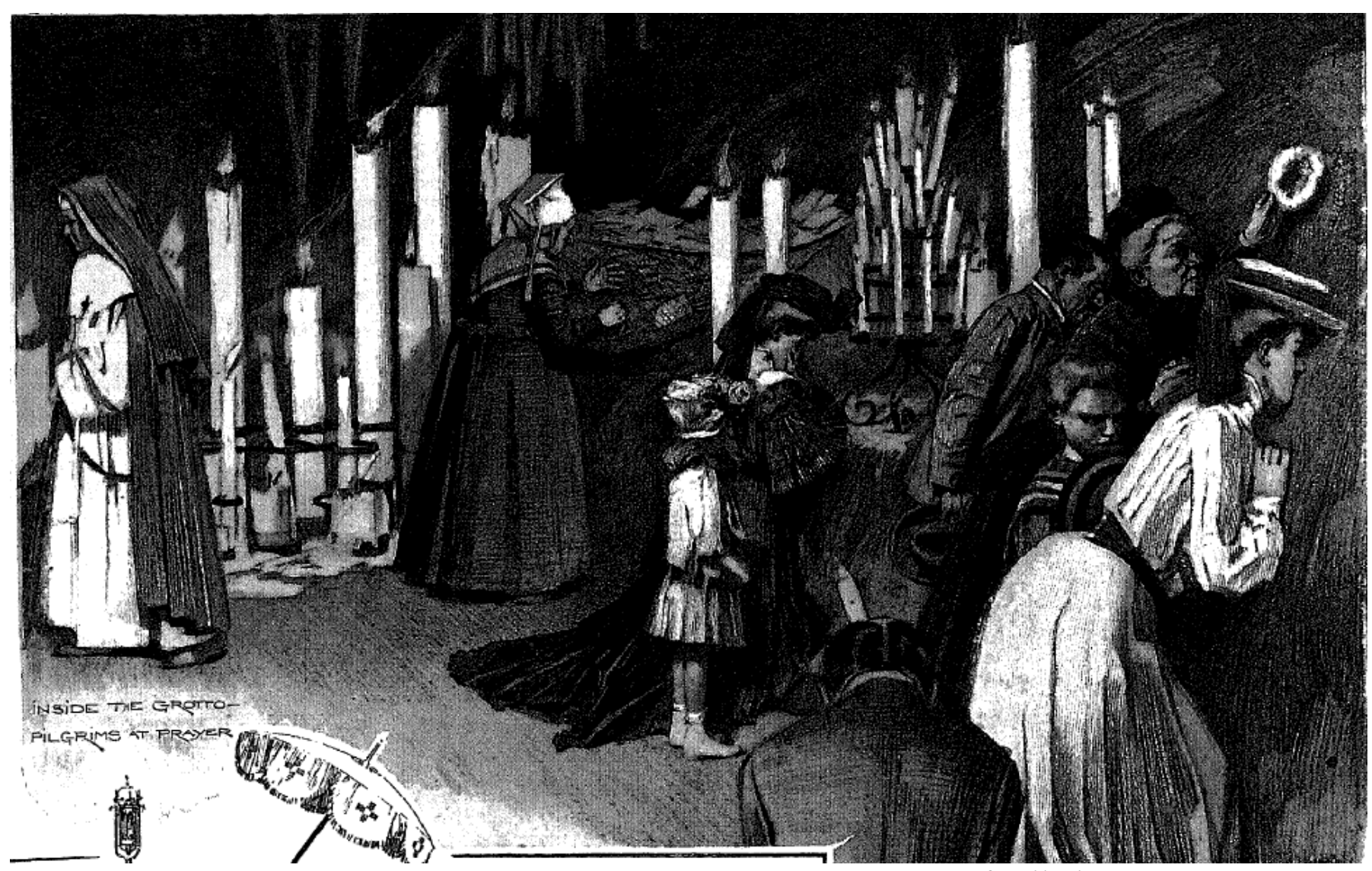

Figure 3: Inside the Grotto, Pilgrims at Prayer. Image taken from page 385 of "Pilgrims at Lourdes," The Graphic, September 23, 1905. 


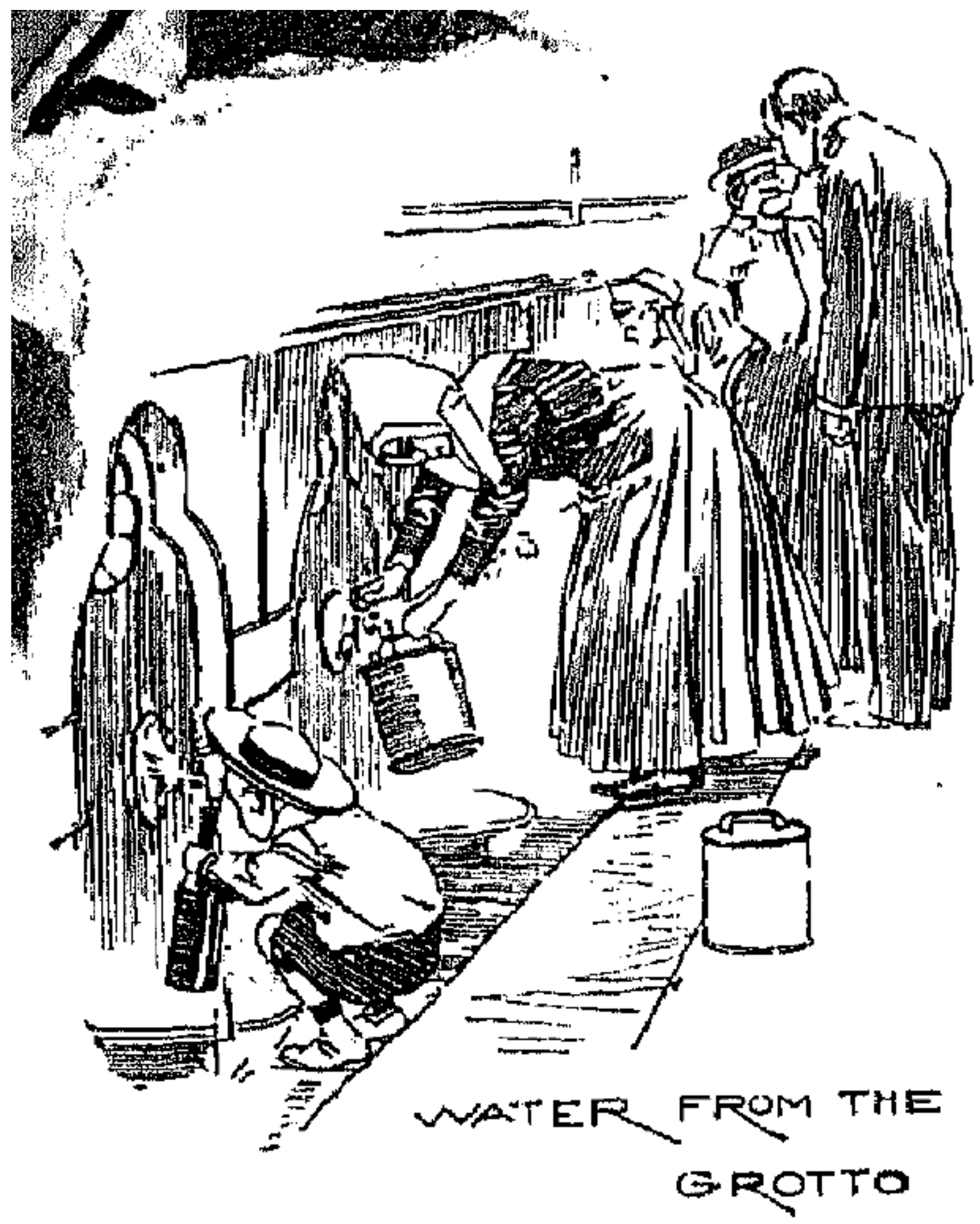

Figure 4: Water from the Grotto. Image taken from page 385 of "Pilgrims at Lourdes," The Graphic, September 23, 1905. 


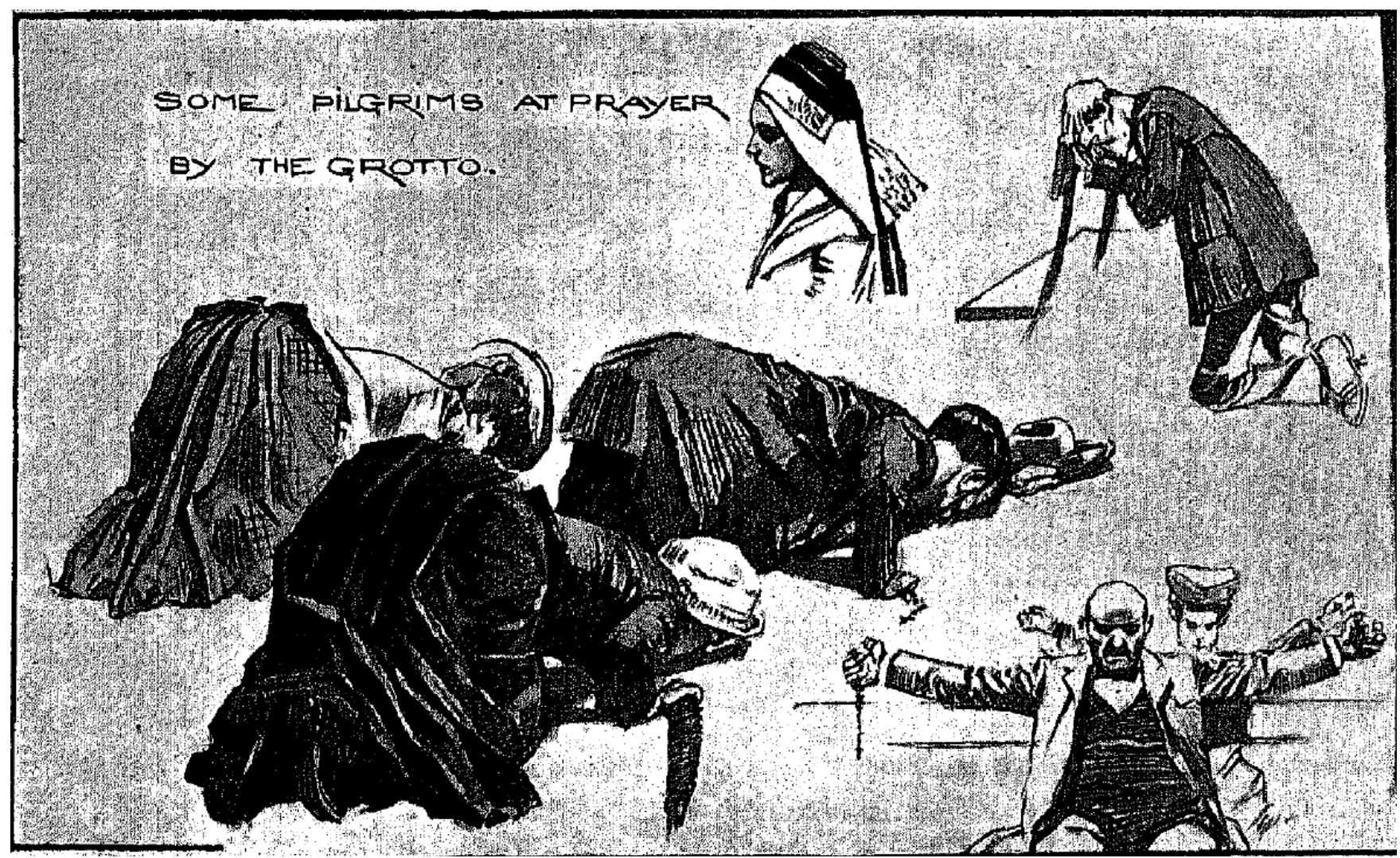

Figure 5: Some Pilgrims at Prayer by the Grotto. Image taken from page 386 of "Pilgrims at Lourdes," The Graphic, September 23, 1905. 


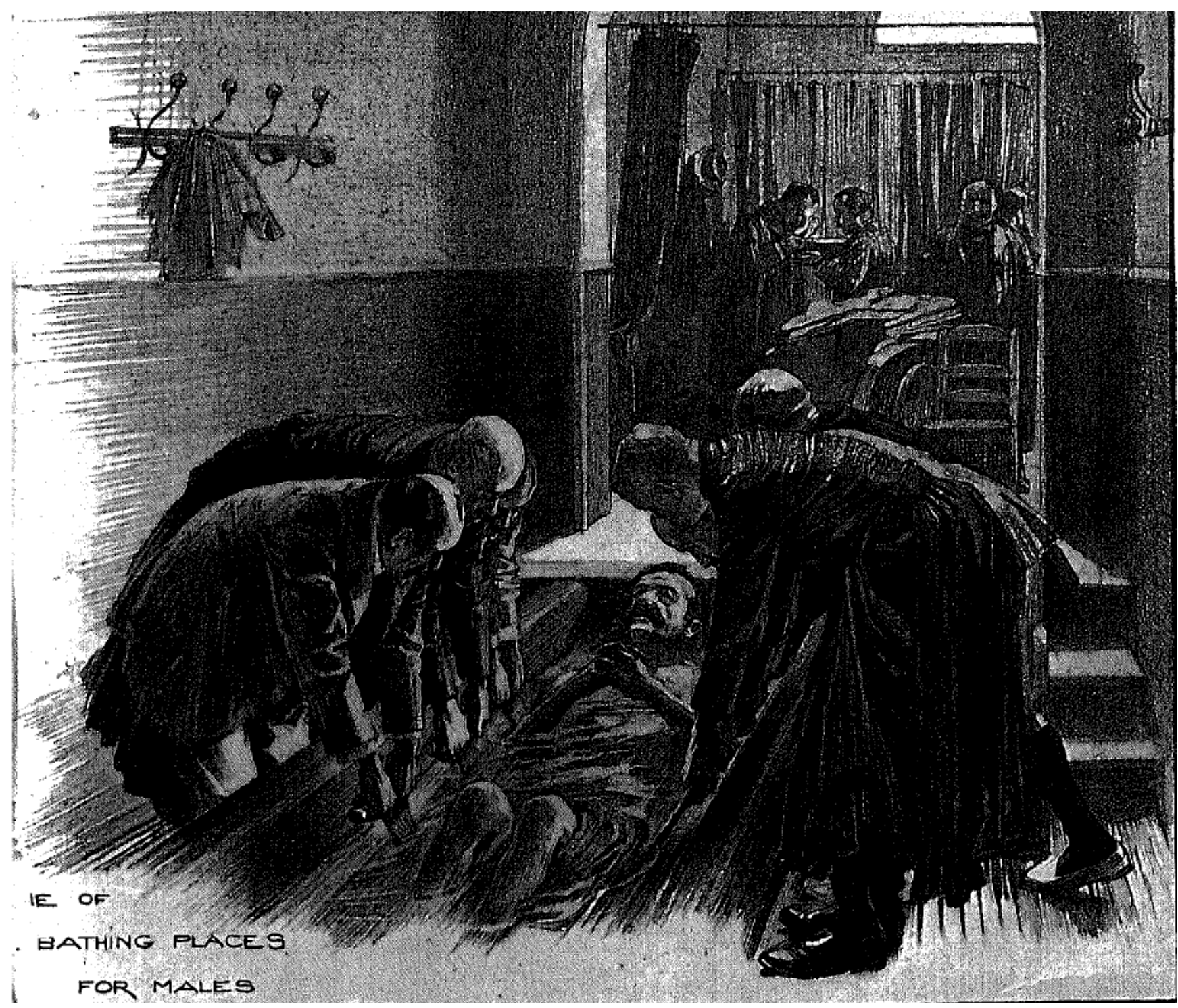

Figure 6: Pilgrims in the bathing house. Image taken from page 387 of "Pilgrims at Lourdes," The Graphic, September 23, 1905. 


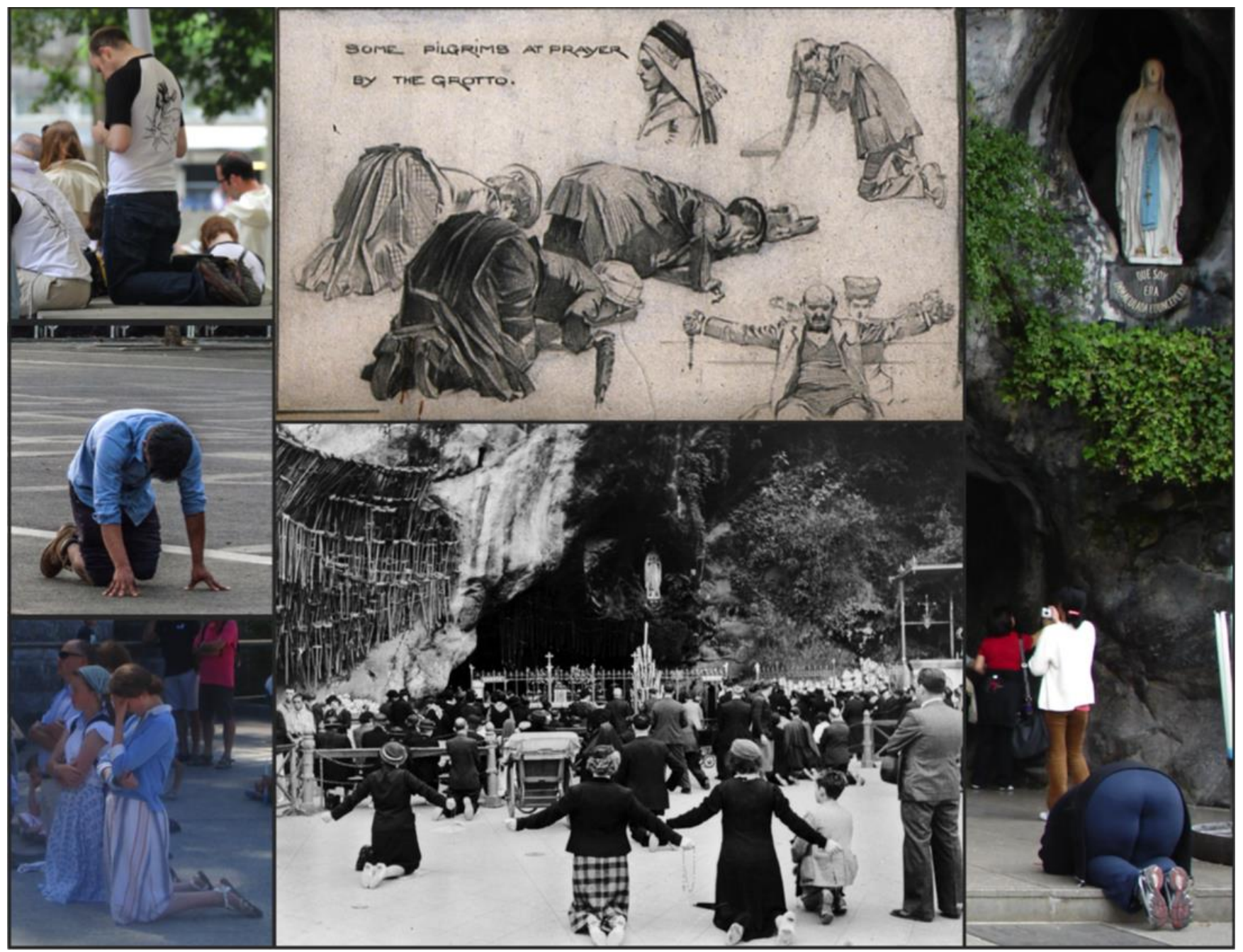

Figure 7: Pilgrims have been performing the same embodied acts of memory at the Lourdes Grotto (France) since the 1860s. From top left to bottom right: Lawrence OP, Dominican Youth praying the Rosary in Lourdes, August 6, 2013, Flickr accessed April 25, 2020, CC BY-NC-ND 2.0; R. Cleaver, Sheet of sketches showing the activities of pilgrims, September, 1905, Wellcome Collection accessed April 25, 2020, CC BY 4.0; David McLafferty, Lourdes Oct 2006, October 26, 2006, Flickr accessed April 25, 2020, CC BY-NC-ND 2.0; mariejirousek, Lourdes, August 29, 2018, Flickr accessed April 25, 2020, CC BY-NC-ND 2.0; Weekly Illustrated, Pilgrims kneeling before shrine of our Lady of Lourdes, September, 1937, Wellcome Collection accessed April 25, 2020, CC BY 4.0; Thomon, Pilgrims before the grotto of Massabielle in August 2019, August 23, 2019, Wikimedia accessed April 25, 2020, CC BY-SA 4.0. 


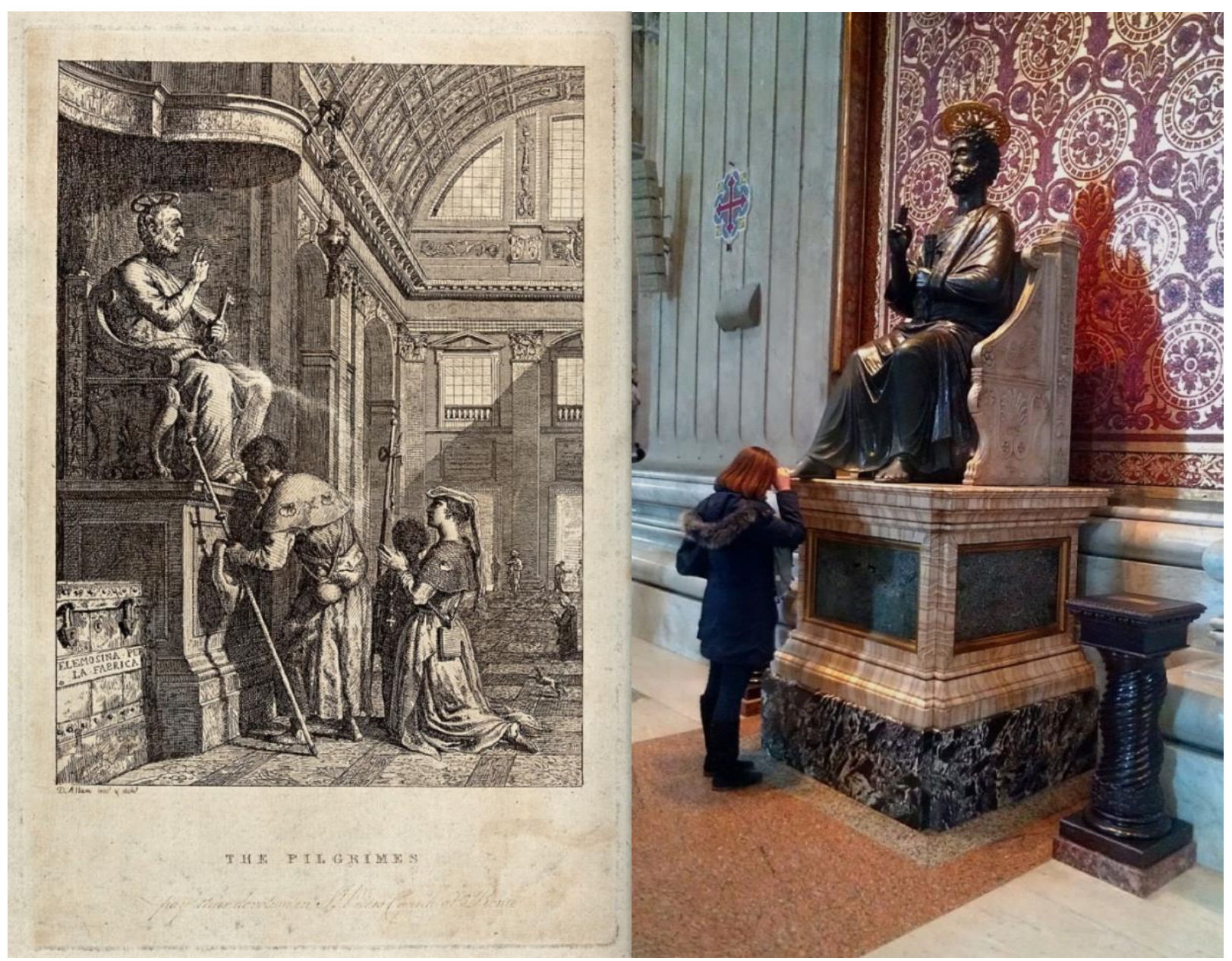

Figures 8 and 9: Pilgrims praying at the statue of St Peter in St Peter's Basilica in Rome. On the left: David Allan, Pilgrims in St Peter's in Rome pay devotion to the statue of St Peter, c. 1760, etching, $29.8 \times 19.3 \mathrm{~cm}$, Wellcome Collection, accessed April 24, 2020, https://wellcomecollection.org/works/u79wtjrc. On the right: Taken from Will van der Walt's, "The Foot of St Peter," Will Will Travel, accessed April 24, 2020, https://willwilltravel.wordpress.com/2017/07/18/the-foot-of-st-peter/. 


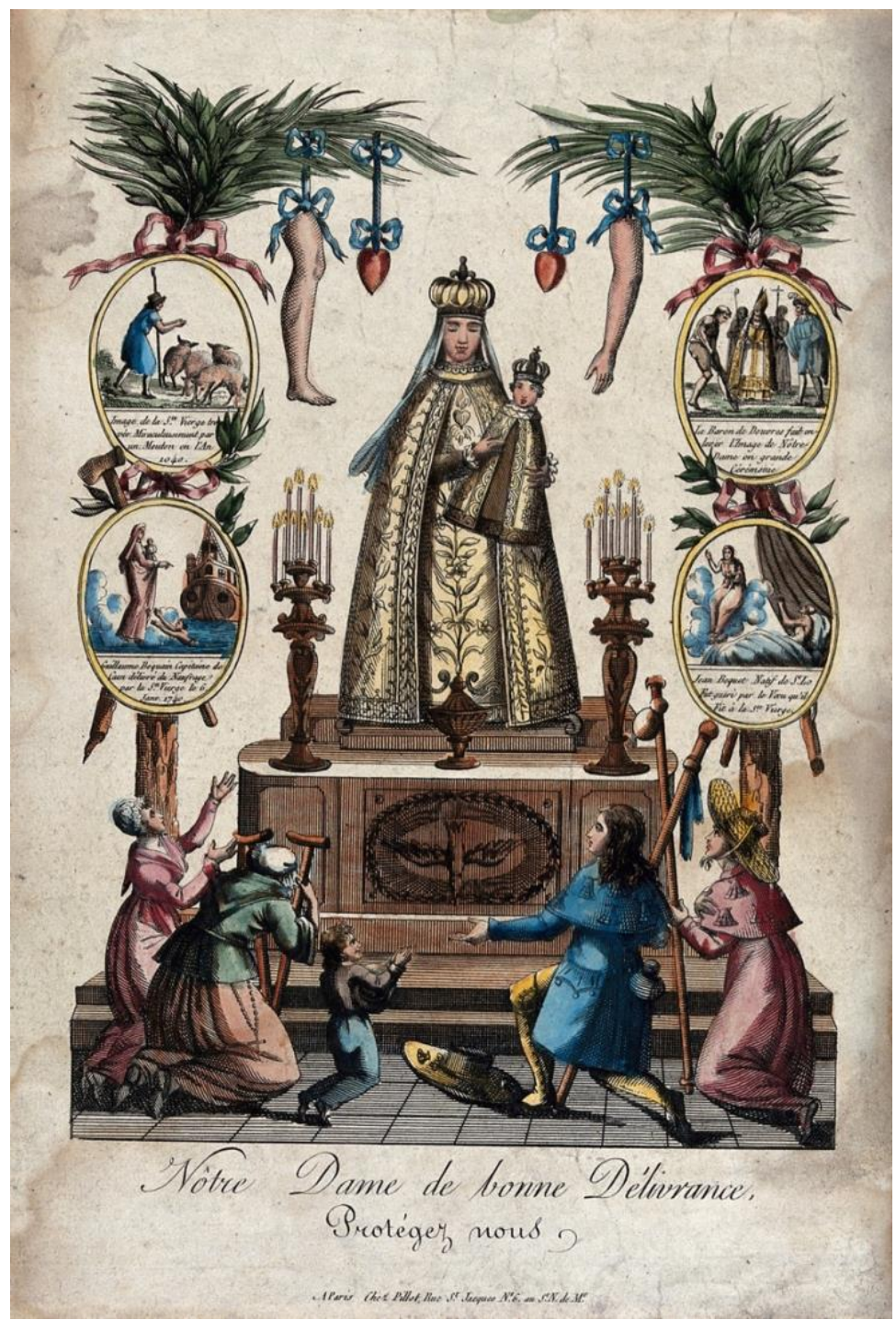

Figure 10: Alphonse Picard, The Virgin, Star of the Sea at Caen, venerated by pilgrims and sick people, c. $19^{\text {th }}$ century, Woodcut, 46.7 x $35.5 \mathrm{~cm}$, Wellcome Collection, accessed April 24, 2020, https://wellcomecollection.org/works/zj9pucze. 


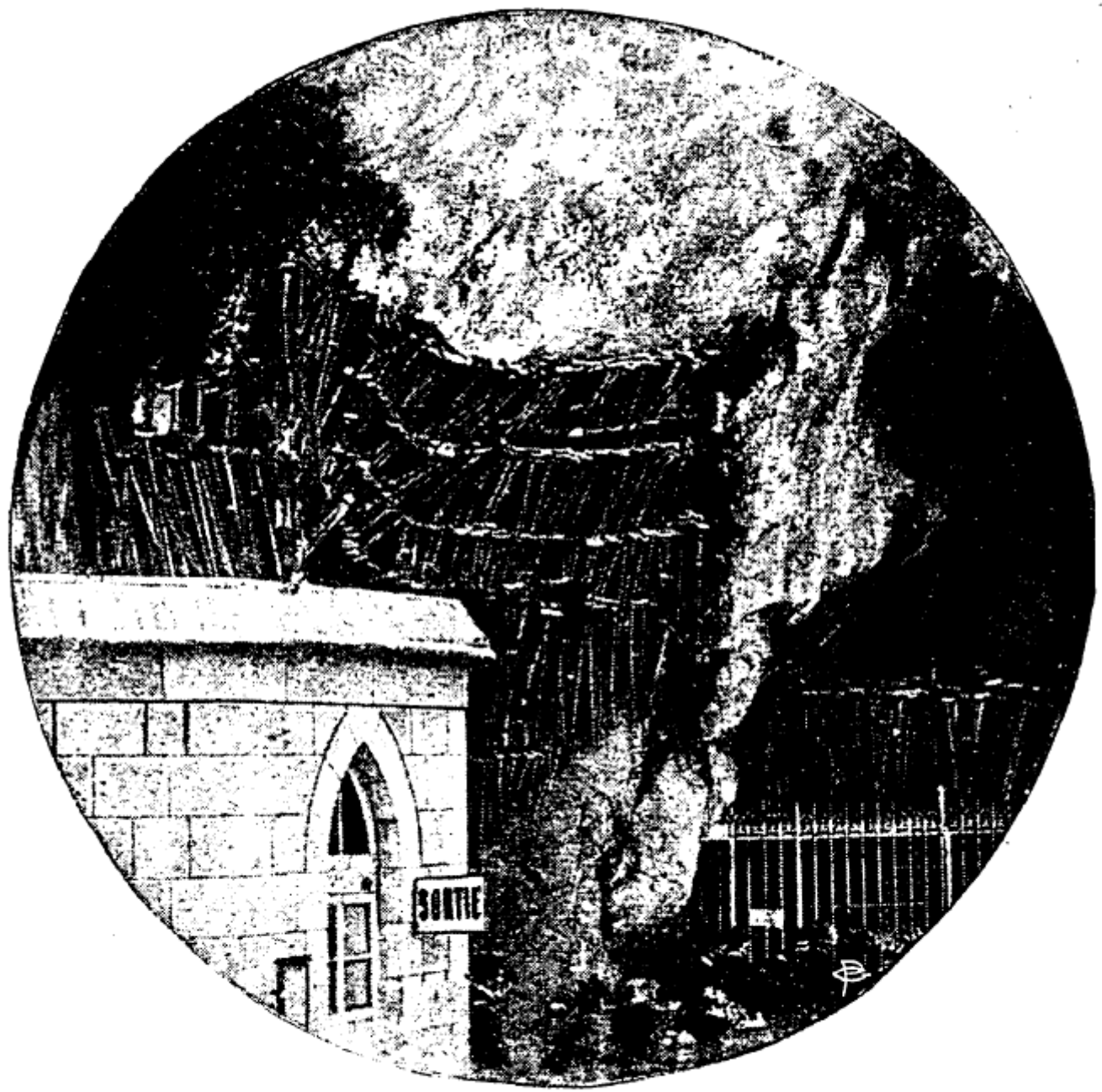

THESE CRUTCHES ARE SAID TO HAVE BEI.ONGED TO CRIPPLES WHO WERE CURED. NUMBERS ARE LEFT BEHIND BY PILGRIMS EVERY YEAR.

Figure 11: Crutches left behind in Lourdes. Taken from page 358 of "My pilgrimage to Lourdes," The London Magazine, November 1901. 


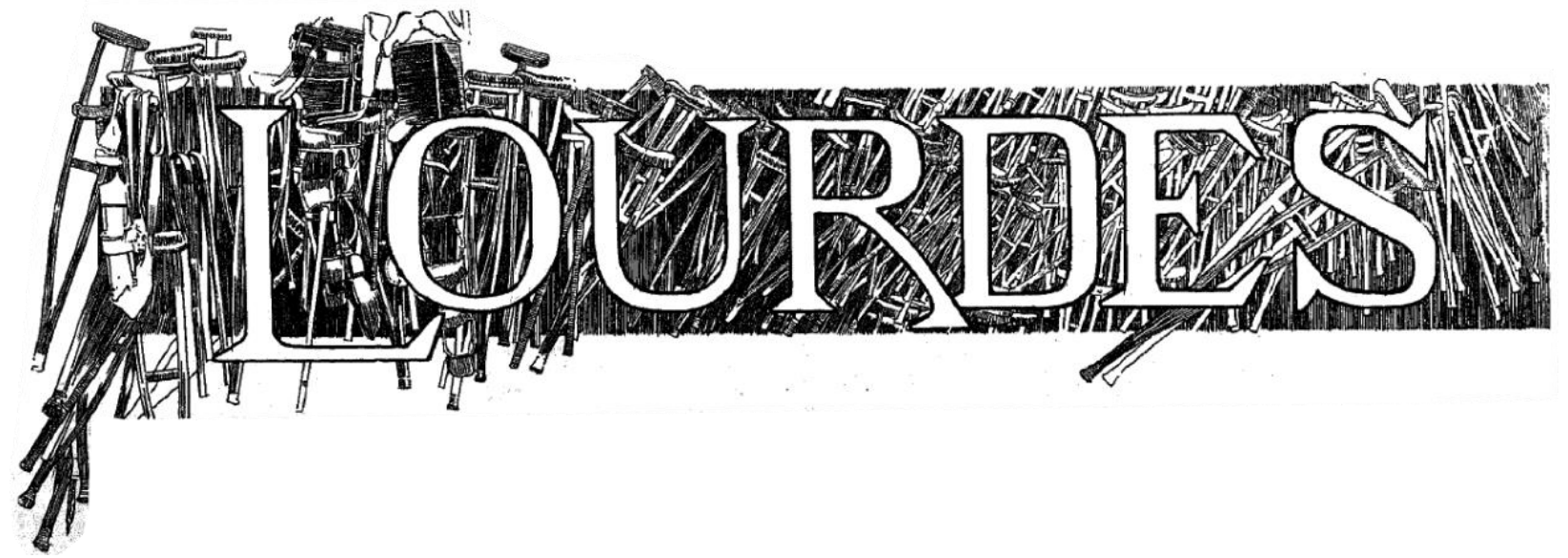

Figure 12: Title illustrating ex-votos for "Pilgrims at Lourdes," The Graphic, September 23, 1905.

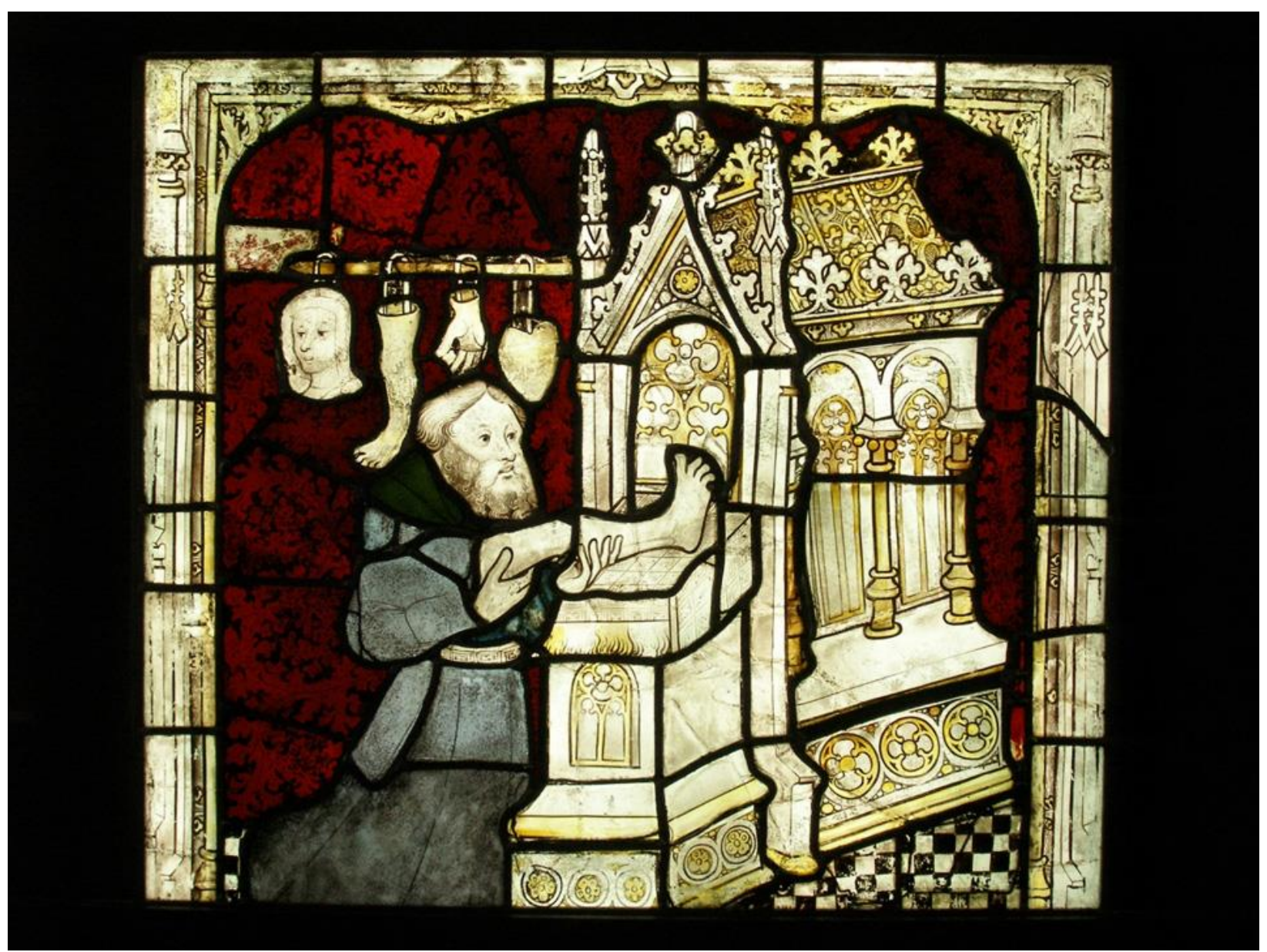

Figure 13: Pilgrim leaving an ex-voto at a pilgrimage shrine. Workshop of John Thornton Master Glazier, St William stained glass window in York Minster, c. 1415, Deangate, York, England. 


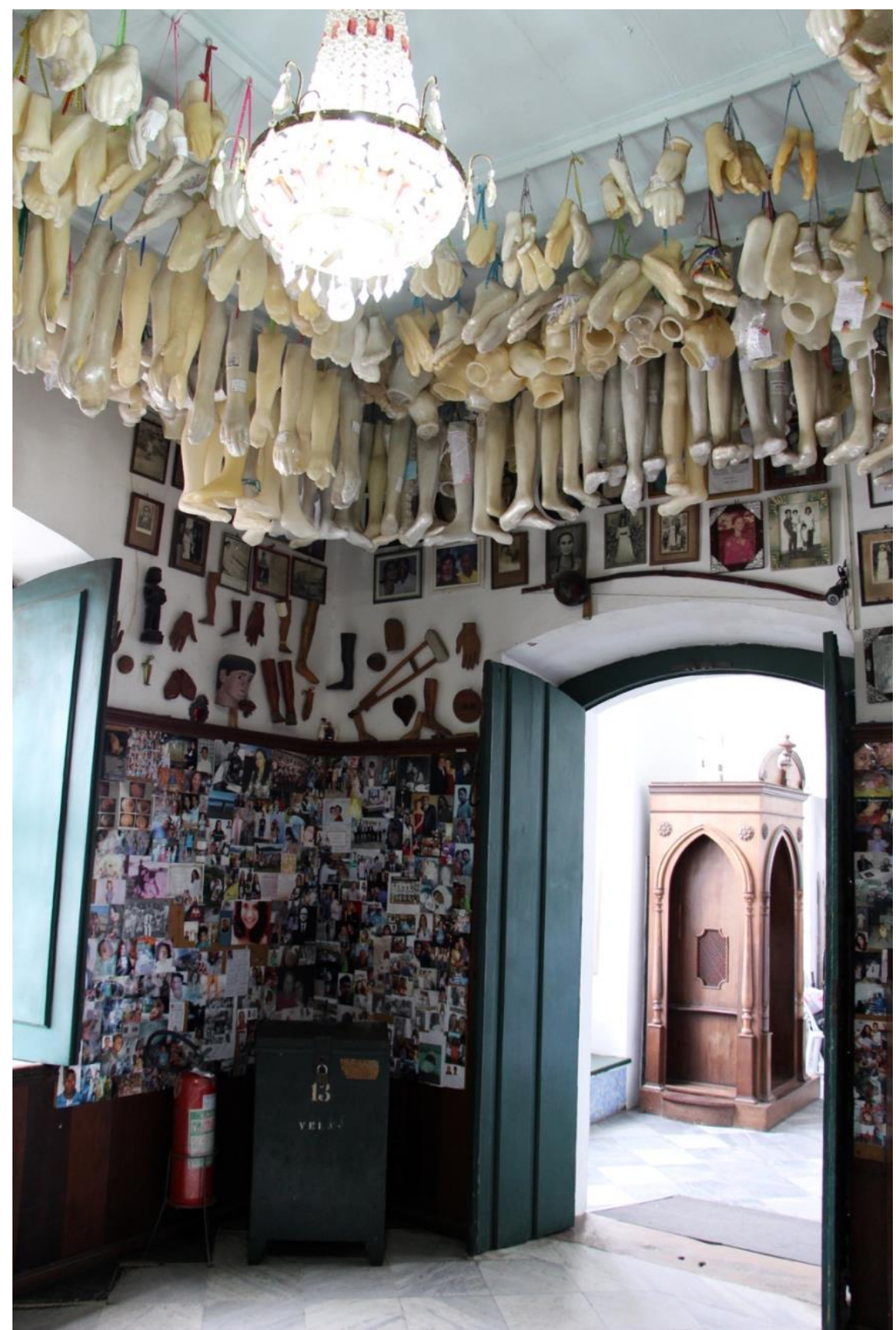

Figure 14: Pilgrims still leave ex-votos in the present day. Sailko, Salvador, chiesa di Nosso Senhor do Bonfim, int., stanza degli ex-voto, November 17, 2013, Igreja de Nosso Senhor do Bonfim, Salvador, Brazil, Wikimedia Commons, CC BY 3.0. 


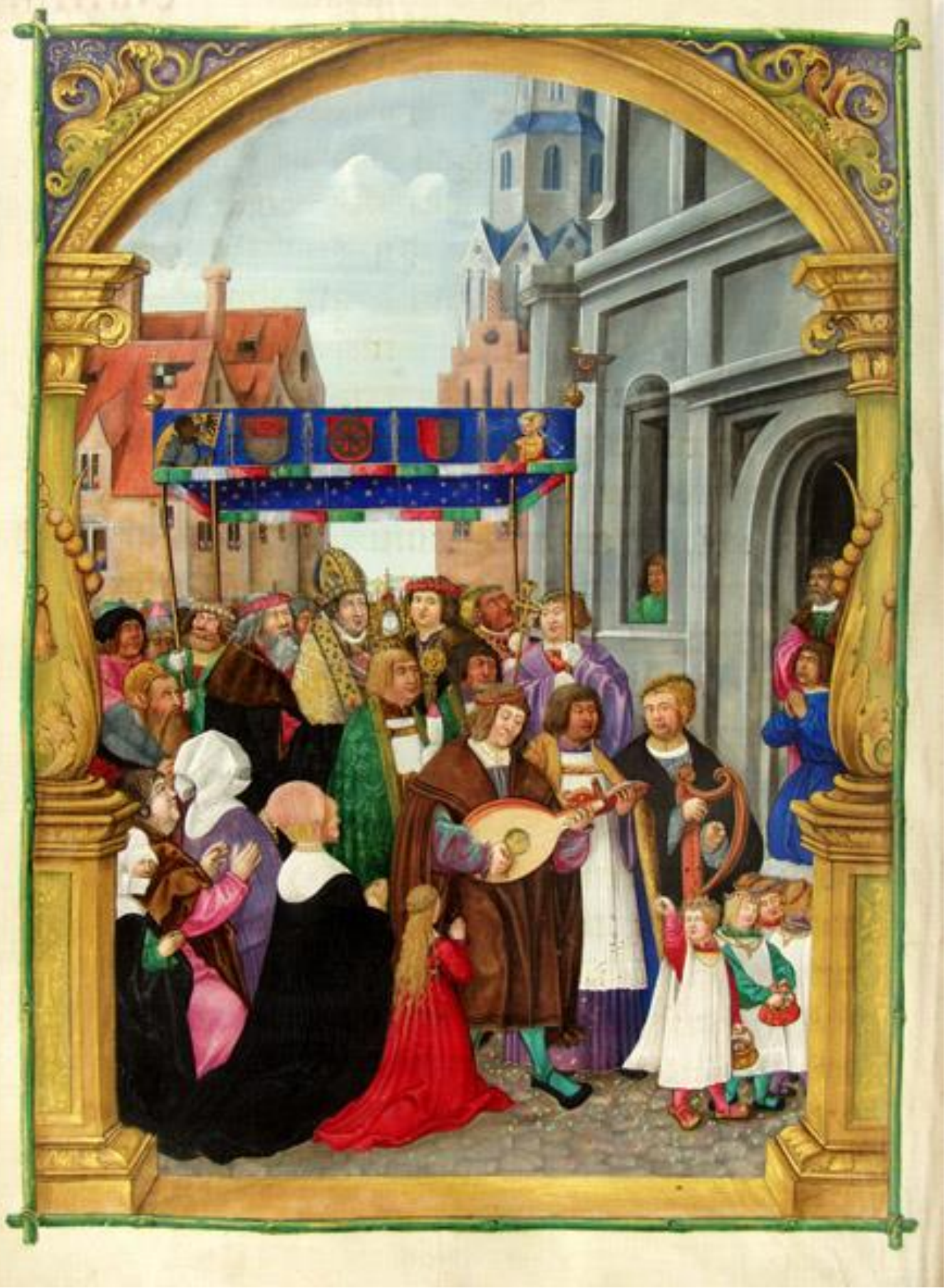

Figure 15: Corpus Christi Procession detail, Missale Hallense of Albrecht of Brandenburg, 1524, illumination on parchment, Ms.10, f.193 verso, Court Library Aschaffenburg, Germany. 


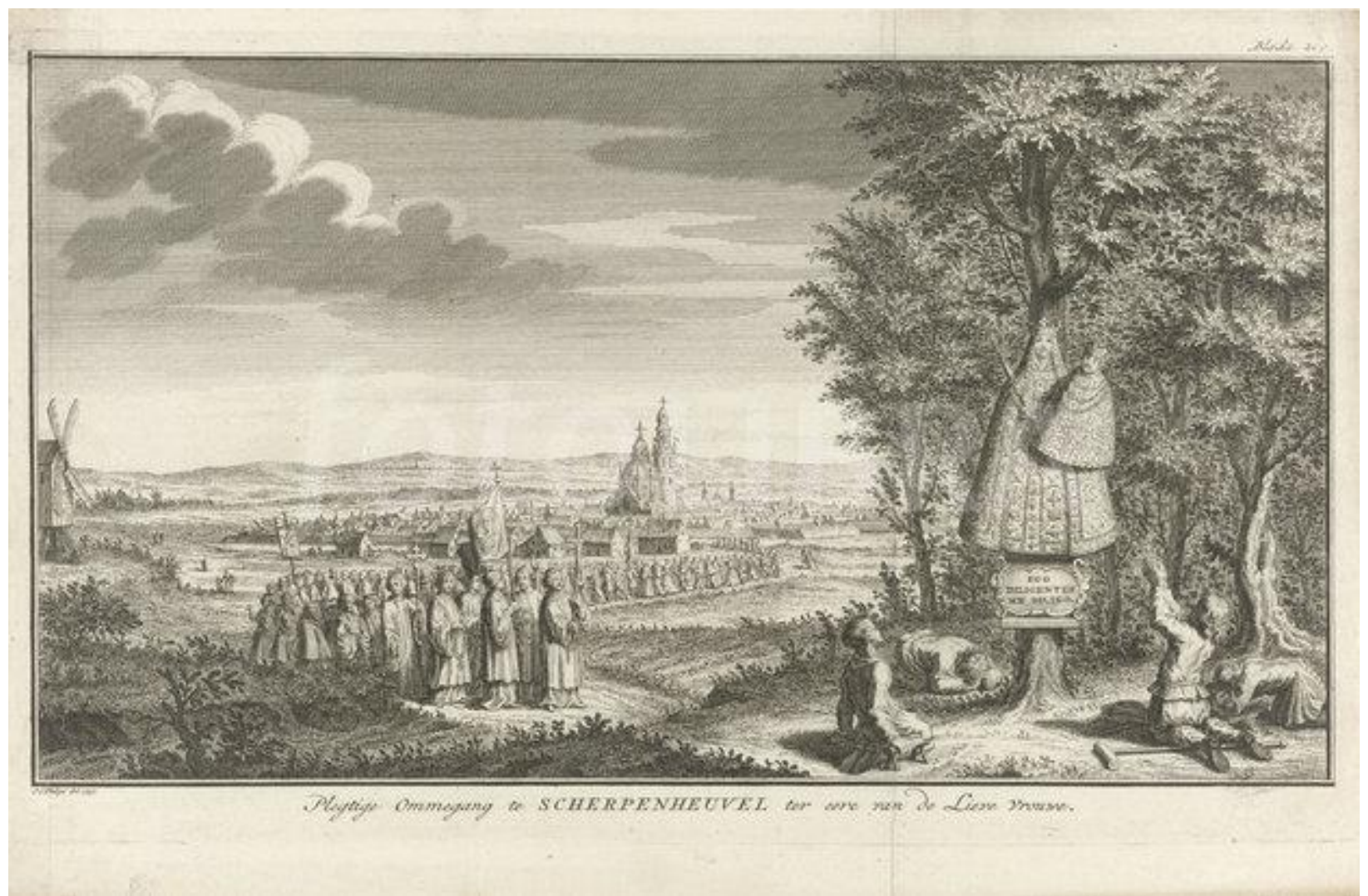

Figure 16: Jan Caspar Philips, Pilgrimage on the way to Our Lady of Scherpenheuvel, 1737, The Netherlands, 1737, engraving. 


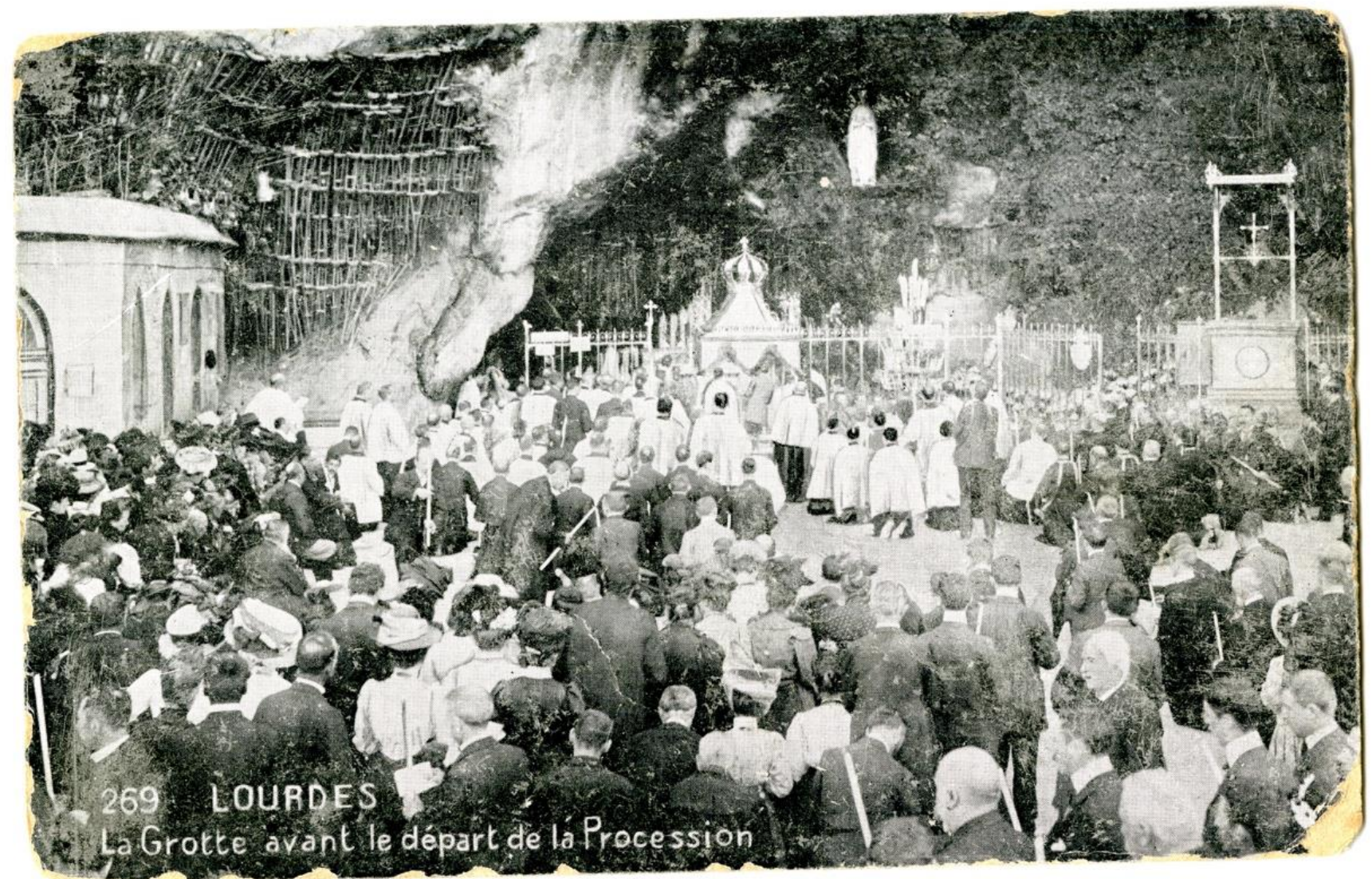

Figure 17: "The Grotto before the Procession," Lourdes postcard, 1900, Marian Postcard Collection, University of Dayton,

https://ecommons.udayton.edu/do/search/?q=pilgrimage\&start=0\&start_date $=01 \% 2 \mathrm{~F} 01 \% 2 \mathrm{~F} 183$ 0\&end_date $=12 \% 2 \mathrm{~F} 31 \% 2 \mathrm{~F} 1919 \&$ context $=3338972 \&$ sort $=$ score $\&$ facet $=$. 


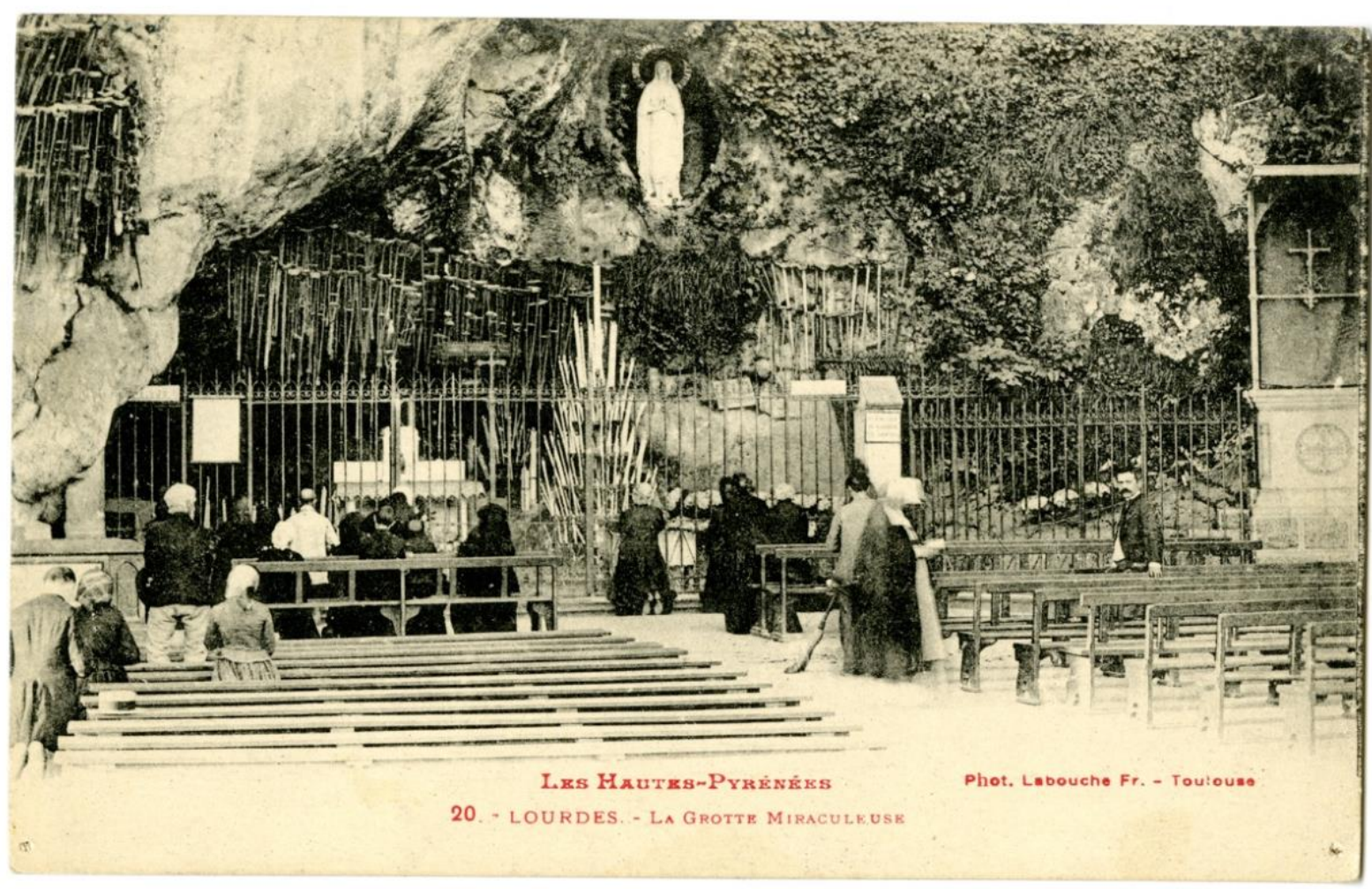

Figure 18: "Lourdes- The miraculous Grotto," Lourdes postcard, 1900, Marian Postcard Collection, University of Dayton,

https://ecommons.udayton.edu/do/search/?q=pilgrimage\&start=0\&start_date $=01 \% 2 \mathrm{~F} 01 \% 2 \mathrm{~F} 183$ 0\&end_date $=12 \% 2 \mathrm{~F} 31 \% 2 \mathrm{~F} 1919 \&$ context $=3338972 \&$ sort $=$ score $\&$ facet $=$. 


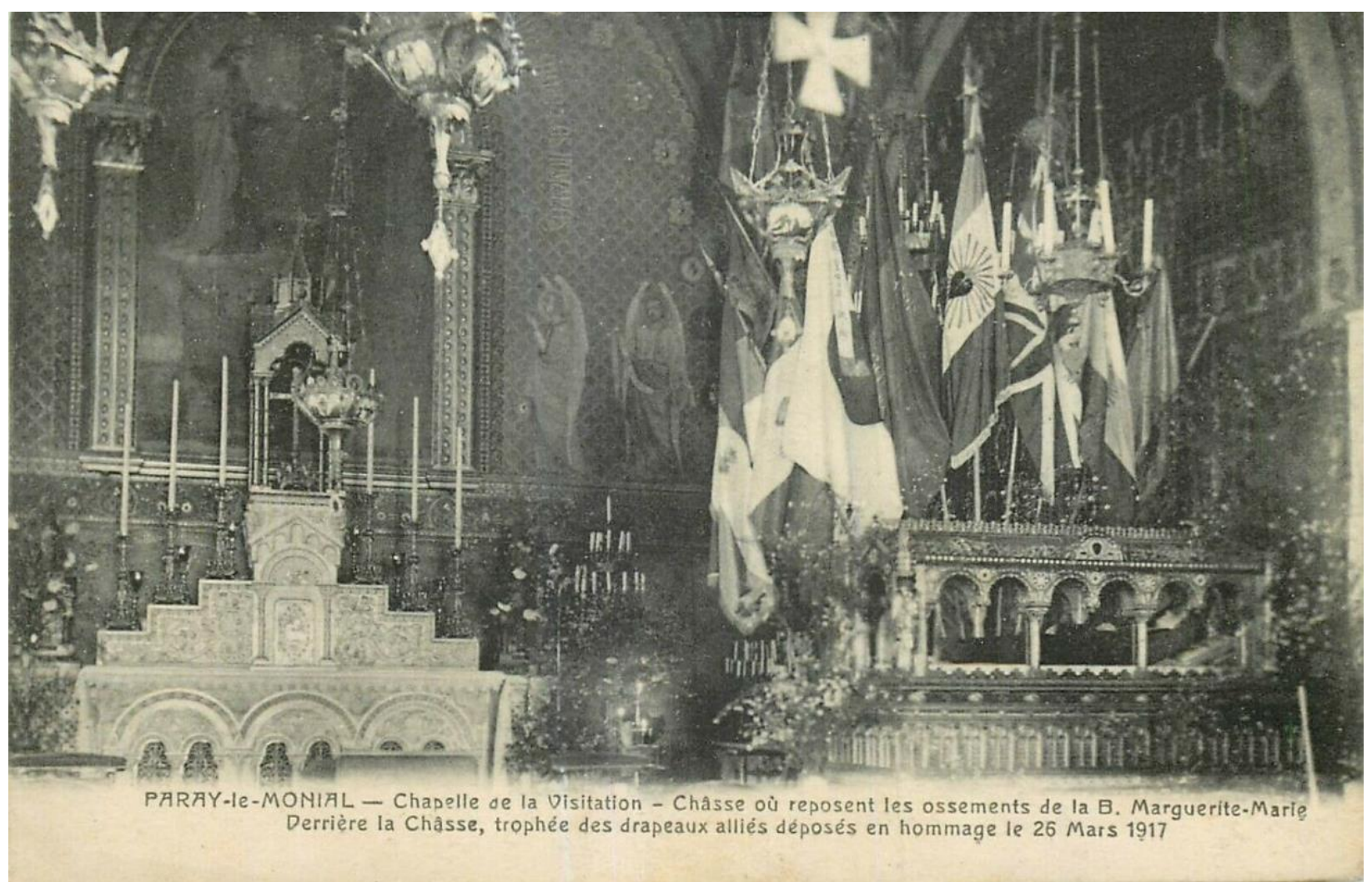

Figure 19: "Paray-le-Monial — Chapelle de la Visitation," Paray-le-Monial postcard, c. 1917, eBay, accessed July 25, 2020, https://www.ebay.fr/itm/PARAY-LE-MONIAL-chapelle-de-lavisitation/143608089663?hash=item216fb58c3f:g:KBEAAOSwlSZeZ8Fh. 


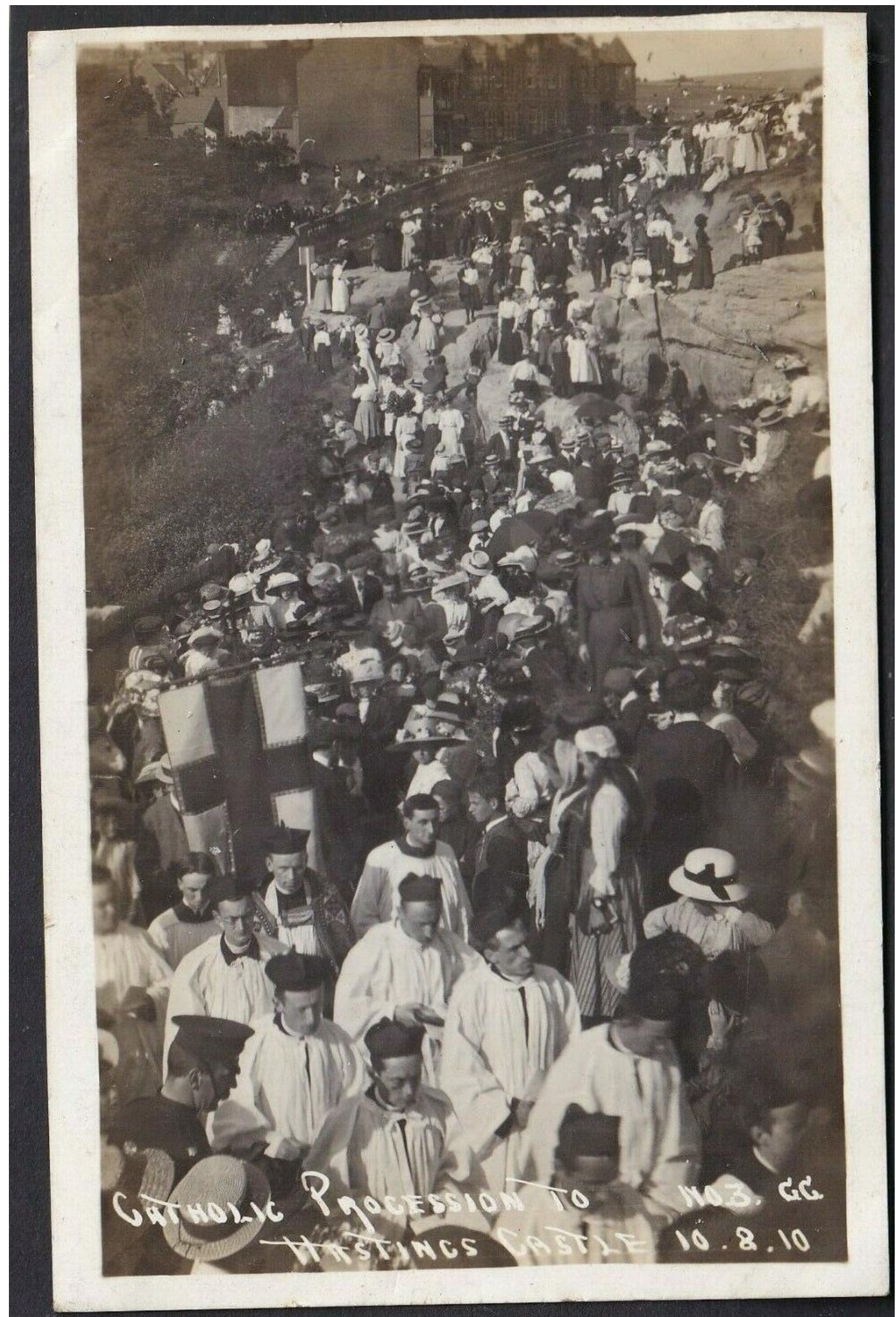

Figure 20: "Sussex - Catholic Procession to Hastings Castle," Sussex postcard, 1910, eBay, accessed July 25, 2020, https://www.ebay.fr/itm/Sussex-Catholic-Procession-to-Hastings-Castle1910-RP-Postcard/373123275819?hash=item56dfe15c2b:g:AZUAAOSw3ChfGEZz. 


\section{CONCLUSION}

As flames licked the stone spires of the Notre-Dame Cathedral on April 15, 2019, media outlets across the world agonized over the impending loss of an architectural marvel and a historical church. Yet, the media omitted a key aspect of the cathedral's significance - its role as a pilgrimage site.

Public historians need to seriously consider pilgrimage as an origin of the field.

Pilgrimage practices encouraged the public, in their role as pilgrims, to engage with, understand, and make use of the past in their contemporary lives. Pilgrimage was an outlet in which pilgrims actively engaged in the past and shaped historical narratives. On pilgrimage, pilgrims were concerned with questions of authenticity and continuity, comparing contemporary journeys to historic pilgrimage. Pilgrimage encouraged identity formation, as the faithful identified themselves both as particular to a national or parish group, as well as part of the universal Catholic Church. Those maintaining pilgrimage sites preserved historic structures, objects, manuscripts, and artwork. Lay people and clergymen founded new pilgrimage sites, as a way to memorialize a sacred event in tangible form. Archaeological digs resulted in the discovery of holy places, and pilgrims eagerly added them to their itineraries. Tour guides interpreted pilgrimage sites for the faithful, while at other times, pilgrims "read" the art on ancient walls. Pilgrims experienced a profound connection to the past and to pilgrims before them when venerating at shrines and sanctuaries. Pilgrimage allowed the devout to participate in intangible heritage through embodied acts and collective memory practices. The interpretation of pilgrimage sites made its way to the US, through educational lectures and pilgrimage literature. The faithful at home engaged with this shared Catholic heritage as they received souvenirs and 
postcards from loved ones abroad. Pilgrimage, like historical pageants, was a public history phenomenon at the turn of the twentieth century because it facilitated active engagement and a deep connection with the past.

Because of its grassroots nature, it has been overlooked by scholars of public history, but pilgrimage demands to be a subject of inquiry for public historians. In fact, pilgrimage practices have been ignored for far too long. The secularization inherent within the public history field has reduced religion as "other" and out of place, "a relic of the past, or a token of presumably less advanced civilizations."1 Museums have aestheticized sacred objects and architecture, valuing their form rather than their subject. Curators are finally realizing that religious objects can only be understood if their original religious context and meaning is recognized. ${ }^{2}$ Secularizing religious spaces and objects means that a certain portion of their story is not told - the public is not informed about a significant piece of their history and meaning.

In fact, exploring sacred spaces and objects as they are to be properly understood—as religious in nature - requires the public to put themselves in another's situation. They are encouraged to see how something could make sense within a certain context. Few historical objects and environments offer insights into "the worldviews and interior of people who lived long ago." 3 This exercise promotes a greater understanding of all those around us, as the public is prompted to imagine themselves within unfamiliar contexts and belief systems. Public historian

\footnotetext{
${ }^{1}$ Gretchen Buggeln, Crispin Paine, and S Brent Plate, eds. Religion in Museums: Global and Multidisciplinary Perspectives (New York and London: Bloomsbury Academic, 2017), xix.

${ }^{2}$ Paine, Religious Objects in Museums, 12; Hillary Kaell, "Museums, Expositions, and Religion in North America since the 19th Century," Oxford Research Encyclopedia of Religion (September 26, 2017): 4.

${ }^{3}$ Lauren F. Turek, "Religious History Objects in Museums" in Religion in Museums, in Religion in Museums: Global and Multidisciplinary Perspectives, Gretchen Buggeln, Crispin Paine, and S. Brent Plate, eds. (New York and London: Bloomsbury Academic, 2017), 58.
} 
Barbara Franco has found that people can connect to the universal theme of faith. ${ }^{4}$ Religion is not a compartmentalized element of human life but rather intersects with historical, archaeological, ethnographic, and artistic dimensions of society. ${ }^{5}$ Religion has played a significant role in the creation of the world and continues to do so today.

Religious spaces provide an opportunity for public engagement and interpretation. The Catholic Church has acknowledged this fact and published opinions regarding the relation between tourism and the church. The Church established a Pontifical Commission on Migration and Tourism in 1970, partly aimed at "providing religious assistance to all people who come within the area of tourism." ${ }^{6}$ Public officials have understood the importance of building bridges between religion and tourism. From 2002 to 2005, a German state developed local churches as tourist attractions by making them part of travel routes, incorporating one hundred and sixty-six village churches within twenty-four routes. The project was sponsored by the European Union and provided road signs and pocket guides for visitors. ${ }^{7}$ In 1987, the Council of Europe declared the Camino de Santiago, a well-known pilgrimage route, as a Cultural Route in order "to foster awareness that European civilization as a whole has one of its common roots in the pilgrimage route, which is an historical example of encounter and sharing among European cultures." 8 Then in 1993, UNESCO inscribed the Camino in its World Heritage List. ${ }^{9}$ The Via Francigena, an

\footnotetext{
${ }^{4}$ Barbara Franco, "Issues in Historical Interpretation: Why Interpreting Religion Is So Difficult," in Interpreting Religion at Museums and Historic Sites, Gretchen Buggeln and Barbara Franco, eds. (Lanham: Rowman and Littlefield, 2018).

5 Paine, Religious Objects in Museums, 109.

${ }^{6}$ Stausberg, Religion and Tourism, 39-40; Roman Curia, Pontifical Council for the Pastoral Care of Migrants and Itinerant People, Vatican.va, accessed October 20, 2020,

http://www.vatican.va/roman_curia/pontifical_councils/migrants/documents/rc_pc_migrants_doc_19960520_profile _en.html.

${ }^{\overline{7}}$ Stausberg, Religion and Tourism, 43.

${ }^{8}$ Marion Bowman and Tiina Sepp, "Caminoisation and Cathedrals: Replication, the Heritagisation of Religion, and the Spiritualisation of Heritage,” Religion 49 (March 2019): 77.

${ }^{9}$ Stausberg, Religion and Tourism, 60.
} 
ancient pilgrimage route, became a Council of Europe Cultural Route in 1994, and the Council of Europe declared the Via Sancti Martini, a path linking sites connected to the life of St Martin, a European Cultural Itinerary in $2005 .{ }^{10}$ The routes include ecological, cultural, and historical dimensions that could be of interest to both the pilgrim and the tourist.

\section{A Call to Public Historians}

Public historians have a duty to recognize pilgrimage practices as an outlet for public history. Pilgrimage is "as popular as ever," attracting more devout participants to pilgrimage sites than ever before, across cultures and religious traditions. ${ }^{11}$ Religious pilgrimage is a phenomenon that engages millions of pilgrims a year and will continue to attract the faithful in the future. Pilgrimage centers even draw a large number of visitors who do not travel for religious motives. ${ }^{12}$ Public historians need to collaborate with religious groups, as the partnership is mutually beneficial. Religiously affiliated historic sites welcome outsiders who are curious to learn about an unfamiliar tradition. Public historians can lend their expertise to the development of the interpretation and preservation of religious sites, adding nuanced historical context to these holy places. Religious sites can be developed into "multi-use sites" in order to cater to both the religious visitor and the tourist. ${ }^{13}$ The incorporation of highly trained heritage guides would benefit visitors but also the local community, as visitors would be prepared and instructed to be more culturally sensitive and ethical. ${ }^{14}$ A collaboration with public historians will make these sites more accessible and visible, exposing the public to important histories that have been overlooked.

\footnotetext{
${ }^{10}$ Bowman and Sepp, "Caminoisation and Cathedrals," 81-82.

${ }^{11}$ Stausberg, Religion and Tourism, 55.

12 Ibid., 55.

13 Ibid., 90.

${ }^{14}$ Sophia Labadi and Colin Long, eds., Heritage and Globalisation (New York and London: Routledge, 2010$), 138$.
} 
There have been some cases of collaboration between public history professionals and religious groups. In the twentieth century, the Catholic Church joined forces with the state preservation groups and the National Park service to transform the San Antonio missions into aesthetically pleasing attractions. ${ }^{15}$ Although initially resistant, the professional museum community has begun to work with Indigenous populations in order to incorporate Indigenous curatorial methods when caring for Indigenous objects. The Co-curation allows for an exchange of information, knowledge, expertise, and the development of new museological practices. ${ }^{16}$ The historic Arch Street Meeting House, a religious site used and still in use by the Quakers, provides guided tours by heritage professionals. The site's heritage staff held listening sessions and sent out anonymous surveys in order to develop their interpretation. For questions regarding religious practice, guides direct visitors to a practicing Quaker who can answer them appropriately. ${ }^{17}$ The Kirtland Temple, the first Mormon temple, attracts over thirty thousand visitors a year. The reasons for their visits range from religious considerations, to architectural interest, to fascination with history. In order to cater to both religious and secular motivations, the staff opened a visitor center that serves both audiences. Only ministers trained in spiritual direction lead pilgrims at the Spiritual Formation Center, and historians consult on any educational programs offered by the staff. $^{18}$

At certain sites, the National Park service has interpreted religious history. In 1980, the National Park service established the Kalaupapa National Historic Park in Hawaii. When leprosy was introduced to the Hawaiian Islands, King Kamehameha V sent all those infected to the

\footnotetext{
${ }^{15}$ Bremer, Blessed with Tourists, 69.

${ }^{16}$ Christina Kreps, "Indigenous Curation, Museums, and Intangible Cultural Heritage," in Safeguarding Intangible Heritage, Natsuko Akagawa and Laurajane Smith, eds. (London: Routledge, 2018), 199.

${ }^{17}$ Gretchen Buggeln and Barbara Franco, eds., Interpreting Religion at Museums and Historic Sites (Lanham: Rowman \& Littlefield, 2018), 5-6.

18 Ibid., 27-29.
} 
isolated Kalaupapa peninsula on the island of Molokai. The locale now serves as place for education and contemplation. At the site, the National Park service interprets the lives of the Hawaiians who settled on the land before the establishment of the leper colony, the lives of the patients who lived in the leper colony, and the lives of the helpers who came to care for those afflicted. Among the helpers were Catholics such as Father Damien, now a canonized saint, Mother Marianne Cope, the nuns from the Sisters of St Francis, and Brother Joseph Dutton. Another helper was Jonathan Napela, a member of the Church of Jesus Christ of Latter Day Saints. The site presents an interesting example of how various groups - the National Park service, the Catholic Church, and the Church of Jesus Christ of Latter Day Saints—work together to interpret many different histories, both religious and secular in nature. ${ }^{19}$ Faith played an important role in the lives of the patients at Kalaupapa, so the discussion of religion is essential to presenting visitors with a complete interpretation of the site.

The general public desires to experience the past through heritage tourism and this includes visiting religious sites. For most travelers to Europe, religious architecture is an essential component of their itineraries, particularly pre-modern churches steeped in Church history. Notre-Dame Cathedral in Paris was noted as the most popular attraction in Europe, the Sagrada Familia in Barcelona was reported as Spain's most visited monument, and five out of the ten most visited historic sites in the United Kingdom were cathedrals. ${ }^{20}$ Catholic pilgrimage destinations attract millions of visitors every year. Lourdes in France brings in five million visitors annually and houses more hotels than any French destination other than Paris. ${ }^{21}$ Fátima

\footnotetext{
${ }^{19}$ See "Kalaupapa," National Park Service, accessed October 15, 2020, https://www.nps.gov/kala/learn/historyculture/na-kokua.htm.

${ }^{20}$ Stausberg, Religion and Tourism, 79.

${ }^{21}$ Gary Vikan, From the Holy Land to Graceland: Sacred People, Places and Things in Our Lives (Washington, DC: The AAM Press, 2012), 76.
} 
in Portugal attracts four million visitors, Santiago in Spain even more, and Nossa Senhora

Aparecida in Brazil draws more than eight million. ${ }^{22}$ St Joseph's Oratory in Montreal hosts two and a half million visitors annually, and St Anne de Beaupré in Quebec accommodates close to a million. ${ }^{23}$ These sites are among the most visited tourist destinations of their respective countries. Pilgrimage events also attract tourists, such as the Hopping Procession of Echternach that brings in thirteen thousand visitors annually. ${ }^{24}$ If the public is visiting these sites, public historians need to use these spaces as opportunities of encounter and historical education.

Public historians work with state and local governments to create historical programming to stimulate local economies and the same can be done with religious sites. Rural churches in Europe have become destinations of day trips, bringing valuable resources to rural economies. ${ }^{25}$ The interpretation of churches and pilgrimage sites within the United States could provide similar revenue to rural communities. Typically, public historians are not invited into locales, but rather they insert themselves to advocate for the interpretation of the past. It may be time for public historians to take the initiative to help communities preserve and interpret their religious spaces. Preservation specialists could collaborate with religious communities to preserve their historic structures and teach the communities preventive preservation techniques. ${ }^{26}$ With the help of architectural historians, art historians, religious studies scholars, and anthropologists, public

\footnotetext{
${ }^{22}$ Stausberg, Religion and Tourism, 57.

${ }^{23}$ Martin Geoffroy and Jean-Guy Vaillancourt, "The New Pilgrimage-Return to Tradition or Adaptation to Modernity? The Case of Saint Joseph's Oratory, Montréal" in On the Road to Being There: Studies in Pilgrimage and Tourism in Late Modernity, William H. Swatos Jr, ed. (Leiden; Brill, 2006), 255; Emma Anderson, "Pilgrims' Presence: Catholic Continuity in Quebec" in Everyday Sacred: Religion in Contemporary Quebec, Hillary Kaell, ed. (Montreal: McGill-Queen's University Press, 2017), 162.

24 "Hopping Procession of Echternach," UNESCO, accessed September 30, 2020, https://ich.unesco.org/en/RL/hopping-procession-of-echternach-00392.

${ }^{25}$ Stausberg, Religion and Tourism, 79.

${ }^{26}$ If the community is seeking to be listed on a state register of historic places, the restrictions surrounding the preservation of historic landmarks may make this sort of intervention difficult. However, if communities are interested in maintaining their historic structures without the help of the state historic preservation office, it may be an option.
} 
historians could interpret church structures and sacred spaces, presenting visitors with analyses of the architecture, artwork, and material culture, as well as the religious practices and religious history associated with the site. Public historians could establish cultural routes linking historic rural churches, creating new heritage destinations for visitors in the region. These developments would give local inhabitants pride of place, transforming what used to be an old building on the skyline into a valuable piece of local history.

At times, Catholic dioceses relegate sacred spaces to profane use. This means that a church building is no longer used for Catholic liturgical worship, so it is used for secular purposes or sold. Both because of the decrease of Catholic parishioners and the clerical sexual abuse crisis, Catholic dioceses around the United States have been deconsecrating and selling historic properties. Some of the properties are adaptively reused to serve new communities, such as the former St Gerard Roman Catholic Church in Buffalo, New York that was sold to be converted into a mosque or former St Margaret of Scotland Church in Waterbury, Connecticut that was sold to the Brass City Charter School and converted into an auditorium. ${ }^{27}$ However, many of the historic churches are sold to developers and razed, such as former St John Cantius Church in Northampton, Massachusetts and former Mary Help of Christians Church in New York City. ${ }^{28}$ These historic religious structures are worth saving because of their architectural beauty, but also because of the social ties the local community forms within the ancient eaves.

\footnotetext{
${ }^{27}$ Lamonica Peters, "Vacant Catholic Church Will Become Mosque on Buffalo's East Side," Spectrum News, February 4, 2017, https://spectrumlocalnews.com/nys/buffalo/news/2017/02/3/st--gerards--catholic--church-buffalo--east-delevan--father-mazur--muslim--mosque?fbclid=IwAR2SW4hsnSdbS97SSY7EEaJ3sm6t1O7mUP94z3s-cKkoeQ5sXsBWXD-pV8; Ed Stannard, "Pain Mingles with Acceptance as Closed Catholic Churches Are Sold, ” New Haven Register, January 21, 2019, https://www.nhregister.com/news/article/Painmingles-with-acceptance-as-closed-Catholic-13546893.php\#item-85307-tbla-3.

${ }^{28}$ Jim Kinney, "Holyoke Developer Buys St. John Cantius in Northampton for \$1.6M; 23 Townhouses Planned," Mass Live, April 2, 2020, https://www.masslive.com/business/2020/04/holyoke-developer-buys-st-john-cantius-innorthampton-for-nearly-3m-23-townhouses-planned.html. Amy Zimmer, "A Dozen Church Properties Deconsecrated by Archdiocese for Potential Sale," DNA Info, July 26, 2017, https://www.dnainfo.com/newyork/20170726/east-village/catholic-church-archdiocese-real-estate-sales/.
} 
The closing and destruction of a church means its former parishioners will no longer be able to visit or worship in the sanctuary where they were married, where their children were baptized, or where their parents were laid to rest. A parishioner described the deconsecration of her local parish as "just like when you lose a close family member." ${ }^{29}$ Former church buildings are continually on the market, and public historians should take the opportunity to use them to interpret religious history, ethnic history, immigration history, and social history.

As beneficial as it is to interpret religious and pilgrimage sites, it is important to remember that the primary duty and responsibilities the public historian would have in these sacred spaces are towards an audience with a specific religious belief. In the majority of cases, religious groups ultimately have control of the religious site, and while non-practicing visitors should be welcomed into the space, it would be imperative that pilgrims are not pushed out. Shared authority, the "conviction that historians do not own history" as it is "a sort of public domain," would allow public historians to share their expertise while also taking care to listen to the desires and concerns of the local religious community. ${ }^{30}$ It would be the most pure form of shared authority, because in this case public historians would not be sharing authority with religious groups but rather religious groups would choose to share authority with outsiders.

Public historians would have to understand how churches use their history and be willing to work within those parameters. Sacred spaces are often used for faith building. There are some narratives, that although interesting and important, are not conducive to that. It does not mean that the narratives cannot be told in another space or other places, in fact, they should. But public historians, outsiders in this case, have to understand the framework within which they are

\footnotetext{
${ }^{29}$ Stannard, "Pain Mingles with Acceptance as Closed Catholic Churches Are Sold." The National Council on Public History held a "On the Fly" discussion on this topic at their 2019 conference.

${ }^{30}$ Cauvin, Public History, 14.
} 
operating. It is the willingness to work within the framework that will build trust between public historians and communities of faith. It is not about silencing voices, but alternatively discerning the appropriate space for the interpretation of each individual narrative. Although the collaboration between religious groups and public history professionals may not be clear-cut or simple, it is a valuable partnership that can add nuance, complexity, and sensuality to historic interpretations of religious spaces. The alliance is sure to bear fruit for the pilgrim as well as the tourist. 


\section{EpILOGUE}

On an afternoon in late April, I interviewed Tony Dilulio, the programs director at the National Shrine of Saint Elizabeth Ann Seton in Emmitsburg, Maryland. The shrine consists of a basilica, a museum, a visitor's center, several historic structures including a nineteenth century schoolhouse, and a cemetery. I asked him questions about the history of the shrine, the visitors it attracts, and the shrine's interpretation and programming.

“The shrine was not always a shrine because Mother Seton wasn’t always a saint," Dilulio explained to me. What is now the shrine started out as a provincial for the Province of the Daughters of Charity, a religious order. In the late 1960s, then blessed Elizabeth Ann Seton's body was reinterred under the altar of the basilica, transforming the space into a shrine. When Elizabeth Ann Seton was canonized as a saint in 1975, pilgrims steadily streamed to the expansive sanctuary. By 2011 Seton Heritage Ministries, a mainly lay-run organization, acquired management of the shrine. Their mission statement is "to promote the life and legacy of St Elizabeth Ann Seton as a source of inspiration and encouragement for all people." The shrine attracts both Catholics and non-Catholics. With a total of sixty-two thousand visitors last year, the primary motivation was religious. However, Dilulio noted, "We have a number of programs that are more of a history draw and so that, I think, increased our number of non-Catholics." He guessed that that around ten to fifteen percent of visitors are non-Catholic. "More of the people who.... are looking at the visitor's center are, I wouldn't say necessarily religiously motivated. I don't know if I would say the majority, but I would say a much bigger chunk who enter.... the visitor's center, are kind of just looking for something interesting to do." 
When asked to expand on the nature of the work conducted at the shrine, Dilulio

explained,

We are not only a site for Catholics or for religious history. We are a site for religious history, and you might even say we're making religious history. We're trying to do new great work in the Church today, but that does not mean everything we're doing is strictly for people that are motivated by religion. So, for instance....our education programs are much more broad based and have a much broader appeal in the sense that we have some unique things, just if you look at us strictly as a museum or historic site. One is that we have a nineteenth century school that is set up, you can see it, and we actually are working [with] living historians who are [acting as] school girls, to be able to present and give people a taste, an immersive experience, of what a school was like in the nineteenth century. There are very few places that are doing that with a school in the United States today....It was a religious school, so we're going to have the sisters there, living historians dressed up as sisters, and they will show the girls doing their routine which included religious stuff....we make it a point in our education just to tell the facts. Like here's what happened with Elizabeth Seton, here's what happened with her sisters, here's what happened at this site. And of course, that includes religious history because that's what was going on.

The director asserted that visitors are interested in religious history.

We've found people from all walks of life are very interested in religious history because it's what motivated people to do some things that otherwise would be considered very wild. Like why would Mother Seton have moved out to the mountains and started a school. That's crazy. Why would you even move to Baltimore, you know? She never would have if it were not for her religion....understanding the religious motivation is really key to understanding just why did this happen.....and it doesn't mean somebody has to know and adopt the belief of the subject they're learning about, but they do have to at least understand what it is.

Tour guides at the shrine make sure to remove specialized vocabulary from their

interpretations. "We try to make our language lingo-free as much as possible. There's a bunch of Catholic lingo that a lot of people, even Catholics, don't know what it means, and that's okay. We shouldn't use that word." Additionally, guides give third-person interpretations. "We don't walk around and point to things and say 'We believe that Jesus died on the cross to save our sins.' We'll say something like, 'Catholics believe this' or 'the custom among many believing Catholics is such and such."' Dilulio gave his reasoning for interpreting the shrine in this way. 
We try to talk about it in third-person and our rationale for that is that, we have a preferential option for the new and occasional visitor. And that's sort of our key, the new and occasional visitor. What is their perspective and what are their concerns, what do they need to know to be comfortable at the Shrine to understand and not feel like they're out of place. As a religious institute it's really easy to make somebody feel like 'oh I'm not supposed to be here' or 'I'm out of place' or 'I'm not one of these people.' So even though we may know that we only have Catholics on tour, we don't know exactly what they know. So we just always default to that third-person language talking about it.... We don't want to put people off. We want people to feel welcome, we want them to feel wanted, we don't want them to feel awkward.... It accommodates people who aren't Catholic because they don't feel awkward and we can be hospitable .... I think people appreciate that of all stripes.

When asked why Catholics should visit the shrine, Dilulio answered,

Catholics should visit this site because they should know and love Mother Seton more than they do now.... She is such a great model for how to be Catholic in America. And there's a reason that the Church, guided by the Holy Spirit, picked her as the first person born in America to be named a saint. She is uniquely American and uniquely Catholic in that. It's a great story [but] it's not just a history thing, it's not like you go and you learn about George Washington or Abigail Adams...it is interesting in that same way.... and important in the history of our nation and of our Church, as a historic figure. But she's also a model for how to live your life right now in a way that George Washington probably isn't...... Not all historic figures are actual models of like 'I want to be like that person,' and she is. And what's more than that is she's not just a dead person from the past, she's alive right now in heaven waiting to pray for you... And I know that's true of any saint....but she's just like you, she knows your situation in America, in our crazy country.... live like her, know who she is, know what she was like, know what she went through.

Dilulio thought non-Catholics had just as much reason to visit the shrine.

To non-Catholics I would say this is a woman who was a leader in our country when almost every other significant woman in that period was famous because of her husband. She was not famous because of her husband, and she was not successful because of her husband, or really because of any man. She cooperated with men, with of course the priests and Bishop Carroll and so on and so forth. But she is a remarkably influential woman early in our Republic who helped our nation, helped inspire and actually build the social safety network that we're all so proud of today. And she has been largely neglected and overlooked by historians because some of them get the hibbie jibbies because she's Catholic.... Come to our living history programs, read [Catherine O'Donnell's] book, learn about her, and tell people about her. 
As we ended our conversation, Dilulio explained the interesting position religious

pilgrimage sites play within both the tourism and the Catholic world.

We try to straddle the world of both tourism and the Catholic world, and it's not always easy...And when you look at some of the things that shrines have done over the years....the actual experience...you're touching stuff, you're picking stuff up, you're kissing stuff, you're kneeling, you're doing all this interactive stuff at shrines, at pilgrimage destinations. And I go to these museum conferences, and they're like 'How do we engage people?' and I'm like 'Man, Catholics have been doing this forever.' 
BIBLIOGRAPHY

\section{Primary Sources}

Barbet, A. Guide des Pélerins. Pau G. Lescher-Montoné, 1911.

Chandlery, P. J. Pilgrim Walks in Rome: A Guide to its Holy Places. New York: The Messenger, 1903.

Clarke, Richard F. Lourdes, Its Inhabitants, Its Pilgrims and Its Miracles. With an Account of the Apparitions at the Grotto and a Sketch of Bernadette's Subsequent History. New York: Benziger, 1905.

Exercises of the Way of the Cross, as it is Performed at Jerusalem, and in the Colosseum at Rome. New York: Edward Dunigan \& Brothers, 1855.

Lambing, Andrew Arnold. Mary's First Shrine in the Wilderness. Pittsburgh: Myers, Shinkle \& Co, 1882.

Pfeiffer, James. First American Catholic Pilgrimage to Palestine, 1889. Cincinnati: J. Berning, 1892.

Raphael, John M. "My Pilgrimage to Lourdes.” The London Magazine (November 1901): 351358.

Roberts, R. Ellis. A Roman Pilgrimage. New York: Frederick A. Stokes company, 1911.

Sheehy, D. J. Notes on the Irish-Canadian Pilgrimage and Addresses. Brooklyn: Nolan Bros., 1892.

Starr, Eliza Allen. Pilgrims and Shrines. Chicago: Eliza Allen Starr, 1885.

Vetromile, Eugene. Travels in Europe, Egypt, Arabia Petrae, Palestine and Syria. D. \& J. Sadlier \& Company, 1871.

Francis, M. E. Little Pilgrims to Our Lady of Lourdes. New York: P. J. Kennedy \& Sons, 1916.

\section{Newspapers and Magazines}

America, New York, New York, 1909-1922.

Catholic Telegraph, Cincinnati, Ohio, 1831-present.

Christian Advocate, New York, New York, 1826-1973.

Denver Catholic Register, Denver, Colorado, 1913-1960.

New York Evangelist, New York, New York, 1853-1856. 
New York Times, New York, New York, 1851-present.

The Catholic World, New York, New York, 1865-1996.

The Monitor, San Francisco, California, 1858-1984.

The Sacred Heart Review, Boston, Massachusetts, 1888-1918.

\section{Archival Sources}

The Catholic University of America, The American Catholic History Research Center and University Archives, Washington, DC

A Pilgrimage to the Shrine of Our Lady of Martyrs: Auriesville, NY. 1890. 1295 NY032. Printed Ephemera.

A Shrine in the Mohawk Valley: Shrine of Our Lady of Martyrs. New York: The Pilgrim Press, 1902.

Brownson, Henry F. “The Proof of Miracles.” 1898. Ave Maria Box. BT97.B8.

Church to be Erected as a National Shrine in Honor of Mary Immaculate. 1914. DC 80. Printed Ephemera.

Correspondence, Pilgrimage to the Holy Land. 1896. ACUA 024. Box 7. Folder 2. Rev Eli Washington John Lindesmith papers.

Duggan, James. Reminiscences and Impressions of a Visit to Rome, during the Canonization of the Japanese Martyrs, A Lecture. December 18, 1862. Misc Th 2, No 6. Printed Ephemera.

Exercises of the Way of the Cross, As it is Performed at Jerusalem, and in the Colosseum at Rome. New York: Edward Dunigan \& Brother, 1855.

I am the Queen of Heaven.' The Story of 'the Chapel,' at Robinsonville. 1910. W1 188. Printed Ephemera.

Schaefer, Joseph. Devotion to the Miraculous Infant Jesus of Prague. 1898. Box 1831, 1-21, \#10 Envelope. Printed Ephemera.

Souvenir of the Golden Jubilee and Solemn Consecration of the Cathedral of the Immaculate Conception. 1902. NY171. Printed Ephemera.

Stoddard, Charles Warren. Two Celebrated Sanctuaries of the Madonna in Italy. 1906. ACUA37.42. Printed Ephemera.

Catholic Historical Research Center of the Archdiocese of Philadelphia, Philadelphia, PA 
Holy Father's Golden Jubilee, Pilgrimage to Rome and Grand Tour of Europe. 1908. P002.0496. Printed Ephemera.

Third Annual American National Pilgrimage. 1896. PO18.363. Printed Ephemera.

\section{Secondary Sources}

\section{Books}

Akagawa, Natsuko and Laurajane Smith, eds. Safeguarding Intangible Heritage. London: Routledge, 2018.

Badone, Ellen, ed. Intersecting Journeys: The Anthropology of Pilgrimage and Tourism. Champaign: University of Illinois Press, 2010.

Beal, Timothy K. Roadside Religion: In Search of the Sacred, the Strange, and the Substance of Faith. Boston: Beacon Press, 2005.

Bremer, Thomas S. Blessed with Tourists: The Borderlands of Religion and Tourism in San Antonio. Chapel Hill: University of North Carolina Press, 2004.

Buggeln, Gretchen, Crispin Paine, and S. Brent Plate, eds. Religion in Museums: Global and Multidisciplinary Perspectives. New York and London: Bloomsbury Academic, 2017.

Buggeln, Gretchen and Barbara Franco, eds. Interpreting Religion at Museums and Historic Sites. Lanham: Rowman \& Littlefield, 2018.

Cauvin, Thomas. Public History: A Textbook of Practice. New York: Routledge, Taylor \& Francis Group, 2016.

Coleman, Simon and John Eade, eds. Reframing Pilgrimage: Cultures in Motion. New York and London: Routledge, 2004.

Dolan, Jay P. The American Catholic Experience: A History from Colonial Times to the Present. Westminster: Crown Publishing Co, 2011.

Eade, John, and Michael J. Sallnow, eds. Contesting the Sacred: The Anthropology of Pilgrimage. Champaign: University of Illinois Press, 2000.

Freedberg, David. The Power of Images: Studies in the History and Theory of Response. Chicago: University of Chicago Press, 1989.

Gjerde, Jon. Catholicism and the Shaping of Nineteenth-century America. Cambridge: Cambridge University Press, 2011.

Glassberg, David. American Historical Pageantry: The Uses of Tradition in the Early Twentieth Century. Chapel Hill: University of North Carolina Press, 1990. 
Kalman, Harold. Heritage Planning: Principles and Process. New York: Routledge, 2014.

Kaell, Hillary, ed. Everyday Sacred: Religion in Contemporary Quebec. Montreal: McGillQueen's University Press, 2017.

-Walking Where Jesus Walked: American Christians and Holy Land Pilgrimage. New York: New York University Press, 2014.

Hennesey, James J. American Catholics: A History of the Roman Catholic Community in the United States. Oxford: Oxford University Press, 1983.

Kean, Hilda and Paul Martin, eds. The Public History Reader. New York: Routledge, 2013.

Kelland, Lara. Clio's Foot Soldiers: Twentieth-Century US Social Movements and Collective Memory. Amherst: University of Massachusetts Press, 2018.

Labadi, Sophia and Colin Long, eds. Heritage and Globalisation. New York and London: Routledge, 2010.

Meringolo, Denise D. Museums, Monuments, and National Parks: Toward a New Genealogy of Public History. Amherst: University of Massachusetts Press, 2012.

Morgan, David. The Lure of Images: A History of Religion and Visual Media in America. London: Routledge, 2007.

Nolan, Mary Lee, and Sidney Nolan. Christian Pilgrimage in Modern Western Europe. Chapel Hill: The University of North Carolina Press, 2018.

Olick, Jeffrey K., Vered Vinitzky-Seroussi, and Daniel Levy. The Collective Memory Reader. Oxford: Oxford University Press, 2011.

Olson, James Stuart. Catholic Immigrants in America. Boston: Nelson-Hall, 1987.

Paine, Crispin. Religious Objects in Museums: Private Lives and Public Duties. New York and London: Bloomsbury, 2013.

Pazos, Antón M., ed. Nineteenth-Century European Pilgrimages: A New Golden Age. New York and London: Routledge, 2020.

Rieger, Joerg. Faith on the Road: A Short Theology of Travel and Justice. Downers Grove: InterVarsity Press, 2015.

Shaffer, Marguerite S. See America First: Tourism and National Identity, 1880-1940. Washington: Smithsonian Institution Press, 2001.

Stausberg, Michael. Religion and Tourism: Crossroads, Destinations, and Encounters. New York: Routledge, 2011. 
Sullivan, Bruce M., ed. Sacred Objects in Secular Spaces: Exhibiting Asian Religions in Museums. New York and London: Bloomsbury Publishing, 2015.

Swatos, William H. Jr. On the Road to Being There: Studies in Pilgrimage and Tourism in Late Modernity. Leiden: Brill, 2006.

Taves, Ann. The Household of Faith: Roman Catholic Devotions in Mid-Nineteenth Century America. Charlottesville: University Press of Virginia, 1986.

Taylor, Diana. The Archive and the Repertoire: Performing Cultural Memory in the Americas. Durham and London: Duke University Press, 2003.

Tilden, Freeman. Interpreting our Heritage. Chapel Hill: The University of North Carolina Press, 2009.

Turner, Victor and Edith Turner. Image and Pilgrimage in Christian Culture: Anthropological Perspectives. New York: Columbia University, 1978.

Vikan, Gary. From the Holy Land to Graceland: Sacred People, Places and Things in Our Lives. Washington, DC: The AAM Press, 2012.

\section{Articles}

Bar, Doron, and Kobi Cohen-Hattab. "A New Kind of Pilgrimage: The Modern Tourist Pilgrim of Nineteenth-Century and Early Twentieth-Century Palestine." Middle Eastern Studies 39, no. 2 (April 2003): 131-148. doi:10.1080/714004511.

Barna, Gábor. "National Pilgrimages, Pilgrim Trains and Identity-Building." Religion, Culture, Society: Yearbook of the MTA-SZTE Research Group for the Study of Religious Culture 2 (2015): 191-212.

Bielo, James S. "Replication as Religious Practice, Temporality as Religious Problem.” History and Anthropology 28, no. 2 (March 15, 2017): 131-148. https://doi.org/10.1080/02757206.2016.1182522.

Bowman, Marion. "Railways, Rivalry and the Revival of Pilgrimage in Glastonbury, 1895 and 1897." Religion, Culture, Society: Yearbook of the MTA-SZTE Research Group for the Study of Religious Culture 2 (2015): 168-190.

Bowman, Marion, and Tiina Sepp. "Caminoisation and Cathedrals: Replication, the Heritagisation of Religion, and the Spiritualisation of Heritage." Religion 49 (March 2019): 74-98.

Cauvin, Thomas. "The Rise of Public History: An International Perspective." Historia Crítica 68, no. 68 (2018): 3-26.

Collins-Kreiner, Noga. "The Geography of Pilgrimage and Tourism: Transformations and Implications for Applied Geography." Applied Geography 30, no. 1 (2010): 153-164. 
Hendrickson, Brett. "The Interweaving of Pilgrimage and Tourism at the Santuario de Chimayó.” U.S. Catholic Historian 34, no. 3 (September 21, 2016): 127-145.

Foster, Sally M. and Siân Jones. "The Untold Heritage Value and Significance of Replicas." Conservation \& Management of Archaeological Sites 21, no. 1 (February 2019): 1-24. doi:10.1080/13505033.2019.1588008.

Kaell, Hillary. "Museums, Expositions, and Religion in North America since the 19th Century." Oxford Research Encyclopedia of Religion (September 26, 2017). https://doi.org/10.1093/acrefore/9780199340378.013.405.

Klatzker, David. "American Catholic Travelers to the Holy Land 1861-1929." The Catholic Historical Review 74, no. 1 (1988): 55-74.

Orsi, Robert. "Abundant History: Marian Apparitions as Alternative Modernity." Historically Speaking 9, no. 7 (2008): 12-16.

. "The Center Out There, In Here, and Everywhere Else: The Nature of Pilgrimage to the Shrine of Saint Jude, 1929-1965." Journal of Social History (1991): 213-232.

\section{Website Content}

“Defining Cultural Landscapes.” National Park Service. Accessed September 24, 2020. https://www.nps.gov/subjects/culturallandscapes/understand-cl.htm.

"Hopping Procession of Echternach.” UNESCO. Accessed September 25, 2020. https://ich.unesco.org/en/RL/hopping-procession-of-echternach-00392.

“Kalaupapa.” National Park Service. Accessed October 15, 2020. https://www.nps.gov/kala/learn/historyculture/na-kokua.htm.

Kinney, Jim. "Holyoke Developer Buys St. John Cantius in Northampton for \$1.6M; 23 Townhouses Planned." Mass Live. April 2, 2020. https://www.masslive.com/business/2020/04/holyoke-developer-buys-st-john-cantius-innorthampton-for-nearly-3m-23-townhouses-planned.html.

Peters, Lamonica. "Vacant Catholic Church Will Become Mosque on Buffalo's East Side." Spectrum News. February 4, 2017. https://spectrumlocalnews.com/nys/buffalo/news/2017/02/3/st--gerards--catholic-church--buffalo--east-delevan--father-mazur--muslim-mosque?fbclid=IwAR2SW4hsnSdbS97SSY7EEaJ-3sm6tlO7mUP94z3scKkoeQ5sXsBWXD-pV8.

“Relic.” New Advent Encyclopedia. Accessed September 16, 2020. https://www.newadvent.org/cathen/12734a.htm.

Roman Curia. Pontifical Council for the Pastoral Care of Migrants and Itinerant People. Vatican.va. Accessed October 20, 2020. 
http://www.vatican.va/roman_curia/pontifical_councils/migrants/documents/rc_pc_migra nts_doc_19960520_profile_en.html.

“Sacred Mijikenda Kaya Forests.” UNESCO. Accessed September 24, 2020. https://whc.unesco.org/en/list/1231.

"Sacred Sites and Pilgrimage Routes in the Kii Mountain Range." UNESCO. Accessed September 24, 2020. https://whc.unesco.org/en/list/1142.

“Sacri Monti of Piedmont and Lombardy." UNESCO. Accessed September 24, 2020. https://whc.unesco.org/en/list/1068.

Stannard, Ed. "Pain Mingles with Acceptance as Closed Catholic Churches Are Sold." New Haven Register. January 21, 2019. https://www.nhregister.com/news/article/Painmingles-with-acceptance-as-closed-Catholic-13546893.php\#item-85307-tbla-3.

Zimmer, Amy. "A Dozen Church Properties Deconsecrated by Archdiocese for Potential Sale." DNA Info. July 26, 2017. https://www.dnainfo.com/new-york/20170726/eastvillage/catholic-church-archdiocese-real-estate-sales/. 